\title{
UM ESTUDO SOBRE LIMITE
}

Dissertação apresentada ao Programa de PósGraduação em Artes, Área de Concentração Artes Visuais da Escola de Comunicações e Artes da Universidade de São Paulo, como exigência parcial para obtenção do Título de Mestre em Artes, sob a orientação do Prof. Dr. Rubens Machado.

São Paulo 


\section{RESUMO}

Objeto: estudo do filme Limite, de Mário Peixoto, Brasil, 1930, tendo, como eixo norteador, suas estruturas narrativas.

Metas: averiguar, no corpo-texto do filme, seus mecanismos de fatura e as questões estéticas e de linguagem decorrentes.

Resultados: multiplicidade de questões do cinema, da ordem da articulação dos modos de tempo e ambigüidade da natureza da imagem, onde os sistemas narrativos, engendrados pela montagem, determinam alterações no gênero de representação e na própria qualidade dessa imagem. Desdobramento em pesquisa sobre o cinema experimental no Brasil e suas formas de elaboração de sentidos.

PALAVRAS-CHAVE: Limite, Mário Peixoto, cinema experimental. 


\begin{abstract}
Subject: Study of the film Limite by Mario Peixoto, Brasil, 1930, focusing on its narrative structures.

Aims: To check, the verbal expressions of the film, its mechanisms and aesthetic form and use of "language."

Results: the variety of facets of the cinema, the order of representations of time and the ambiguity of the nature of the image, its narrative systems, put together by the assembly, will determine the differences in the type of the image representation and also the quality of this image. A development in the research of experimental cinema in Brasil and the elaboration of senses.
\end{abstract}

KEY-WORDS: Limite, Mário Peixoto, brazilian experimental cinema. 


\section{SUMÁRIO}

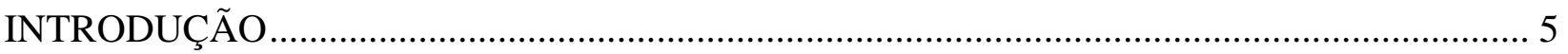

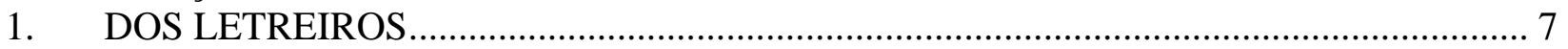

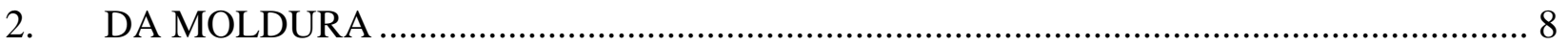

2.1. Das duas naturezas de imagem - o mítico no real.................................................................... 8

2.2. Da neutralidade do olhar - o atemporal........................................................................ 9

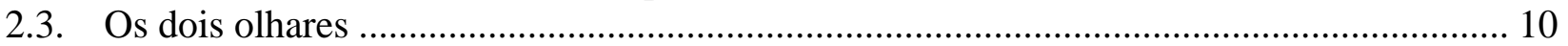

2.4. Uma história possível .............................................................................................. 12

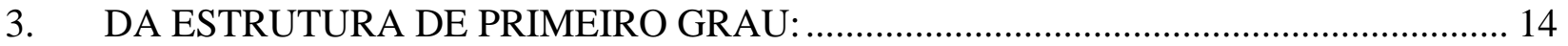

3.1. Iniciando a narrativa de primeiro grau - delimitando as personagens - da natureza da

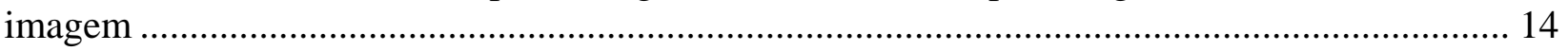

3.2. Do percurso teleológico........................................................................................................ 16

3.3. Preparando e definindo o foco narrativo - primeiro dos segmentos da estrutura narrativa

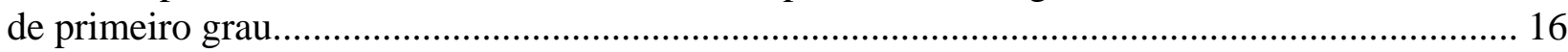
3.4. Preparando e definindo o foco narrativo - segundo dos segmentos da estrutura narrativa

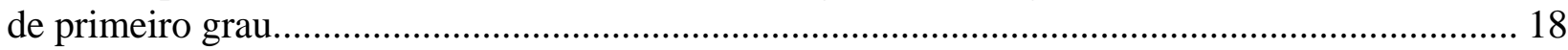

3.5. Preparando e definindo o foco narrativo - terceiro dos segmentos da estrutura narrativa de primeiro grau...................................................................................................................... 21

3.6. Preparando e definindo o foco narrativo - quarto dos segmentos da estrutura narrativa

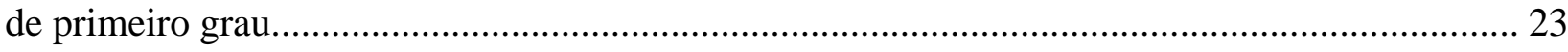

3.7. Da função rítmica ...................................................................................................... 25

3.7.1. O olhar onisciente - o anonimato (personagens) - dilatação do instante, atemporalidade

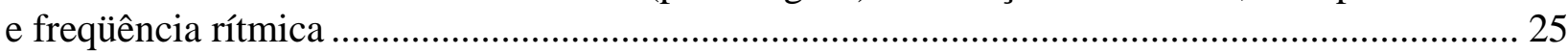

3.7.1.a. Tempo diegético - a dilatação do instante......................................................................... 28

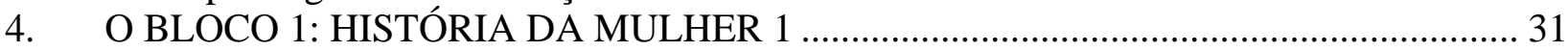

4.1. Da estrutura: justaposição, elipses e condensação................................................................ 31

4.1.a. Processando a estrutura - o olhar relativo ................................................................................ 32

4.1.b. Processando a estrutura - da câmera "relativa"....................................................................... 33

4.1.c. A caminhada - a câmera e o ponto de vista ........................................................................ 34

4.2. Repassando as diferenças com o bloco Mulher 1 - o tempo (cíclico) da repetição rituais do cotidiano - das seqüências iterativas e pseudo-iterativas ................................................ 37

4.3. O plano que deflagra - condensação, projeção e síntese da montagem - relatividade do plano 40

4.4. A evocação do lugar - o espaço como condição de vida .................................................... 43

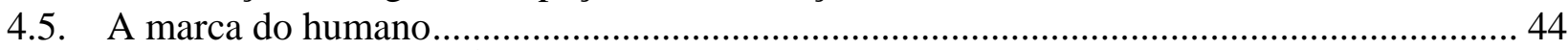

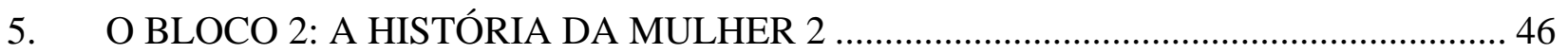

5.1. Da estrutura ............................................................................................................... 46

5.1.a. Evocação do lugar - a praia dos pescadores - equivalências entre as estruturas .................. 47

5.1.b. Evocação do lugar - o vilarejo - marcas da subjetividade na imagem e freqüência

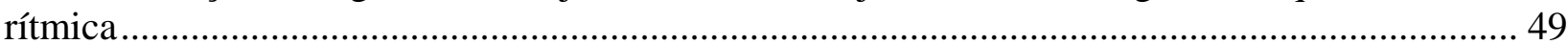

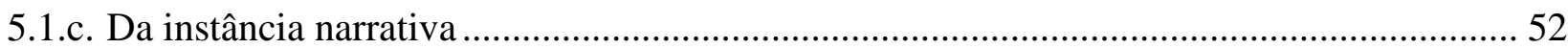

5.1.d. A passagem do tempo - o antigo e moderno - uma contradição que se insinua na forma

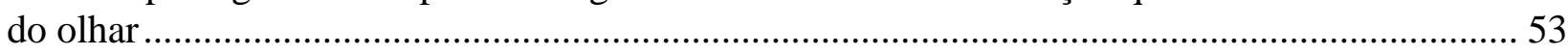

5.2. Início do desenvolvimento da narrativa - um outro cinema - relações de simetria na

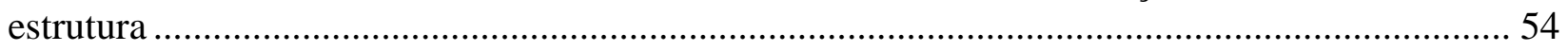

5.2.1. O outro lado do espelho - a mudança no estilo - a caminho do penhasco ........................... 56

5.2.2. Da intervenção do narrador ............................................................................................. 58

5.3. No penhasco - tão a sós, quanto num quarto de costura ..................................................... 60

5.3.1. No penhasco - tão imobilizada quanto as três personagens no barco - uma estrutura de terceiro grau - equivalências com a estrutura narrativa de primeiro grau.. 
5.4. A Figura do outro (o Homem 2) - nova mudança no estilo ............................................. 63

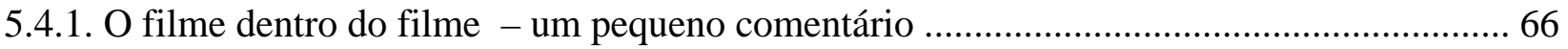

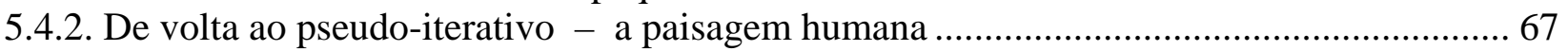

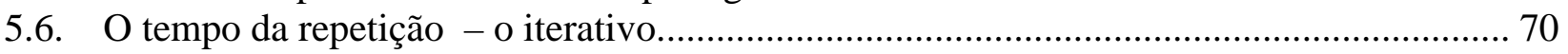

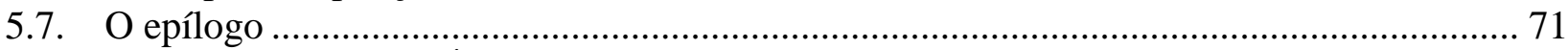

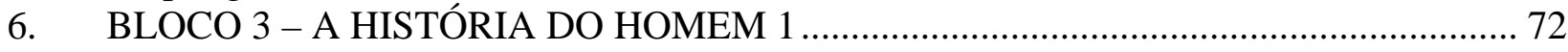

6.1. O homem, a mulher e a paisagem - o tempo passado ..................................................... 72

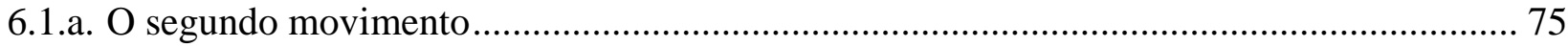

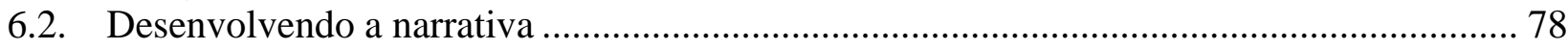

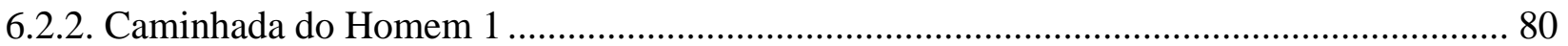

6.2.3. Retorno ao narrativo-descritivo - uma personagem misteriosa ....................................... 83

6.2.3.a. Uma composição se insinua - uma narrativa (oculta) possível ...................................... 86

6.2.3.b. A caminho do epílogo - uma outra narrativa paralela possível .................................... 90

6.2.3.c. Epílogo - partida...................................................................................................... 92

6.3. Personagens e estrutura - uma estética burguesa? .......................................................... 94

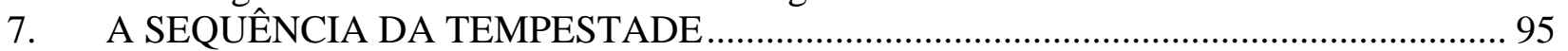

8. UMA HISTÓRIA POSSÍVEL - A AMBIGÜIDADE DA IMAGEM ............................. 98

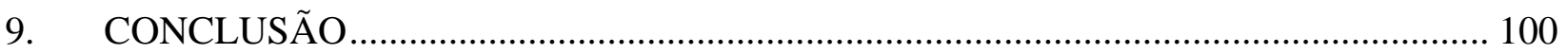

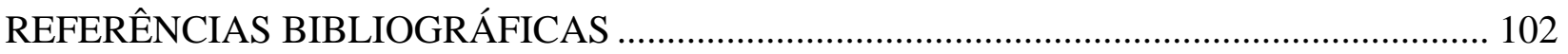




\section{INTRODUÇÃO}

Este trabalho é um estudo sobre "Limite”, o filme realizado em 1930 por Mário Peixoto e fotografado por Edgar Brazil, tendo, como eixo norteador, suas estruturas narrativas.

Falar de estruturas narrativas a respeito de um filme de linguagem poética, considerado, por muitos, como não-narrativo ${ }^{1}$ ou rítmico ${ }^{2}$, pode soar incongruente e, se na época, notícias nos dão conta de eventual perplexidade diante de sua linguagem ${ }^{3}$, hoje, na contemporaneidade, a identificação do que poderia ser considerada como uma narrativa - ou narrativas - em seu corpo, é mais óbvia.

Como sabemos, Limite é o primeiro filme, no país, a estabelecer diálogo com o que seria o cinema de vanguarda estética, no período, sintonizado com as experimentações formais mais radicais que tinham em mente a especificidade do cinema enquanto linguagem e forma de arte $^{4}$. Como tal, se cristalizou em nossa cinematografia: obra de arte única, sem precedentes no período, e que persiste, apesar de não ser mais, hoje, um consenso ${ }^{5}$.

Nos anos sessenta, diante do projeto estético e ideológico do Cinema Novo, por exemplo, como sabemos, sofreu reservas, sendo associado à idéia de filme “burguês”, formalista. Implícito à idéia, um filme mais europeu do que brasileiro ${ }^{6}$.

A intenção nesse trabalho é passar ao largo dos conceitos projetados sobre o filme e fazer uma averiguação mais próxima de seu corpo, considerá-lo enquanto texto,

\footnotetext{
1 "As imagens se concatenam mais como metamorfoses da imagem protéica do prólogo do que narrativamente" Saulo Pereira de Mello em Limite, Ed. Rocco, Rio de Janeiro, 1996, p. 34. "Fundamentalmente não-narrativo, o cenário de Limite (...) não decorre de uma história, mas diretamente do tema.”, idem, p. 93.

2 "É o ritmo que preside as cenas e anima cada imagem...", Octávio de Farias em Mapa de Limite, Inlivro, Funarte 1979, Rio de Janeiro. (intr.)

${ }^{3}$ A respeito, entrevista de Plínio Sussekind da Rocha a críticos da revista francesa L’Áge du Cinema que lhe teriam indagado se o filme "não seria antes um jogo livre de imagens e de temas, que encontramos em alguns curtas-metragens de vanguarda." . ("Mário Peixoto e Limite”, Hemeroteca Cinemateca Brasileira, D 471/5, citada em O Terceiro Olho, Francisco E. Teixeira, Ed, Perspectiva, Fapesp, São Paulo, 2003, p. 22.)

${ }^{4}$ A respeito, ver Sétima arte, um culto moderno, parte 1: "A contemplação do belo pelo cinema”. Ismail Xavier, Ed. Perspectiva, SP, 1978, e A Experiência do Cinema, org. Ismail Xavier, Segunda Parte: "A ampliação do olhar”,Graal, São Paulo, 1991.

${ }^{5}$ Glauber Rocha. Revisão crítica do cinema brasileiro. cap. “O mito Limite”. Rio de Janeiro: Civilização Brasileira, 1963.

${ }^{6}$ Glauber Rocha. Limite, Folha de S.Paulo, 03 jun. 1978, Hemeroteca Cinemateca Brasileira, 595/15.
} 
independentemente das intenções do autor; procurar, na obra, em si, seu próprio mecanismo de fatura, suas leis internas, para, a partir daí, levantar as questões que ele pudesse nos trazer ${ }^{7}$.

As figuras de linguagem abordadas por Gerard Genette em seus estudos da narrativa ${ }^{8}$, em particular, as que se referem à s relações de freqüência, no tempo, entre a narrativa e a diegese $^{9}$, foram utilizadas como instrumental de apoio ao trabalho, no sentido de facilitar a distinção entre períodos de tempo, formas de linguagem relativas à sua elaboração e designação de determinados pontos importantes na sua construção, no que se refere, por exemplo, a formas de conjugação dos tempos na narrativa (tempo passado, presente e futuro), bem como no uso das elipses.

Em seu O Olhar e a Cena, (Ed. Cosac e Naify, Cinemateca, SP, 2003), o crítico Ismail Xavier nos lembra, a cada momento, que o “olhar é construído”. Da mesma forma que Eisenstein nos assegurava que a montagem faz mudar a natureza do plano ${ }^{10}$.

Tal é, em parte, como veremos, como se processa a fluidez das imagens de Limite que, a depender da ótica e do ponto de vista determinados pelas estruturas narrativas, tem o sentido e mesmo o gênero e a linguagem das imagens com que trabalha, alterados. Assim, o que parece definitivo em um momento, em outro, aparece transfigurado em uma outra forma.

O filme se constitui de múltiplas estruturas narrativas: uma principal (a estrutura narrativa de primeiro grau), de onde se originam as três outras (estruturas narrativas de segundo grau).

De modo opcional, talvez, um tanto arbitrário, decidi por considerar, à parte, o que seria a moldura do filme (as seqüências que o abrem e que o fecham).

Partamos para a análise.

\footnotetext{
${ }^{7}$ O método não é novidade, já sendo praticado por Paulo Emílio Salles Gomes em suas aulas no Depto de Cinema, Rádio e TV, da Escola de Comunicações e Artes, USP, nos anos setenta e conforme direcionado por Ismail Xavier.

${ }^{8}$ Ver O Discurso da Narrativa, Gerard Genette, trad, Fernando Cabral Martins. Lisboa, Portugal: Assírio Bacelar, 1972.

${ }^{9}$ Idem acima, p. 113.

${ }^{10}$ Ver "Uma inesperada junção”, em A forma do filme, Serguei Eisenstein, trad. Teresa Ottoni. Rio de Janeiro: Zahar, 1990.
} 


\section{DOS LETREIROS}

A palavra "Limite", escrita no grafismo de um desenho tosco, primitivo, no qual a tinta escorre pelos contornos das letras e se derrama para baixo, transbordando pela base, surge do fundo do quadro e avança, brusca, até primeiro plano. Sua arte-final é ruidosa. Não é um expor simplesmente a palavra escrita e, através dela, o significado que denota. Ao contrário, a forma se salienta e se exibe, tecendo, desse modo, um comentário, desvelando a intenção da expressão. O desenho nos lembra um expressionismo primitivo, caboclo ${ }^{11}$, como nos letreiros dos cartazes circenses dos espetáculos de horror nas feiras de variedades no final do Século XIX ou no interior do Brasil, até mesmo nos dias de hoje. Surgida do fundo da tela, após um minuto de preto na cadência da música suave, é como um grito que irrompesse: limite. Na intenção que se insinua por detrás, no atirado brusco, através da forma que se deixa transbordar, um assombramento. No agressivo do gesto que quer impactar, um atordoamento que nos é devolvido no imediato das emoções. A idéia sentida de forma muito próxima a de um determinado estado juvenil que se recusa a aceitá-la dentro dos parâmetros do que seja natural. A emoção que se expressa é trêmula, não-domesticada, diamante não-esculpido. Limite. Podemos pensar que, se é a condição humana de se estar vivo, no caso, nos é gritada por aquele que almeja o infinito.

Já na segunda parte dos letreiros, assume-se um outro tom, mais discreto, menos eloqüente, silencioso: letras despojadas, de desenhos elementares, contornos definidos. Letreiros informativos que querem apenas apresentar, de forma objetiva, a sumária equipe técnica seguida da indicação das personagens e respectivos intérpretes. As personagens não estão nomeadas. Reduzidas ao seu anonimato, não estão sequer designadas por uma função social ou caracterização típica que as possa referir em um contexto de cunho sociológico (como era comum nos filmes da época: “a florista”, “a noiva”, “o vagabundo”, “o mendigo”, “a enfermeira” etc.). O que as define, o que as constitui, é o gênero da espécie humana a que pertencem, hierarquizadas de modo numérico, serial, moderno ${ }^{12}$ : Mulher 1, Mulher 2, Homem

\footnotetext{
11 Expressionismo caboclo: expressão cunhada pelo cineasta Rogério Sganzerla, nos anos sessenta, para designar o desajeitamento no cinema brasileiro ao copiar os modelos importados de matrizes estrangeiras. Por ingenuidade no processo, exagerar nos traçados da forma de modo desajeitado, tosco, resultando numa espécie de "expressionismo caboclo", em referência paródica ao expressionismo no cinema alemão,).

12 , O serial, o numérico, como índice da modernidade, de acordo com Walter Benjamin. Seus estudos sobre Baudelaire, a descrição das personagens de uma vida moderna, as passagens parisienses na segunda metade do Século XIX, as grandes concentrações urbanas. As alterações nos sentidos do tempo na era pós-industrial, a ruptura das narrativas diante da experiência do choque na vida moderna. O fenômeno de ruas, até então nomeadas, personalizadas, passarem ao anonimato e à frieza do numérico, à indiferença, o corpo destituído de sua alma. Ver, a respeito, os estudos que compõem O Cinema e a Invenção da Vida Moderna, org. Leo Charney
} 
1, Homem 2. Em essência, o feminino e o masculino despojados de sua nominação. Ao final de tudo, veremos que existe uma profunda coerência entre essa maneira de proceder nos letreiros (a combinação dos dois estilos) e o princípio estético que rege a construção do filme como um todo.

\section{DA MOLDURA}

\subsection{Das duas naturezas de imagem - o mítico no real}

É somente após a música nos colocar em um determinado ritmo, um andamento e uma atmosfera que se aproxima à da delicadeza, e dos letreiros que mesclam os dois estilos de desenho - o que se quer expressivo e o natural, o gritado e o discreto, o que quer mostrar e o que se mostra, o tosco e o elegante, o primitivo e o moderno - é que temos a primeira imagem: uma colina, a pedra nua ocupando a base inferior do quadro tomado, em sua maior parte, pelo vazio de um céu claro, a claridade do sol mais intensa brilhando difusa por trás das nuvens. Sobre o topo da colina, pousam urubus. O plano introduziria um espaço diegético em ambiência realista (plano filmado em exteriores, em locação), à luz do dia, natural, não fossem os elementos escolhidos em angulação que favorece a construção mítica: câmera de baixo para cima, em contra-plongée, que isola, no recorte do quadro, o topo da colina de pedra nua contra o vazio do céu onde o clarão do sol ofusca por trás das nuvens; a depuração dos elementos naturais, telúricos, que escolhe como motivos visuais: pedra, ar, sol. São detalhes colhidos na natureza de forma a transferir a categoria do mítico a um plano que é, em sua origem, realista.

A música prossegue e acentua a experiência do transcorrer do tempo. Aos poucos, em lenta fusão, rompendo o espaço da diegese que ora mal se insinua, surge um outro plano, este agora de natureza francamente alegórica, no sentido de ser uma imagem produzida artificialmente para traduzir uma idéia anterior, um pensamento por detrás, uma imagem oculta que fosse a mais profunda, a mais próxima à verdade que se quer mostrar. A luz dirigida, recortada, destaca a figura no escuro do quadro: trata-se do rosto de uma mulher, que 
viremos a conhecer como a MULHER 1 (Olga Breno). Mas não se encontra ainda caracterizada como tal, pelo menos no plano do verismo. Seu rosto e parte do pescoço destacados pela luz, os cabelos penteados de modo sóbrio, composto, a se confundir com o negro que a envolve em moldura, seu olhar levemente inclinado para frente, de confronto com a câmera, distanciado, compõem, aqui, mais uma figura do que uma personagem. Cercando o rosto da mulher, vindo por detrás, envolvendo-a, os punhos de um homem que a rodeiam e que, por sua vez, encontram-se algemados. Essa imagem, iluminada pelo negro do escuro, é ostensivamente produzida, artificial. Quer explicitar a alusão a uma outra idéia por detrás, fornecer uma síntese imagética do próprio tema do filme. Através de uma fusão, somente os punhos algemados do homem passam a ocupar todo o quadro, destacando a idéia do aprisionamento, do enredamento mútuo.

\subsection{Da neutralidade do olhar - o atemporal}

Aos poucos, igualmente por uma nova fusão de planos, a imagem dos punhos algemados começa a desaparecer. E, coincidindo com sua posição no quadro, à altura dos punhos que vão se esvaecendo, a imagem em detalhe de dois olhos de mulher, as sobrancelhas finas, escuras. É a mesma luz natural de uma locação em exterior, difusa, clara, sem contraste acentuado entre o claro e escuro, em ambiência realista, como era a luz do plano da colina com os urubus. Pela semelhança de linhas e traços, reconhecem-se os dois olhos da mulher que compõe a figura da alegoria, a Mulher 1. São olhos que não piscam, e que surgem em plano de detalhe num enquadramento frontal e "sangrado", de forma a preencher todo o quadro. Os cenhos franzidos, as sobrancelhas finas, negras, a câmera à altura média dos olhos. Por contigüidade e semelhança de luz e registro, este plano pode estabelecer com o plano da colina dos urubus uma relação de homogeneidade espacial, podendo estar, ambos, inseridos em um mesmo ambiente, num mesmo universo diegético, de exteriores (e não interior, como no plano alegórico), de luz clara. A imagem alegórica seria assim inserção de comentário extra-diegético que o narrador estaria a proceder em meio à seqüência que estivesse a nos narrar, à guisa de comentário, como é procedimento típico na montagem conceitual de Eisenstein em seus estudos acerca do discurso do monólogo interior, da linguagem do fluxo de consciência. 
Mas há, aqui, o detalhe do enquadramento, neste novo plano: fechado, não nos deixa referências de espaço possível. E há a altura da câmera que, pelo fato de estar no nível dos olhos, à meia-altura - com eles, estabelece uma posição de absoluta neutralidade emotiva. Esses olhos fixos, e que não piscam, traduzem, por sua vez, um olhar refletido, interiorizado, mortiço. Ao contrário da mesma mulher na imagem alegórica, não é um olhar de confronto: é um olhar que se volta para dentro, não para o mundo exterior.

Ele persiste na tela por um longo tempo, no andamento da música cadenciada de Satie, até que nova, lenta fusão faça esses olhos submergirem na imagem das águas da superfície do mar/oceano que vêm a ocupar todo o quadro. Na superfície aquosa, vemos a vibração da luz do sol que cintila numa miríade de pontos luminosos, como num espelho líquido a refletir a luz, para que depois, novamente, gradualmente, vejamos essas gotículas de luz se decompondo, se dissolvendo, outra vez, através de nova sobreposição de imagem, para que ressurja o plano dos olhos da Mulher que, se submersos estavam, retornam à superfície, reafirmando sua presença, vindo de camada anterior, como se um esquecido (submerso) retornasse pela memória.

\subsection{Os dois olhares}

Na relação causa-efeito promovida pela montagem entre o plano dos olhos da Mulher 1 e o plano da superfície das águas, poderíamos ter dito: a Mulher contemplava o oceano. Mas os efeitos de transposição de um plano para o outro, por fusões longas e de modo gradual, onde um, lentamente, cede ao outro, criando, dessa forma, o efeito de submersão, de camadas que se sobrepõem onde a anterior, no entanto, não desaparece definitivamente, permanecendo justaposta, nos lança dois outros temas: no nível do anedótico, da narração ${ }^{13}$ propriamente dita, da história possível que se conta, a oposição entre as personagens da Mulher-Ser-Humano - Histórico-Relativo (olhos) e do mar (natureza-a-histórica). A mulher (aqui designada pelos seus olhos) é engolfada, submersa pelas águas do oceano, o que, de certa forma, sinaliza para o final do filme, uma tempestade que vem para fazer submergir, para cobrir.

\footnotetext{
${ }^{13}$ Narração designando o conteúdo do discurso. Narrativa como o discurso em que a narração se manifesta. A narrativa pressupõe o relato de eventos acontecidos. História e narração só existem, pois, para nós, por intermédio da narrativa" Ver O Discurso da Narrativa, Gerard Genette. trad. Fernando Cabral Martins. Lisboa, Portugal: Assírio Bacellar, 1972.
} 
A se considerar os sentidos engendrados pela lógica da montagem associativa e rítmica, que é a se proceder nesta seqüência, um outro tema se mostra: um aquoso imemorial (sem tempo) que contem os olhos (a visão), designativos da mulher, do vivo, do humano, do corpóreo, ainda que mortiço, pois os olhos não piscam, ainda que sem alma, portanto, esquecido, como se no plano do inconsciente, mas que ali continua e, por vezes, irrompe, voltando à tona da superfície, como será no filme todo: um passado a que se regressasse, se dissolvesse, se dissipando no presente. O tema da memória, enfim, de um efêmero secular e histórico (corpóreo, que nos é dado pelos olhos, a visão) submerso sob o oceano, território onde e para quem o tempo não existe.

Os olhos da Mulher 1, em detalhe, duram, na tela, um tempo igualmente longo para, logo a seguir, serem substituídos, em fusão novamente, pelo quadro mais aberto desta mesma Mulher, mas agora vista de cima, em plongée, olhando para baixo, pensativa e, pelo detalhe furtivo do contorno de uma borda de espaço, situada em um local determinado, enquanto território físico, geográfico, num tempo histórico qualquer, não mais atemporal (mítico), como poderia sugerir o plano detalhe dos olhos com seu recorte de absoluto isolamento.

Neste novo plano, em plongée, vê-se a mulher de rosto inteiro (não mais apenas seus olhos), na mesma luz natural de ambiente externo, com os cabelos levemente desarranjados, de corte curto. Ela está, ao que parece, sentada, pois a vemos em primeiro plano, o rosto e os olhos inclinados para baixo, o ângulo, da perspectiva superior favorecendo o tom reflexivo na expressão. O quadro, agora, não é mais na perspectiva frontal, mas diagonal, evitando-se, portanto, o confronto com a câmera, restaurando-se a idéia da quarta parede a separar o mundo da diegese, em sua autonomia e leis próprias, do nosso mundo, mundo dos espectadores.

A alteração da perspectiva frontal para a diagonal é fundamental, pois acentua a diferença entre a natureza dos dois planos: agora, no quadro mais aberto, a mulher é vista inserida em um contexto dotado de vida própria que parece existir paralela e naturalmente a transcorrer diante da câmera, em um fluxo temporal e horizontal, um tempo cronológico, com autonomia de existência diante dela que assume, desta forma, a função da moldura de uma janela invisível para o mundo que independe de sua existência, como quer o uso da câmera no cinema clássico. Ao mesmo tempo, não é mais a exposição de um fluxo de pensamento, mas sim a de personagens imersos em situação. O narrador, nesse momento, se elide a favor do mundo das personagens que quer relatar. 
A fusão que faz a passagem entre os dois planos - o Plano Detalhe dos olhos em sua neutralidade atemporal reforçada pela meia-altura da câmera e pelo recorte do enquadramento em perspectiva frontal, e o Plano em Plongée da mesma Mulher 1, vista agora em quadro mais aberto e em perspectiva diagonal - é longa, deixa por alguns instantes os dois planos justapostos, sugerindo, desta forma, a seguinte relação: a Mulher 1 está olhando-se a si mesma, ou então - o que talvez seja o mais interessante pensar - rememorando-se a si mesma em um instante passado, a partir de um outro tempo alhures. Seus olhos recortados no detalhe, sem referência de espaço possível, ocupando a tela toda, estão dotados de uma atemporalidade quase mística, como se pairasse vindo de um outro espaço (nível de leitura vertical), de um outro tempo (nível de leitura horizontal), superior (espacial) ou ulterior (temporal) a ela mesma colocada nas circunstâncias do humano: os olhos observam, de cima, de um plano supra-terrestre, ou lateral, de um plano extra-quadro, ela mesma situada, agora, na condição terrena, geográfica (e histórica, portanto).

Um olhar onisciente sobre aquilo que é colocado em circunstância.

\subsection{Uma história possível}

Podemos dizer que, a partir daqui, inicia-se propriamente a diegese do filme, sua narrativa ficcional e projetiva. A fusão que deixa por algum momento as duas imagens justapostas na tela (os olhos da mulher e ela mesma vista em plongée em um espaço demarcado geograficamente - na circunstância do humano e, portanto, histórica) sugere que, a partir daqui, tudo começa a vir à tona como se fosse uma vasta lembrança, uma memória de algo que ficou submerso e que começa a vir novamente à superfície, a partir da perspectiva dessa mulher. De onde se pode concluir que todo o filme, a partir dessa estrutura narrativa que ora se inicia, uma grande estrutura de primeiro grau, pode ser visto como se uma grande rememoração dessa personagem que se coloca, a partir desse momento como narradora, no caso, intra-diegética, pois pertence ao universo da ficção que nos é contada (ou, no caso, rememorada).

Até este momento, tivemos uma espécie de moldura que voltará no final do filme, de modo a fechar a estrutura geral em um jogo de simetrias nos seus internos espelhamentos. Essa moldura obedece à lógica de uma montagem associativa, não-narrativa, pois segue o fluxo de uma consciência totalizante, omnisciente, em movimento, que expõe antes a lógica 
de um suceder de imagens que se associam e se ressoam internamente (tal como um pensamento que se formula, em processo) ao invés da narração de eventos em sucessão cronológica em relação linear de causa-e-efeito. O que temos, portanto, é o acompanhamento da exposição do fluxo interno de um pensamento, - (e não a narração de uma intriga de natureza literária) -, onde se justapõem as seguintes unidades:

1. Abertura: urubus na colina, sol-nuvem.

2. Inserção à guisa de comentário emblemático do tema do filme: imagem alegórica da mulher e do homem enredados.

3. olhos da mulher (atemporal) que são submergidos no oceano e reaparecem à tona de seu fundo (os olhos submersos) - voltaremos ao tema (a história submersa no oceano que não tem tempo).

4. olhos da mulher (atemporal) interiorizados que trazem à tona imagem dela mesma colocada em circunstância, em território geograficamente delimitado, em um tempo localizado, histórico, o que demarca, mais apropriadamente, como dito, o início da narrativa, relato de eventos no tempo.

Nesta moldura, tivemos até aqui, em diálogo bastante sintético, dois tipos de procedimentos na elaboração da imagem: uma artificial, produzida, de teor alegórico que remete a uma idéia anterior, por detrás; outra de luz natural, capturada em ambientes locais, exteriores, de teor realista, mas que, através dos recortes dos enquadramentos e angulações, colhe ou lê no natural da paisagem do mundo, aspectos atemporais, míticos (planos detalhe dos olhos mortiços que não piscam, a superfície das águas cintilantes do mar/oceano, colina dos urubus). O princípio que rege a ligação entre os planos é por associação, por justaposição (colina-pedra-urubus à mercê da luz do sol por trás das nuvens x mulher - homem - algemas / olhos da mulher x superfície das águas do oceano refletindo a luz do sol / olhos da mulher $\mathrm{x}$ ela mesma em situação histórica, terrena (passagem da moldura para o início da narrativa). A partir de agora, iniciamos a narrativa, a primeira grande estrutura de base que gerará as três outras de segundo grau que dela emanam e que são passadas em outra dimensão de tempo: secular e humano. 


\section{DA ESTRUTURA DE PRIMEIRO GRAU:}

Das funções narrativas e dos sentidos engendrados pelo uso da câmera na decupagem da realidade, pelo estilo de montagem e modo de construção das personagens.

\subsection{Iniciando a narrativa de primeiro grau - delimitando as personagens - da natureza da imagem}

O plano do detalhe dos olhos da Mulher 1 sobreposto àquele em que a vemos em um local situado, vista em plongée (de uma câmera alta, da perspectiva de um olhar colocado em nível superior) é, portanto, o que marca o início da estrutura de primeiro grau do filme: os olhos introspectivos, colocados numa dimensão atemporal, na duração lenta da fusão, parecem mesmo rememorar, trazer de volta, à tona, acontecimentos passados em outra dimensão, temporal.

A mulher que se vê, a partir desta perspectiva superior, - e que é ela mesma, a Mulher 1 - está sentada em um barco, pequeno, de madeira. Visto de cima, o barco, que é estreito, tem a proa, pontuda, direcionada para o canto superior direito do quadro, assemelhando-se à ponta de uma seta, oca em seu interior, como uma casca - a forma de um esquife, pontudo em cujo interior, está a Mulher: de costas, em nível abaixo ao nosso, os braços fortes, nus, semi-esticados, as mãos apoiadas no banco onde está parada, sentada, a postura ereta em confronto com o mar.

Seu figurino se decompõe em duas partes: a blusa branca sem mangas de tecido simples, e a saia preta (poderemos ver, depois, que apresenta detalhes de bolinhas minúsculas brancas sobre o preto numa estampa que lembra - se não é o mesmo - vestido em que ela aparece em outro momento do filme, em seu passado), rasgada e que deixa ver parte do saiote, perdido já o sobretudo de um conjunto desfeito. Os cabelos em desalinho. Não está só no barco. Em novo plano, ligeiramente mais aberto, igualmente em plongée, sentado no meio, o corpo dobrado sobre si, prostrado, vencido, um homem (o Homem 1, Raul Schnoor): o remo caído entre os braços, a roupa igualmente em farrapos, um rasgo na camisa, nas costas, as mangas que foram compridas perdidas, apesar do cinto preto que a mantém para dentro das calças, composta. A câmera corrige acentuando o remo caído na água do mar. Novo corte: atrás, caída na popa, deitada, desfalecida, vestida em um conjunto preto, inteiriço, de modo a lhe cobrir todo o corpo (ao contrário da Mulher 1), apesar de uma das mangas longas rasgada (notaremos depois, mas agora, este detalhe não aparece), a gola a lhe fechar o pescoço. Seu 
corpo, de preto, estendido no fundo do barco estreito, filmado em plongée, reforça a sinistra imagem de uma morta em um esquife ${ }^{14}$. Um outro plano, agora mais aberto, revela o conjunto da situação: o barco isolado no meio das águas do oceano, as três figuras das quais, na verdade, agora só podemos ver duas, apesar de termos em mente que ali, na popa, caída, encontra-se a outra mulher, a de preto. A luz difusa, a posição hierática das três figuras paradas - na proa, a Mulher 1, ereta, confrontando o mar; no meio, o homem inclinado sobre si mesmo e, atrás, em off - não vemos, mas sabemos - a Mulher 2, caída (as três figuras remetendo à imagem de um único ser desdobrado nas formas da representação das três principais fases da condição da vida, perfazendo a idéia do ciclo.) - a mise-en-scène enfim, acrescida dos elementos telúricos reduzidos à unidade elementar (como no plano de abertura do filme: água, sol, ar) e da própria figura mítica do barco (o barco que conduz, através das passagens, correspondentes aos ciclos ou estágios possíveis, e que habita, simultaneamente, metade acima da superfície (razão) e metade abaixo (nas profundezas do esquecido, do inconsciente, do apagado) do mar/oceano, faz com que, novamente, o plano de natureza realista adquira sentido simbólico. Essa simbologia nasce de uma imanência do real e a imagem que se vê, pelo senso de realidade nela contido, pela atmosfera evocada pela luz clara e difusa, alude, de modo indefinido, a um sentido outro, não explícito como na alegoria, mas que manifesta a evocação de uma familiaridade longínqua (a "floresta de símbolos familiares”, de que nos falava Baudelaire). Nasce, para se retomar parte do pensamento de André Bazin, da imagem como registro de um pedaço da realidade vivida, de um tempo congelado a ser revivido a cada instante em que se o projeta novamente, do cinema como reprodução realista do mundo. Aquela idéia de que a realidade esteve lá, a câmera registrou o tempo em que ela ocorreu, o vestígio do real ficou impresso no negativo, assim como na mente dos olhos que a filtraram. e que, no caso de "Limite", surge acrescida do fato de, pela moldura, pela luz, pela combinatória fortuita e inusual de determinados elementos, fazer com que se vislumbre o simbólico no real. A aproximação aqui, utilizando como paradigma outros autores do período, não se faz tanto com a intenção do mostrar ou significar (Eisenstein), mas no de se deixar mostrar ou no de se apreender ou ler na natureza certos símbolos ocultos (Murnau). Reforça-se a tendência do estilo em que a elaboração do mítico ou do poético se faz, substancialmente, através de uma técnica de filmagem realista, ou seja, apoiada numa origem, nos lugares que filma em sua luz natural.

14 Octávio de Farias referem-se à imagem do esquife. 


\subsection{Do percurso teleológico}

Esta estrutura de primeiro grau ${ }^{15}$ divide-se em quatro segmentos principais distribuídos ao longo do filme e cumpre percurso teleológico. Cada um deles apresenta indícios pontuais que sinalizam para a eminência de um fim: o isolamento das três personagens no meio do oceano, o barco à deriva; o vento que, segmento a segmento, se evidencia, agitando os cabelos, anunciando a tempestade; o precário de suas provisões que se acentua (alguns biscoitos, o balde da água para se beber vazio, a sede, a água do mar que começa a entrar pelas frestas abertas na madeira do barco que começa a ceder...). No final, ocorre a tempestade. Antes dela, já encontramos um processo de dissolução nas próprias personagens: o Homem 1 atira-se ao mar, na tentativa, talvez (a iniciativa não é muito convincente), de alcançar o que parece ser um barril ao longe, e não regressa. Afunda-se sob a superfície das águas: a câmera chega a apanhar o borbulho na tentativa de captar suas profundezas. A Mulher 2 é repelida, empurrada para fora de campo pela Mulher 1 e, a partir daí, não a vemos mais. Vem a tempestade e leva tudo ao fundo. Essa estrutura de primeiro grau, portanto, é a que se configura como eixo condutor do filme, que nos apresenta a situação dramática com suas personagens em uma determinada circunstância, trabalhando, a partir daí, a evolução dos temas na perspectiva de um fim: uma tempestade, a caminho, que, no final, se realiza.

\subsection{Preparando e definindo o foco narrativo - primeiro dos segmentos da estrutura narrativa de primeiro grau}

Uma segunda função encontrada em cada um dos quatro segmentos, pelos quais essa estrutura se distribui no todo, é igualmente a de estabelecer o foco narrativo a ser seguido por cada um dos três relatos e, igualmente, pelo bloco narrativo referente ao desenlace (a tempestade), com os quais, na diacronia do filme, interagem e dialogam. Assim, no primeiro dos segmentos, observamos vir a primeiro plano a personagem da Mulher 1 - que já "abrira” o filme na imagem da alegoria e na seqüência de sua moldura - que é a narradora intradiegética que rememora toda a grande narrativa que começamos a testemunhar a partir da transição da moldura para ela (a estrutura narrativa de primeiro grau) e que, no primeiro dos

\footnotetext{
${ }^{15}$ Estrutura de primeiro grau - segundo a definição de Genette - p. 5 subtítulo: preparando o foco narrativo.
} 
relatos (primeira das estruturas narrativas de segundo grau), será igualmente sua narradora (duplamente narradora, portanto: rememora-se, rememorando-se a si mesma contando sua vida passada ao Homem 1, aqui, no caso, transformado em narratário ${ }^{16}$ ).

A Mulher 1 é a que vem romper a imobilidade hierática com que as três personagens surgem no início - (ela parada, ele caído, a outra, desmaiada): introduzida em um plano onde surge de costas, favorecendo sua posição de confronto com o mar, suas mãos dirigem-se para os cabelos que remexe, numa gesticulação nervosa. Manifesta uma inquietude, um desespero diante da situação. Quando o campo de visão se abre, mantendo-se a mesma perspectiva, as linhas de fuga apontam para ela que tem sua cena de ação: vira-se, apanha uma lata, abre-a, procura por outra, mexe... Sentado à direita, de costas, encurvado, prostrado, o Homem 1 compõe a moldura que orienta o foco de atenção para ela. A Mulher 1 é a personagem que se movimenta: encontra os biscoitos, oferece ao homem. No descascar uma laranja, corta-se com a faca, lava a ferida no sal das águas do mar. Ao contrário do que ocorre com os outros dois: ele, com a aparência de desânimo, nos ombros caídos para frente, na barba por fazer, na expressão de resignação e desistência que se acentua no rosto e no olhar para baixo; ela, a Mulher 2, deitada, frágil, toda vestida de preto, desfalecida, como morta. O plano que se volta para o Homem 1 e para a Mulher 2, de preto, caída ao fundo, é aquele em que a Mulher 1, em off, a mão entrando em campo, lhe oferece o biscoito. É, portanto, passivo, diante da Mulher 1, quase que um contracampo, respondendo a uma ação deflagrada por ela.

Um outro plano nesta mesma direção, é para acentuar a própria presença da Mulher 2: o olhar do Homem 2 serve como mediação para se chegar à evidência da Mulher 2, apresentando-a, dessa forma, como personagem. Através do ato de seguir a direção do olhar do Homem 1 para o corpo caído da Mulher 2 (o que, por outro lado, estabelece um elo entre os dois, uma atenção dele na sua direção), desmaiada ainda, demarca-se a nova personagem, reafirmando-a em cena (a Mulher 2 já fora vista, uma vez, deitada, no fundo do barco).

Neste plano, o Homem 1 é visto na mesma expressão de abatimento, passivo, comendo do biscoito providenciado pela Mulher 1, para quem, logo a seguir, a decupagem retorna a atenção: a Mulher 1está de costas para a câmera, em 3/4, olhando para o seu dedo ferido.

\footnotetext{
${ }^{16}$ Narratário, de acordo com Genette.
} 
A montagem insinua o isolamento entre eles: o Homem 1 olha para a Mulher 2, que está desmaiada; a Mulher 1 olha para sua própria ferida. Em seu auto-isolamento, cada uma das personagens conquista sua própria autonomia. Não há coadjuvantes.

O terceiro dos principais planos voltados para o Homem 1 corresponde a uma subjetiva do olhar da Mulher 1 que, filmada novamente de costas, em 3/4, em plano próximo, faz movimentos de oscilações de desespero com a cabeça para voltar o olhar na direção dos seus dois, aparentemente circunstanciais, companheiros de viagem, uma vez que, ao que tudo indica, não encontramos, na tela, indícios de qualquer vínculo de intimidade entre eles, como se amigos fossem, ou parentes ou casais instituídos. Na virada, os cabelos revoltos vem a primeiro plano. Toda a decupagem, portanto, é orientada no sentido de se voltar para a Mulher 1 que, ademais, como visto, é a personagem ativa. É somente após a termos visto empreender seu primeiro gesto com os movimentos nervosos de mexer nos cabelos diante do infinito do mar que os cerca e com o qual se defronta, que o Homem 1, mesmo em movimentos pesados, de desânimo sempre, procura remar (e logo, novamente, desiste). É também um plano detalhe dos seus cabelos revoltos, de parte de sua cabeça, quem dá a partida para o plano de transição para o primeiro recuo no tempo: o plano da beirada do barco com vista para a superfície das águas do mar que ondulam. O movimento da ondulação da superfície das águas do mar, no filme, é fundamental para que se faça a passagem, trazendo à tona, gradativamente, como uma imagem fugidia que, aos poucos se esclarece, no tempo do resgate da memória, a imagem do passado aos pouco retornando e se definindo: nós a vemos atrás das grades, em contra-plongée, introduzindo-se assim a primeira das estruturas narrativas de segundo grau, aquela que reconstitui seu tempo passado, o da Mulher 1.

\subsection{Preparando e definindo o foco narrativo - segundo dos segmentos da estrutura narrativa de primeiro grau}

No segundo segmento desta estrutura de primeiro grau, temos o desvio do foco narrativo na direção da Mulher 2.

Inicia-se no retorno ao tempo zero da narrativa, à situação das três personagens no barco, à deriva, no meio do oceano, após o final do relato da Mulher 1. Vê-se esta, ainda, terminando de falar, a câmera em contra-plongée acentuando sua garganta, seu pescoço, eliminando parte de seu rosto - a parte dos olhos - de campo. 
A ênfase é na palavra, no ato da fala. E, no entanto, fosse um filme sonoro, não teríamos necessidade de ouvir o que dizem. As palavras que ela enuncia, nesse momento, em si, não nos interessam, o fundamental tendo já acabado de ser visto. O anedótico não é o assunto, as impressões, os semblantes, a atmosfera dos ambientes, as atitudes ou as nãoatitudes, no caso, o que sentem, como sentem, são os dados a que se atém. Em vários momentos, em Limite, veremos que as pessoas falam, mas não sentimos necessidade de saber ou de entender o que falam. Sentimos que o que está em jogo passa pela atmosfera, pelos lugares vividos por aquelas pessoas, por tardes e momentos a sós, no meio de uma natureza descuidada, como veremos, à revelia, como aquelas pessoas. O fato de que alguém conta alguma coisa para o outro: nos gestos físicos e movimentos reduzidos a unidades elementares, nos ombros caídos de desarmamento, no despojamento, naquilo que lhes é tido como essencial. O que move são os semblantes, não é a palavra, não é o texto. E, talvez pela posição quase sempre inclinada dos corpos, a sensação de que há um peso que paira sobre aquelas personagens. Trata-se do estatuto da imagem. Se não ouvimos o que eles se dizem, compreendemos, temos uma intuição.

O Homem 1, sempre reclinado, tem os olhos voltados para os dois gravetos que manipula entre os dedos. A câmera sempre em plongée. Ele se volta, o olhar por sobre os ombros, o ângulo destacando os cabelos bastos e revoltos, o vento sacudindo as mechas na fronte, e a câmera, novamente, como a montagem anteriormente, volta a acompanhar a direção de seu olhar para enquadrar, atrás, deitada, desmaiada, a Mulher 2.

A montagem segue a direção do olhar do Homem 1 e, detalhando, aponta para uma panorâmica descritiva que percorre o corpo da Mulher 2, desfalecida. Repete-se, novamente, o já visto, - agora, acrescido do detalhe do movimento da panorâmica descritiva da câmera o que reafirma o peso da personagem feminina, a possível ligação entre ela e o Homem 1 e, especialmente, o fato de que é, portanto, através do olhar deste Homem 1, que a Mulher 2 começa a ganhar corpo nesta narrativa. O que insinua a relação de dependência e fragilidade da Mulher 2 em relação ao Homem 1.

Através da câmera em plongée, da perspectiva de um narrador extra-diegético, (pois o enquadramento é distanciado, a câmera colocada na "terceira pessoa”, num olhar que pretende dar conta do conjunto, de “cobrir” o mundo), ciente de tudo, contaminado pelo olhar da narradora intra-diegética, a Mulher 1, a partir de uma dimensão atemporal (o plano atemporal, em detalhe, dos olhos da Mulher 1), rememora-se um relato onde a atenção é voltada para a Mulher 2, mediada pela direção do olhar do Homem 1 que é quem conduz, 
neste momento, o sentido da montagem: pelo corte, vemos descrito o olhar do Homem 1 percorrendo o corpo da Mulher 2 desfalecida.

À medida que ela desperta, a vemos, gradualmente, ocupar o espaço, vir a primeiro plano, centralizando, aos poucos, a narrativa: olha na direção do mar - e a câmera acompanha a direção. Em desalento, deixa o biscoito sobre o banco; vemos, sentado, o Homem de costas - e a câmera faz uma panorâmica para a lata de sua provisão de água: seca, vazia. O plano seguinte nos mostra ela, a Mulher 2, sentada, o corpo um pouco caído, estática. Próximo, a lata de água vazia. A montagem estabelece a relação de que, o primeiro momento em que se revela o dado da falta de água para beber, vem na perspectiva, na ótica, da Mulher 2. Seu olhar detalha atentamente, com pavor subseqüente, um dos primeiros sinais da eminência de um fim. A perspectiva do olhar da Mulher 2 é a do aterrorizado. Para ela, o mundo se configura como uma queda para o vazio, em abismo. Os dois planos do filme que se evidenciam como pontos culminantes na estrutura, pontuando, em sua geografia, no vértice, são o seu olhar de desespero do alto de um penhasco e os olhos aterrados, na beira de cima da murada do barco, o vento fustigando os cabelos, a pupila arregalada, fixando o mar de onde o Homem 1, após, nele, ter se atirado, não volta. Expressão do terror, do medo, da fragilidade. Seu figurino fechado, cobrindo-lhe quase todo o corpo, com os rasgos, um colar de onde pende um crucifixo e um pequeno gancho, faltando-lhe o sapato em um dos pés. A Mulher 2, de preto, aproxima-se do Homem 1, olha na direção da Mulher 1, que é vista em um plano, de costas, contra o mar (a posição de confronto com o mar); a Mulher 1 vista pela perspectiva da Mulher 2 que mede, dessa forma, a distância. É pelo olhar da Mulher 2 que vasculhamos, pela primeira vez, em detalhe, o real peso da situação: o mar que os cerca, a falta de água. Sua mão busca o ombro do Homem 1, mas ele a afasta. A Mulher 2 vem a primeiro plano e ganha corpo através das cenas de seu passado que, ainda que incompleto, cheio de lacunas e, por isso, rarefeito, recompõem, nos limites do possível, - (para parodiarmos o tema) - sua identidade. A Mulher 2 será o foco narrativo do segundo retorno no tempo do filme.

Assim, novamente, é através do sentido da direção do olhar das personagens, do olhar que depositam sobre alguma coisa, olhar que se volta para o mar, que se direciona para o outro que está sempre, ou de costas, ao lado, o olhar interiorizado, reflexivo, como se um véu lhes nublasse os olhos, o rosto inclinado para baixo, que temos a narrativa aproximando-se, pouco a pouco, da perspectiva do olhar dessa Mulher 2, passando a ser ela, nesse momento, o foco narrativo do relato e, posteriormente, a própria narradora intra-diegética - e foco narrativo, sendo, portanto, também a narrada - do segundo relato no filme. 


\subsection{Preparando e definindo o foco narrativo - terceiro dos segmentos da estrutura narrativa de primeiro grau}

Logo após o término do relato da Mulher 2, a Mulher 1 é a primeira que aparece, sentada, levemente encurvada, mas não é encurvamento de desânimo: as mãos juntas, estendidas através dos braços esticados, os cotovelos apoiados nos joelhos, a posição a transforma mais em uma narratária, aquela que ouve, em um momento relembrado por ela mesma num tempo posterior. Há o detalhe do braço do Homem 1, igualmente apoiado sobre sua própria perna, em posição de inclinação, também narratário, ouvinte do que acabamos de ver: aqui, o detalhe da mão caída, solta, deixa transparecer o desânimo. A Mulher 1 é ainda a que procura se mexer, tenta remar mais uma vez, resiste. Percebe-se da inutilidade de sua tentativa. Pára em desânimo. É um dos poucos, raros, contra-plongées nesta seqüência, e, no caso, serve para marcar, pontuar a pausa - seu rosto inclinado, no contra-luz, contra o céu ao fundo - marcar a consciência do inútil, a desistência. Ao lado, sentados, lado a lado, o Homem 1 e a Mulher 2 compartilham da mesma expressão de desânimo expresso nos olhares que lhe enviam... A Mulher 1 olha para o mar, lança fora o remo e tenta, ainda assim, debruçando-se, deitada, por cima da proa do barco, mover-se, através das águas, com os braços. A Mulher 1 é a que se debate, a que se recusa à derrota. A ela, justapõe-se, novamente, o Homem 1; é quando o foco se desvia: parado, imóvel, imerso e isolado em seus pensamentos, movimenta, entre os dedos, dois gravetos. Olha para eles absorvido. Sobre o detalhe dos dois gravetos sendo manuseados, aos poucos, vemos sobrepor-se uma imagem paradisíaca, difusa, de um lugar ao longe, uma praia, uma orla, os morros ao longe, baixos, indefinidos numa mancha cinza, as águas claras avançando em rasgo no canto direito, penetrando a orla, as duas pernas do casal de amantes. Somos penetrados através dos olhos do Homem 1, na sua atenção para os dois gravetos que, manuseados, trazem à memória um lugar distante, uma praia... e mergulhamos no passado desse Homem 1, tal como relembrado pelos olhos "neutros" da Mulher 1.

A história do Homem 1 nasce de um auto-isolamento, uma impenetrabilidade e sentido do fechamento, de recusa (ele afasta a mão da Mulher 2 que lhe pousa sobre o ombro, rejeitando a possibilidade do contacto), ao contrário das narrativas das mulheres cujo movimento é no sentido de dentro-para-fora. O terceiro segmento tem desdobramentos e diálogo com o núcleo da estrutura de segundo grau que lhe corresponde, ocorrendo em 
montagem paralela com aquele. Vemos a primeira parte do relato deste Homem e, a seguir, voltamos novamente ao presente, à situação do barco, onde o presenciamos movendo seus lábios, como se estivesse a contar. A câmera corrige para a Mulher 2, sentada ao seu lado, a mesma posição de abatimento; por corte, salta-se para a Mulher 1, na proa, também olhando para ele, sempre em plongée; e, novamente, a decupagem nos faz retornar ao Homem 1 que olha para baixo, a angulação a salientar sempre seus cabelos revoltos pelo vento, e, através, desta vez, da direção de seus olhos, e não dos da Mulher 2 (como fora no segundo segmento, foco narrativo na Mulher 2), temos, uma vez mais, intensificando o crescendo dramático, o segundo sinal que mostra a água do mar invadindo o barco pela fresta rompida.. Ao lado, o detalhe do pé nu da Mulher 2.

Neste pequeno interregno, estabelecido pela estrutura de primeiro grau que retorna, temos ainda, no mar, o plano à distância do barco, onde vemos a Mulher 2 achegar-se mais próxima ao Homem 1, ao lado do qual já se encontrava sentada, como quem lhe pedisse amparo. A Mulher 1, da mesma maneira, também se aproxima de ambos, mantendo-se, porém, no vértice do triângulo, demarcada sua diferença dos dois. Mas, todos os três, mais juntos, constituindo o pequeno núcleo no barco e que, aos poucos, por fusão, tende a se dissipar, a se dissolver sob a superfície das águas do mar que tomam todo o campo e do fundo da qual torna a emergir, mais uma vez, a paisagem longínqua da orla marítima, sob o céu, desta vez, nublado, vazia, do passado do Homem 1 que retorna, em seu segundo movimento, em sua segunda parte. O Homem 1 aparecerá, novamente, comandando sua narração, no barco, no terceiro pequeno retorno deste terceiro segmento da estrutura de primeiro grau: após ter contado de como soube, pela boca do próprio marido, da lepra que acometia sua amante. Vemos então, no presente, no barco, as outras duas mulheres se afastarem, numa reação instintiva, e ele próprio levar o lenço à boca e esfregá-lo, numa expressão de nojo. O medo do contágio mobiliza parte dos acontecimentos que seguem. Há, portanto, aqui, um desenrolar em paralelo entre os dois tempos, as duas estruturas e, nesse desenrolar, acentuam-se as diferenças entre a Mulher 1 (dinâmica) e o casal formado pelo Homem 1 e Mulher 2 (desânimo). Mas é a figura do Homem 1 quem dá a voz, a explicitação dele enquanto narrador se faz em paralelo ao episódio que conta. 


\subsection{Preparando e definindo o foco narrativo - quarto dos segmentos da estrutura narrativa de primeiro grau}

No quarto e último segmento desta estrutura, o foco narrativo irá para o desenlace: a tempestade que se anuncia, a eminência do fim. O tema do balde seco, vazio, é retomado. Pelo gesto de passar as mãos nos lábios secos, percebe-se que a Mulher 1 sente sede.

O balde, seco, vazio.

A Mulher 1 avista algo na linha do horizonte, no nível da superfície das águas do mar.

O Homem 1 levanta-se, em reação, para se atirar ao mar, na tentativa, talvez, de alcançar o objeto visto.

É a Mulher 1 quem o induz a isso. A Mulher 2 tenta segurá-lo.

Os dois olham, indecisos, na direção da Mulher 1.

Vemos, então, a Mulher 2 retirar suas mãos, recolhê-las, esfregá-las, como se quisesse limpá-las, na bainha do vestido.

Como se hesitasse...

O gesto de tibieza da Mulher 2, mediante a submissão ao julgo do olhar da Mulher 1, certamente, contribui para o movimento do Homem 1 que, "liberado", atira-se ao mar, e morre por isso.

A Mulher 2, em sua fragilidade, é o contraponto da Mulher 1: há momentos em que a omissão instintiva é o que caracteriza seus movimentos de giros em falso, de tentativas que não consegue levar adiante, sua infelicidade enredada no horizonte de impossibilidades que se coloca. A Mulher 2 é, também, o medo. Como dito, é empurrada para fora de campo, pela Mulher 1.

Os segmentos acima, como visto e reiterado, preparam e introduzem o foco narrativo a ser desenvolvido em cada uma das estruturas narrativas de segundo grau, correspondentes, em linhas gerais, à História da Mulher 1, História da Mulher 2 e História do Homem 1. 
Após o salto do Homem 1 para o vazio, a Mulher 2 dirige, novamente, o olhar para o detalhe da água do mar que, cada vez mais, invade o barco. O olhar da Mulher 2 polariza o sentimento da fragilidade, do desespero, do sentimento de impotência e da procura do outro como refúgio.

A Mulher 1, por diversos indícios, só pode contar com ela mesma.

Progressivamente, pela montagem, a perspectiva dos enquadramentos começa a se direcionar novamente para a Mulher 1: a vemos repelir a Mulher 2 com agressividade, voltarse e se deixar abater pelo desespero.

Os cortes sucessivos, aos poucos, passam, do plongée ao contra-plongée, seu rosto contra o céu, o contra-luz de modo a colocar uma linha de sombra na base inferior do quadro, os olhos fechados, o céu acima.

E depois, por um corte seco, a câmera à meia-altura, no nível médio dos olhos, na posição de confronto diante - pelo corte, vemos - da linha do horizonte, a superfície das águas do mar em movimento.

Este plano, a câmera à meia-altura dos olhos, do rosto da Mulher 1, - (em Primeiro Plano) - o rosto de modo a tomar todo o quadro, a cabeça entre as mãos, os olhos abertos, fixando a câmera, é o primeiro, no plano do realismo, localizável no tempo e no espaço, a estabelecer uma analogia com o plano "atemporal" do detalhe dos olhos, na moldura de abertura do filme. Ele anuncia um outro que virá, no final, com carga de estranhamento, pois surgirá, após a tempestade, fixo, paralisado, os fios dos cabelos molhados caídos, como algas, sobre o rosto desta Mulher 1. O plano é fixo e, nele, a face da Mulher 1 parece congelada, os fios de cabelos molhados escorridos sobre o rosto.

A meia-altura da câmera nesses planos, a frontalidade do olhar da Mulher 1 para ela, é o que ajuda a fechar, juntamente com o plano da figura alegórica já mencionada, a moldura e, com ela, a narrativa aberta com o plano em detalhe dos olhos que não piscam.

Diante do rosto da Mulher 1, a cabeça entre as mãos, o oceano, uma massa líquida imemorial, a ocupar quase todo o quadro; na faixa superior, atravessando, o pedaço claro do céu. Começa a tempestade, concluindo um dos movimentos do filme: os olhos da Mulher 1 diante do mar. 


\subsection{Da função rítmica}

A terceira função dos segmentos da grande estrutura narrativa de primeiro grau presente no filme é a rítmica.

O sentido de unidade por trás da proliferação de métodos e estilos que nele encontramos deve-se, em muitos aspectos, à sua pontuação rítmica. O sentido de unidade rítmica nasce da idéia da repetição. Uma determinada unidade que retorna, uma, duas, três ou mais vezes, na freqüência, ordem e tempo respectivos, e que, nas relações de semelhanças e diferenças, no contraste entre os opostos que promove entre as partes no conjunto, estabelece um eixo de referências quanto à sub-divisão de pulsões num determinado fluir de tempo.

No caso de Limite, as repetidas vezes em que as cenas dessa estrutura de primeiro grau retornam e estabelecem a relação de familiaridade necessária entre as partes, permitindo a compreensão formal e afetiva de um todo, é pela imposição de um sentido de tempo dilatado, que é dado pela montagem, e pelo uso quase exclusivo dos plongées (à exceção de três planos por motivos funcionais ${ }^{17}$ ), a câmera a partir da perspectiva de um nível superior de altura em relação ao objeto, opção que é seguida como fundamentação nos segmentos que compõem esta estrutura de primeiro grau, servindo os contra-plongées, raros, como já visto, apenas nos momentos distintivos, para destacar instantes de tomada de consciência vindo pelo abatimento momentâneo, no caso da Mulher 1, ou acompanhado pelo sentimento do terror, no caso da Mulher 2, ou ainda, pela prosaica intenção de associar o ato da fala da personagem com o enquadramento dos órgãos emissores e de ressonância: boca e garganta.

\subsubsection{O olhar onisciente - o anonimato (personagens) - dilatação do instante, atemporalidade e freqüência rítmica}

Os ângulos em plongée, se relacionados com o plano detalhe dos olhos mortiços da Mulher 1 que compõem a moldura de abertura e encerramento do filme, olhos que não piscam, neutros e atemporais, que pairam sobre tudo, reforçam a idéia de que existe uma

\footnotetext{
${ }^{17}$ Os três contra-plongées na estrutura narrativa de primeiro grau: na Mulher 1, no momento em que ela acaba de narrar sua história (a câmera aponta para sua garganta); na Mulher 1, em pé, no barco, quase no final, quando ainda tenta remar mais uma vez, mas se detém, e olha desanimada, dando-se conta da inutilidade de seus gestos (para marcar tomada de consciência da personagem sobre sua real situação; o Primeiro Plano da Mulher 2, os olhos aterrados, assomando sobre a beirada do barco, ao se dar conta da morte do Homem 1(para definir seu estado de horror).
} 
perspectiva a partir de um ponto de vista ideal, centralizador e unificador, totalizante no sentido de cobrir o todo, o conjunto da visão-mundo; o olhar de um narrador onisciente, que constrói e controla o mundo de sua diegese, que tudo sabe e organiza, o olhar do demiurgo, do iluminista. Este olhar, impregnado de um sentido metafísico, pela montagem de tempo dilatado e pelo enquadramento, sobreposto à posição em plongée de câmera sobre as personagens, é o que define, no fluxo narrativo, a presença de um olhar onisciente, uma omnisciência, que paira sobre aquelas personagens.

Aquelas personagens não têm nome. Também não se identificam de modo preciso com alguma caracterização de ordem sociológica ou tipológica definida. Não se pode apreender pela sua imagem, por exemplo, sua profissão. Não são tipos regionais. No caso do Homem 1 e da Mulher 2, sua tipologia tende mais a um padrão de caracterização que segue modelos genéricos de referências universais do que regionais, brasileiras, típicas de uma localidade específica. O Homem 1, pelo corte dos cabelos, moderno, as mechas alongadas, serpenteadas pelo vento, pelos trajes, calça, camisa, cinto, lembra um tipo urbano, mas “urbano” é um termo genérico, vago. Vago, como é sua identidade. O Homem 1 pode corresponder a um protótipo de ideal masculino: porte atlético, magro, alto, uma elegância natural, discreta. A Mulher 2, como já visto, frágil, os gestos contidos, receosos, as maçãs do rosto salientes, o olhar que vasculha o ambiente com medo: mede situações, olha, se dá conta, aos poucos, aproxima-se num apelo. O figurino cobre-lhe quase todo o corpo, é inteiriço no seu preto. É um conjunto de golas, com adornos. Rasgado. Lembra atriz de filme brasileiro do período, uma atriz de cinema de gênero. Ambos, não deixam a desejar quanto ao que seria o protótipo de um casal de estrelas em uma produção de Adhemar Gonzaga, no período, ou mesmo de Humberto Mauro.

Já com a Mulher 1, as coisas se passam diferente. Já vimos seu figurino decomposto, sua saia rasgada que, no final, ver-se-á reduzida a uma tira, o saiote, a blusa sem mangas. É um figurino que deixa ver pedaços do corpo que é maciço, roliço. A Mulher 1, cujos gestos são intempestivos, a qual reage fisicamente à situação - faz tentativas, procura, fere-se etc. revela um senso do pragmatismo que, feminino, tem atitudes do masculino - é a personagem ativa, a que conduz - seu rosto de traços não tão demarcados, as linhas suaves lembrando, levemente, a face imberbe do adolescente, os cabelos de corte curto, a deixar as orelhas à mostra (ao contrário dos cabelos da Mulher 2). Os pedaços do corpo da Mulher 1 atribuemlhe sua consistência carnal, corpórea, seus gestos intempestivos, não programados, sua “rudeza”, sua origem. Possui o senso da sobrevivência, do imediato. Não é reflexiva, reage 
por instinto. Os outros dois configuram os modelos ideais de personagens oriundos de uma cultura burguesa, adaptáveis a um gênero dramático. Reflexivos, contidos, discretos, interiorizados, estilizados. São personagens e também são “idéias de personagens” e, nas seqüências mais radicais quanto ao modo de representação, chegam a ser "desenhos de personagens”, com veremos nas cenas onde o Homem 1 aparece caminhando no terceiro dos grandes flashbacks do filme. São idealizados.

O que chama a atenção, neste filme, nesta época e no cinema brasileiro, é a gestualização e interpretação dos atores: na tendência, exagerados, teatrais, melodramáticos; aqui, limpos, polidos, contidos, discretos ${ }^{18}$. Gestos estudados. A personagem da Mulher 1 é a que polariza com os outros dois: intempestiva, pragmática, no barco, é a que se movimenta com freqüência, - (procura por comida entre as latas, tenta remar, corta-se com uma faca, etc.) - em oposição aos outros dois: o olhar voltado para baixo, interiorizados, resignados. Grosso modo, podemos identificar no Homem 1 e na Mulher 2, características de personagens de origem burguesa, urbana, cosmopolita. E na Mulher 1, personagem de origem popular.

O que os une são os sinais do rasgado, de corrosão das vestes, trazendo a idéia de algum enfrentamento brutal acontecido, a sobrevivência a algum naufrágio, um primeiro embate do qual saíssem ainda com vida e que a narrativa não parece interessada em explicar. Se têm traços da modernidade, pelo vestuário de época, pelos gestos contidos, o olhar de expressão distanciada e melancólica, no caso do Homem 1 e da Mulher 2, pela virilidade no feminino no corte dos cabelos curtos, na sua postura de independência, no caso da Mulher 1, esses traços apresentam-se em meio a uma atmosfera de destroço, de coisas rasgadas, aos frangalhos, em ruínas.

A câmera em plongée acentua essa pequenez humana diante do infinito do mar que as rodeia e da imensidão que paira abaixo de sua superfície que contem sua memória, a memória daquelas pessoas. E há o tempo dilatado de cada plano, como se quisesse prolongar ao máximo a duração de cada momento, no instante em que dura. A câmera quer reter aquelas pessoas, reter o instante.

\footnotetext{
${ }^{18}$ Atores discretos, Saulo Pereira.
} 


\subsection{1.a. Tempo diegético - a dilatação do instante}

Se pensarmos no tempo diegético do filme em seu conjunto, de toda esta estrutura de primeiro grau que é a base de sua grande narrativa, observamos que ele é extremamente curto. O tempo diegético de Limite é o momento dos três náufragos no barco, perdido no meio do oceano, antes da tempestade. Momento que é dilatado ao máximo, permanecendo no estado da suspensão. É nesse estado de suspensão, de interregno, de imobilismo, que o passado vem à tona. O tempo de Limite é o tempo morto em que nada, fisicamente, ocorre. Tudo já ocorreu, restando apenas ruminações, rememorações e digressões. A tempestade no final vem para encobrir tudo, levar de retorno ao esquecimento, ao não-tempo. Esse instante de suspensão, dilatado ao máximo, é feito pela duração dos planos onde, para cada gesto, cada rosto, cada detalhe, cada movimento, a câmera parece querer se deter na atitude de uma contemplação de quem deseja reter as coisas até a consumação de cada tempo particular e único completado. É essa dilatação, portanto determinada pela montagem, que corrobora igualmente na instauração dessa temporalidade que é, antes de tudo, interior, muito próxima a uma quase "atemporalidade", na medida em que os momentos parecem destacados do contexto a que pertencem, ilhados, para se absorverem em si mesmos.

Um tempo de alheamento, de distância diante do mundo exterior, aquele que poderia nos devolver o sentido de uma história vivida no plano do coletivo, do social, enquanto processo. Acentua-se, no filme, dessa forma, a rejeição a uma estética do realismo, malgrado o fato, como aqui já bastante afirmado, de ter sido todo rodado em locações, com a luz natural.

No filme, uma vez que aquilo que é visto não pressupõe a idéia de um processo em andamento e, portanto, mutável, mas de uma condição que existe como de natureza dada, condição da existência humana, a preocupação em reconstituir uma continuidade de ação no plano cronológico e físico em relação de causa e efeito não existe. O interesse está em saber presentificar e pontuar a condição e o estado de coisas dessas personagens no momento em que acontecem, na duração e intensidade de seu tempo interior, expressando, desse modo, a atmosfera desses momentos. Pouco importa o antes e o depois, mas o presente no instante em que ocorre.

O presente, impregnado do passado. A experiência do estar, impregnado de narrativas de eventos passados a serem evocadas. No final das contas, tudo o que lhes resta. 
O plongée (olhar superior a observar o humano), a dilatação do tempo (estado da suspensão), a indefinição aparente das personagens, o isolamento do espaço que é mítico (água, sol, céu, ar, nuvens), compreendendo uma delimitação que tende ao circular (tudo gira em torno do barco), impõe à estrutura um ritmo (e um tempo interno) que é, ele próprio, o da suspensão: entre dois tempos, o ido e o a vir, o devir. O tempo da espera. A cada momento que voltamos ao tempo desta estrutura, o tempo zero da narrativa, voltamos à mesma cadência dessa suspensão, escandida, de modo a dissolver as outras narrativas encobertas, deixando delas seus vestígios, como os pontos de luz que brilham refletindo rastros dos raios solares sobre a superfície das águas. Assim como o tempo mítico tende a absorver o tempo daquilo que foi histórico, secular, efêmero, esquecível, assim como as notas da música de Eric Satie, que pontua toda esta estrutura e a comenta, tendem a brincar com a idéia de dissolução de uma escala tonal de sete notas e criar uma série de impressões fugidias, que brincam enquanto formas, como pretende a música impressionista. É o que dá o ritmo, a cadência e o andamento do filme: dilatação, suspensão, repetição, freqüência, dissolução... no cíclico e no atemporal.

Ater-se ao instante dilatado, sem a conexão de causa e efeito, destacando o momento para torná-lo espesso em sua própria ontologia, obedece a uma perspectiva idealista onde se subentende a idéia de uma essência a ser buscada. Como dito e visto, procura se reter a imagem de cada instante na intensidade de sua duração. A omnisciência do olhar em plongée e a dilatação temporal criam a sensação de que tudo é dado como uma condição. Há a presença de um olhar determinista sobre os eventos que ocorrem como fatos já consumados. O olhar é onisciente, pois, projetado de um tempo posterior, pós-morte, - o plano detalhe dos olhos que não piscam da Mulher 1 - rememora aquilo que foi acontecido. Assim, cada lembrança que ocorre, e que experenciamos no tempo presente, é, na verdade, instância passada, já ocorrida. O futuro existe para ser lembrado, pois já ocorrido na mente de quem tudo rememora. O que ocorre já foi escrito, já estava escrito. Em Limite, nesta estrutura narrativa de primeiro grau, as coisas nos são dadas como condição e estado de coisas estados de alma - como se dados da natureza e não como processo (histórico, em transformação). Tudo é fatal, tudo é determinado. Tudo é limite.

O uso da câmera alta nessa estrutura de primeiro grau que expressa essa consciência onisciente que tudo pretende saber e ser, totalizante, pressupõe uma idéia de unidade por trás. Trata-se de uma consciência ulterior no tempo (portanto, onisciente de tudo o que é simultâneo não apenas no espaço, mas no tempo) ou extra-diegética e geradora do universo a partir da perspectiva unívoca e onipresente do extra-campo . Imbui-se da idéia da onipotência 
do pensamento humano como paradigma na compreensão dos fenômenos. Esse olhar onisciente corresponde à concepção clássica, antiga, do mundo, o olhar que pretende conter o todo, a natureza como expressão do divino, a arte como cópia, ilustração e reprodução de seu universo e suas leis. Daí, como já dito, a opção radical pelo plongée em toda essa estrutura e, paradoxalmente no caso, pela perspectiva em diagonal, o olhar do ator não confrontando a câmera, mas em obliqüidade em relação a ela, colocando uma relação de autonomia e independência dos eventos diante dela, janela invisível para o mundo, a partir da perspectiva do ponto de vista ideal que almeja a onisciência sobre o mundo.

O Plongée, no filme e, em particular, nessa estrutura, acentua a presença de um olhar que contem o conjunto da situação e é determinista. Enfatiza a postura de prostração e de impotência das personagens e, portanto, o sentimento de fatalidade diante da atmosfera que se lhes abate. Como um destino, irrevogável. Mais que a tempestade que se anuncia e que, de fato, fisicamente, ameaça as personagens, o que mais os paralisa, o que mais os abate é a atmosfera, o clima, um sentimento de melancolia e prostração.

E do sentido da inutilidade de qualquer ação diante de tudo. A imaginação, mais do que a realidade, é o que os paralisa.

O olhar, nesta estrutura narrativa de primeiro grau de Limite, é da ordem de um olhar antigo.

O corpo do filme será, desta forma, composto por três recuos no tempo (três flashbacks), a partir desta estrutura narrativa de primeiro grau, o grau zero da narrativa maior, três recuos que darão conta de partes do passado de cada uma dessas três personagens. Esses passados evocados, que reconstituem parte da identidade dessas pessoas não explicam necessariamente, no plano do anedótico, dentro de uma linearidade do antes e do depois, do porquê delas estarem ali, juntas, numa mesma circunstância. Retrospectivamente, são recomposições de experiências passadas, de acordo com a linguagem da memória, feitas de justaposição de momentos que surgem em blocos, na evocação sujeita às livres associações afetivas de cada um. Priorizam acontecimentos singulativos que foram fixados pela experiência emocional dessas personagens e que retornam evocados pelas contingências do estado do atual. 


\section{O BLOCO 1: HISTÓRIA DA MULHER 1}

\subsection{Da estrutura: justaposição, elipses e condensação}

O que nos chama a atenção como procedimento técnico neste primeiro bloco da estrutura de segundo grau, é a montagem que se opera por condensação narrativa e síntese, deixando entrever elipses de tempos e ocorrências.

Se naqueles anos, conforme assinala Ismail Xavier, qualificava-se o cinema como a arte do subentendimento, chamando a atenção para a natureza metonímica de sua linguagem, onde a mente do leitor e espectador tende a completar com sua dose de imaginação e elaboração de sentidos, a partir dos elementos contidos no filme, as lacunas subentendidas entre os fatos ou eventos mostrados, Limite, e vamos ver que não somente neste bloco, é a aplicação prática do conceito. O filme, como veremos, é todo cheio de lacunas, de veredas, lugares, pessoas e narrativas elididas, apagadas, que, objetivamente, não vemos, mas cuja sombra se fazem presentes ${ }^{19}$.

A proliferação de elipses no tempo e no espaço, atendo-se aos momentos tomados em seu isolamento e que, justapostos, provocam na mente do espectador o efeito retroativo de sua visão sobre o acontecido, faz com que, num lapso, um novo dado contamine a visão sobre o visto, transferindo as informações, projetando as cargas afetivas e, num processo de condensação, levando à elaboração e criação de novos sentidos sobre aquilo que já era predeterminado.

Grosso modo, da mesma maneira em que a estrutura narrativa de primeiro grau dividese em três segmentos principais, cada um deles alternando-se com os três respectivos recuos no tempo, além da quarta que, como vimos, remete ao desenlace, ao desfecho e ao epílogo (a tempestade, e a última imagem da Mulher 1, só agarrada a uma tábua, no meio do oceano, seguido pela sua dissolução nas águas do mar e pelo plano final dos urubus), podemos encontrar aqui, de forma equivalente, também uma divisão em três partes principais que se justapõem à maneira de um "hai-kai” e que nos levam, por outro lado, em nossa mente, a recompor um trajeto, um processo:

\footnotetext{
${ }^{19}$ Ver Ismail Xavier, Sétima Arte: Um culto moderno.
} 
1. Momento de ruptura da Mulher 1 de um homem que tenta detê-la pelo braço / $\mathbf{1}$ a. caminhadas da Mulher 1;

2. Tempo de parada desta mulher em um vilarejo onde teria se dedicado a serviços de costura para fora / 2 a. Notícia do jornal anunciando "fuga de mulher da prisão” que recoloca níveis de leituras possíveis das imagens até aqui vistas (e fazem subentender uma elipse: uma nova partida da Mulher);

3. Evocação de imagens de um vilarejo no ermo que teria sido deixado para trás, vilarejo cujas imagens de desolação contagiam e que configuram o mundo daquela mulher, no passado, mundo do qual quis fugir.

\section{1.a. Processando a estrutura - o olhar relativo}

A primeira imagem que começa a se definir aos poucos, emergindo novamente, pelo efeito da fusão, por detrás do longo plano do ondular das águas do mar vistas através das bordas do barco, será a do rosto da Mulher 1, atrás das grades de uma janela. A altura da câmera, até aqui, vista prioritariamente em plongée (olhar que quer dar conta de um todo a partir de um ponto de vista e de uma perspectiva ideal e unificadora) passa para uma contraplongée (demarcação de um outro ponto de vista onde se está numa perspectiva mais parcializada, que não quer dar conta do conjunto). Essa imagem, da Mulher 1 atrás das grades de uma janela, nos remete à imagem alegórica do início do filme, agora porém em registro realista, da perspectiva da experiência no mundo. Surge e se impõe aos poucos, como vinda de um passado distante, de outro tempo. Nada indica que aquelas grades se refiram às de uma cela de prisão como, posteriormente, seremos levados a crer. A rigor, na construção da imagem, as grades podem ser as de uma janela de residência comum, malgrado o fato da posição da mulher - (por trás das grades, as mãos segurando as barras firmemente, vista em contra-plongée, de baixo para cima, e com o olhar direcionado para baixo, evitando o confronto direto com a câmera), - nos darem a impressão, senão de um aprisionamento no sentido literal, um aprisionamento no sentido figurado, de exprimir uma determinada condição existencial, um estado de alma, de sentimento (o sentir-se presa ). 


\section{1.b. Processando a estrutura - da câmera "relativa"}

O senso de ruptura formal fará a introdução do bloco e teremos, nele, um procedimento de estilo comum aos outros dois que recompõem os tempos passados. A câmera que, em toda a estrutura de primeiro grau, é contemplativa, estática, cobrindo o universo de uma perspectiva onisciente que pressupõe um ponto de vista ideal de observação (os plongées), assume agora uma posição restritiva nos enquadramentos e posição, na medida em que se assume como da perspectiva de um olhar humano em situação e em circunstância, um olhar subjetivo, que pode se fixar em detalhes de atenção, omitindo outros do campo de visão. Portanto, de perspectiva relativa e não totalizadora.

Esse assumir limites orientados pelas perspectivas de um ponto de vista escolhido entre outros - implicada na presença de uma subjetividade que é “relativizadora” diante dos eventos - por outro lado, nos traz a autonomia da câmera diante daquilo que mostra. Da passividade, assumirá o direcionamento de um olhar que se deslocará movido por pontos de interesse, pontos de atenção (câmera ativa e não passiva), aqueles que são fixados instantaneamente para serem lembrados por uma memória (processada pela montagem) que não poderá jamais compreender o todo, limitando-se à relatividade própria da perspectiva de um olhar humano colocado em situação. Um câmera opaca, que se faz ver enquanto instrumento de mediação. Inquieta, na mão(e não no tripé), assumindo-se enquanto tal, irá se revelar como o gesto nervoso do pincel nas mãos de um pintor, na tentativa de captura dos gestos, do movimento, da luz. A panorâmica abrupta resvala pela parede, até a porta de madeira rústica, fixando na maçaneta para onde se direciona a mão de um homem, homem cujo rosto não vemos, que a abre e entra por ela. É pelos detalhes que nos chamam a atenção que visualizamos, e recompomos em nossa mente, o conjunto. São eles que orientam a recomposição dos eventos em nossa mente. Quando o homem entra, a câmera, agora transformada em personagem (metáfora do olhar de quem conta a história ou de quem a ouve, ou ainda, do olhar do espectador), abaixa até o nível do chão e é dali, surpreendendo os sapatos do homem que entra, no nível do chão, que nos faz presenciar os acontecimentos.

O homem entra. A câmera poderia entrar com ele, mas não o faz. Permanece parada diante da porta, agora, fechada. Demora-se um longo tempo sem que possamos testemunhar o que se passa naquele interior, seja casa ou prisão. 
A câmera aguarda. Só depois é que, pelos pés, captura-se a Mulher saindo, seguida do Homem que procurará retê-la pelo braço. A câmera suspende na captura desse gesto, as duas mãos do Homem tentando reter o braço da Mulher que se desvencilha num gesto brusco. Ela rompe. Ela parte. Não vemos o rosto do homem e tão pouco mais o da Mulher, nesse momento. Apenas, pelos pés e pelas mãos e braço, é que vemos o momento da ruptura. A câmera volta à janela, desta vez, vazia: a Mulher 1 se foi.

\section{1.c. A caminhada - a câmera e o ponto de vista}

Uma sucessão de seis longos planos-seqüência poderão nos dar conta dessa partida da mulher.

Planos 1 e 2: Dois planos com a câmera à altura do nível do chão, de modo a sublinhar fachadas de casas corroídas pelo tempo, em perspectiva, na direção da linha de fuga, as paredes descascadas, envelhecidas - lado a lado - de modo a ocupar todo o terreno, cada uma delas, as portas e janelas estreitas, de madeira, fechadas, dando direto para a rua; o mato comendo o passeio de pedra, perdendo-se no meio do chão de terra batida. Nos dois planos, no vazio de uma paisagem de ruelas de vilarejo abandonado - ninguém à vista - vê-se a Mulher entrando em quadro e caminhar na direção da linha de fuga até quase se perder de vista. A lentidão do caminhar, a luz clara do sol, o vazio da paisagem que se impõe e é atravessada pela personagem (casas de fechadas envelhecidas, calçadas desertas comidas pelo mato), aumentam a impressão de desolação, de ruína, de abandono, de partida.

Planos 3 e 4: No terceiro e quarto planos que seguem, a câmera assume um contraplongée radical, vertical, como se na perspectiva de uma câmera subjetiva, da personagem que caminha - ao contrário dos plongées utilizados na estrutura narrativa de primeiro grau, que tendem a dar a impressão de um narrador onisciente a cobrir os três personagens no barco. A câmera desliza contra a beirada de um telhado colonial recortado contra o céu e, depois, contra a luz do sol que brilha e nos cega através das folhagens da copa das árvores. Ela nos tenta dar a impressão subjetiva ao invés da ilustração da ação da caminhada. A rigor, poderia ser o ponto de vista da personagem que caminha, no caso, a Mulher 1.

Plano 5: No quinto plano, a perspectiva do olhar se bifurca: é o olhar de um narrador extra-diegético, já que a câmera apanha a personagem - a Mulher 1 - em seu vestido preto e chapéu, de forma objetiva direta, - (é vista em campo, de costas, o corpo inteiro e, depois, em 
meia-figura, a câmera por trás, avançando na sua direção) - diante de uma estrada de terra batida; mas, ao mesmo tempo, é uma câmera que se movimenta, não é invisível, e que denuncia a presença de uma subjetividade mediadora, uma consciência extra-campo que pode estar vindo de um outro tempo, por exemplo, o tempo futuro, onde estariam as três personagens no barco - (e, no caso, traduziria o ponto de vista da personagem que narra o episódio, - a Mulher 1, - ou as duas outras que ouvem, as personagens narratárias, no caso, o Homem 1, já que a Mulher 2, nesse momento, encontra-se, ainda, desmaiada) - ou, indo mais adiante, a Mulher 1, no ponto em que, através de seus dois olhos neutros, que não piscam, rememoram.

Se consideramos a origem, o ponto anterior à moldura, então, é o narrador extradiegético quem se denuncia ${ }^{20}$.

Neste quinto plano, a câmera avança na direção da mulher,- a Mulher 1, - que pára, por um momento, diante da estrada de terra batida, deserta, castigada pelo sol. A câmera gira em torno dela como se sentisse sua vertigem diante do calor: ela pára, por um momento, tira o chapéu, um lenço da bolsa que passa à altura da fronte.

Depois, retoma a caminhada. A câmera, mais uma vez, ao contrário de quando no procedimento clássico, quer manifestar sua independência diante do seu foco narrativo, no caso, a personagem da Mulher 1. Ela avança por trás, na sua direção, mas a tira de quadro, para apontar, como um olhar independente que se denuncia ( o olhar do narrador extradiegético que se apropria do momento para mostrar algo que lhe interessa mostrar, como se desejasse escrever algo através e com a realidade que vê $\hat{~}^{21}$ ), o infinito da estrada que se perde ao longe e, depois, em movimento à esquerda, denunciar a paisagem devassada, queimada, que se descortina para além de uma cerca, cerca que, ao ser percorrida pela câmera, irá levá-la a redescobrir, agora já caída junto à cerca, prostrada, a Mulher 1.

Neste momento, a câmera, traduzindo um ponto de vista de uma narradora intradiegética situada em um tempo ulterior ao que estamos vendo, ou o de um narrador extra-

\footnotetext{
${ }^{20}$ Para cada um dos casos, encontraremos, no filme, um plano, uma passagem, que justifique os respectivos pontos de vista. Para nos atermos ao mais explícito, tomemos a perspectiva do ponto de vista de uma das personagens, como veremos no final do bloco, no retorno ao ponto zero da narrativa (a estrutura de primeiro grau), quando temos o plano da Mulher 1, no barco, agora em contra-plongée (raro momento na estrutura de primeiro grau em que se sai do plongée para o contra-plongée - a câmera afirmando, na grandiosidade do quadro inicial que se insinua pela fusão, - câmera de baixo para cima, aumentando o volume do rosto da Mulher 1 - o ato de autoria da fala) seus lábios se movendo, como se terminando de contar o que, então, acabou de se passar, pelas imagens, ao Homem 1.

${ }^{21}$ A respeito da câmera que escreve a realidade, cabe mencionar os textos de Pasolini, "A língua escrita da realidade" e "O cinema de poesia", ambos em O Empirismo Herege.
} 
diegético contaminado pelo olhar de sua personagem, é uma câmera que se quer evidenciar na manifestação de uma intenção que é explicitada: ela une, em um mesmo plano, sem cortes, personagem e paisagem e, abandonando a personagem por um momento, faz chamar a atenção para o aspecto da paisagem que quer relacionar num mesmo estado de coisas, numa mesma atmosfera. No conjunto, neste segmento, temos planos que se organizam de forma a salientar um mundo corroído pelo tempo, situado em áreas limítrofes entre vilarejo semiabandonado e natureza, um espaço a caminho das ruínas, à margem, que guia e orienta a personagem na direção das linhas de fuga que se fecham no infinito.

O plano que conclui o segmento, indicador do afastamento, de uma possível partida na vida da Mulher 1, é de um ângulo que tenta, agora, novamente, cobrir o todo de cima, sintetizar o tema a partir de um plongée, a partir da perspectiva do alto de um poste, do detalhe de um de seus isoladores na trave de madeira superior: os fios elétricos acompanham as linhas de fuga do quadro, compondo com as linhas da estrada de terra batida que se perde ao longe, e na qual vê-se, lá abaixo, caminhando na direção do infinito, a Mulher 1. Este plano, ponto de culminação no segmento, reforça a idéia: o deixar-se ir, a terra a expulsar nossa personagem.

Linhas do poste, movimento da mulher na direção do vértice das linhas de fuga, reforçam forças centrípetas (idéia de fechamento) ao invés de centrífugas (movimento contrário, vindo do fundo, extravasando-se pelas bordas). A presença do poste, dos fios de eletricidade, neste final de segmento que configura a partida da Mulher 1, justapõe-se ao imaginário do local ermo, de casas velhas e ruelas de terra batida, vindas de um mundo de origem rural que ficou à margem de algum processo de desenvolvimento, o ícone deslocado de uma modernidade desajustada.

A eletricidade que paira sobre os rincões nos traz, na imagem, novamente por fusão, o movimento possante da roda de um trem (outro ícone do moderno) que, girando, por fusão, é associado ao giro da roda de uma máquina de costura que,surge, imponente, filmada em detalhe, em contra-plongée (a câmera de baixo para cima ${ }^{22}$ ). Diante dela, em um novo plano, vamos reencontrar a Mulher 1.

\footnotetext{
${ }^{22}$ A respeito do papel transformador da máquina de costura, de modelo industrial, como a do filme, que facilitou o acesso da atividade aos diversos segmentos do público feminino, juntamente com os moldes e manuais de corte e costura que a acompanhavam no processo de sua difusão junto às comunidades rurais nos Estados Unidos, no começo do Século XX, em particular, no que se refere à figura da costureira e o papel de cunho sociológico de que se revestia, no Século XIX e anteriores, como mediadora entre duas culturas, a aristocrática.
} 


\subsection{Repassando as diferenças com o bloco Mulher 1 - o tempo (cíclico) da repetição - rituais do cotidiano - das seqüências iterativas e pseudo- iterativas}

Na associação das formas das rodas metálicas girando no tempo, em montagem rítmica e associativa própria a procedimentos no cinema construtivista russo do período e à vanguarda francesa, realizamos, no plano mental, a compreensão da elipse de uma ação física (os fatos que levaram a Mulher ao novo espaço e tempo em que se encontra costurando), e da idéia de um processo que se faz subentender pela associação de imagens: a mulher, tendo partido do rincão anterior, encontra-se, agora, em um outro local, em um outro tempo, e agora, nesse espaço exíguo, que lhe é próprio porém precário, minúsculo e enclausurado como em uma prisão, ela costura.

Na passagem para um novo segmento dessa estrutura de segundo grau do filme, observamos uma mudança no tratamento da natureza do tempo e momentos mostrados.

No primeiro segmento, presenciamos momentos singulativos, únicos e decisivos, deflagradores de rupturas e mudanças (mulher se desvencilhando da mão do homem que tenta retê-la e partindo), uma atitude da personagem no plano da ação física, com curvaturas no desenho rítmico-dramático:

1. forte: ruptura - câmera na mão, veloz, indicando detalhes de movimentos, gesto do braço da mulher se escapando das mãos do homem que tentam segurá-la;

2. melancólica: duas caminhadas lentas da mulher que entra em quadro e se dirige ao fundo;

3. vertiginosa-ascendente e queda: mulher pára na estrada de terra, no sol a pino, câmera gira, queimada; mulher caída na cerca;

4. fechamento-conclusivo: mulher caminha ao fundo, abaixo do nível da altura do poste elétrico). 
Nesse segundo movimento, temos, agora, justaposta, uma seqüência que é puro transcorrer do tempo sobre coisas e corpo humano em momento de repouso, de inércia, de paralisia. Nela, não presenciamos atos singulativos, mas a presença dos tempos mortos.

Em plongée (câmera alta), o enquadramento da perspectiva novamente de um olhar superior, onisciente (o narrador extra-diegético ou o intra-diegético que, da perspectiva de um tempo ulterior, pode rememorar através de um sentimento de onisciência), recorta o quadro de modo a acentuar o espaço apertado, fechado, de um cubículo. Apesar de ser um plano de conjunto, o campo de visão é pequeno, não temos muitos detalhes do cenário: um objeto, em primeiro plano, indefinido, obstrui a visão no canto inferior esquerdo do quadro, dando a impressão de coisas entulhadas, de aperto. Vê-se a máquina de costura lá embaixo, de modelo industrial., diante da qual a Mulher 1 trabalha, usando os cabelos presos e escovados, um colar e um vestido escuro com pequenos detalhes, quase imperceptíveis, de bolinhas brancas, - vestido que pode ser o mesmo, já então todo rasgado, não tendo restado dele senão uma tira sobre o saiote branco, no final, nas seqüências do barco.

O local é pequeno, fechado, como uma cápsula de isolamento, como é, de certa forma, o barco na estrutura de primeiro grau. Na máquina de costura, a Mulher 1. Ela a opera absorvida. Depois, pára por um momento, ajeita os cabelos atrás. Seu olhar dirige-se para o alto como num suspiro, uma expressão de abatimento. Torna a abaixar o olhar, volta a levantá-lo, o rosto reclinado sobre a mão na mesma expressão de abatimento. Seu olhar para o alto depara-se com uma clarabóia que lhe cerceia o céu, quadriculando-o, aumentando a sensação de claustrofobia, de isolamento do mundo exterior. Ao lado, os objetos de costura ganham corpo, volume, evidência. Recompõem o pequeno universo que faz a idéia da experiência de mundo daquela mulher: ovo de cerzir, colchetes, retrós de linha, botão, a fita métrica. Os objetos desfiam aos olhos em planos de detalhe que lhes acentuam as formas geométricas, os círculos, os buracos, o serpenteado da fita métrica, as formas arredondadas para os dedos no cabo de uma tesoura. Sente-se o tempo que transcorre sobre esses objetos estáticos, parados e que pulsam no cotidiano monótono dessa mulher que, quando a vemos novamente, continua parada, o olhar perdido para o alto. Como se despertasse de um pensamento, de um devaneio, ou de um nada que observasse, ela se volta, após esse longo tempo em que, objetivamente, nada acontece, e retoma, resignadamente seu trabalho. Ao lado da máquina, vêem-se croquis de vestidos, desenhos seriados para serem copiados como moldes. A mulher costura, desta vez, com a mão, corta a linha com os dentes, apanha uma tesoura, seus dedos crispados acompanham a linha do corte da tesoura cujas lâminas, abertas, 
lembram (a fusão na imagem começa a fazer a passagem dos planos) as páginas semi-abertas e, ao mesmo tempo, semi-dobradas de uma folha dupla de papel (que se "ligarão" com a imagem das folhas abertas de um jornal).

Através do tempo dilatado em que esta seqüência é vista, a minúcia em recompor a experiência do tempo em uma atividade na qual a mulher está a se ocupar (costurar), temos uma atmosfera de seu cotidiano num determinado período de sua vida.

Nesta estrutura narrativa de segundo grau, a idéia de uma onipresença do não-tempo (o a-temporal) parece ceder a um sentido de limitação e parcialidade do tempo (portanto, um sentido de relatividade, de transitoriedade diante da vida). Estar naquele lugar, igualmente limitado como nas condições anteriormente vistas, é apenas um pedaço da vida daquela mulher e não o seu todo. Agora, não se trata do "para sempre”. Agora, trata-se de apenas um período da vida daquela pessoa, entre outros acontecidos. Um período determinado, entre limites. Provisório, transitório, efêmero. Condenados à finitude, já que “aconteceram” no passado.

Este momento em que a vemos, por outro lado, parece estar se referindo a muitos outros semelhantes a que suas atividades e instâncias estariam restringidas, naquele período, na freqüência do ritual de um cotidiano. Na classificação proposta por Gerard Genette nos estudos da narrativa ${ }^{23}$, poderia ser confundida com uma seqüência sumária ou freqüentativa, aquela que procura resumir, de forma condensada, um largo período de tempo diegético, através de exemplificação, com cenas ilustrativas, da qualidade dos eventos ali ocorridos. Pela maneira como é filmada, no entanto, com a presença do tempo interno próprio ao momento, faz dele único, singulativo. Momento único que, por outro lado, alude a uma série maior, a vários outros similares que aquela mulher teria ou estaria vivenciando naquele período, naquele vilarejo. Do ritual cotidiano, de várias outras seqüências possíveis de mesmo teor, seqüências iterativas, destacou-se uma - singular, única - como paradigma, como síntese daquele período e daquela vida: toda uma série de dias, meses e, quem sabe, anos, em que ela teria estado submetida àquela condição. O que emana aqui, novamente, é a evidência de uma condição, de uma atmosfera, mais do que a descrição de um enredo, de uma intriga de teor literário. Se, no primeiro segmento deste bloco, tivemos atos singulativos que poderiam se ter passado em curto período de tempo mas capturados na intensidade de sua duração temporal e sensorial (instante dilatado ao máximo: por exemplo, a caminhada da mulher sob o brilho intenso da luz do sol), agora temos igualmente uma seqüência onde seu tempo diegético é

\footnotetext{
${ }^{23}$ Seqüências iterativas e pseudo-iterativas. Ver Gerard Genette. Idem.
} 
curto (talvez, uma tarde, ou até um instante de “devaneio”, em que a mulher, sonhadora, ainda que abatida, deixa-se levar por seus pensamentos num momento em que costura), a temporalidade é escandida, mas que quer dar conta de um período de tempo diegético maior, um grande período de tempo onde estariam ocorrendo momentos semelhantes à este que emerge como síntese dos demais. O singular no interativo, de acordo com Gerard Genette ${ }^{24}$.

A justaposição entre os dois segmentos através da fusão entre os planos das duas rodas metálicas (do trem e da máquina de costura) que, por um efeito metonímico, dá a subentender a elipse de uma ação (uma viagem de trem que a teria levado àquele novo ermo onde passa os dias a costurar para fora), reafirma uma condição de existência: o ato de ruptura não resultou em mudanças substanciais; a fuga ou partida, no final das contas, acabaram por levá-la a ser prisioneira de uma nova condição de vida, pequena, provisória, sem perspectivas de sonho. $\mathrm{O}$ ato singulativo, de ruptura, não foi capaz de conduzir senão a um estágio cíclico, de repetições e iterações, tal como os rituais do protótipo de um cotidiano moderno.

\subsection{O plano que deflagra - condensação, projeção e síntese da montagem - relatividade do plano}

Antes que se parta para a conclusão, temos o plano que anuncia novo gesto singulativo, de atitude, e que deflagra novo movimento da personagem: a câmera percorre as pernas da Mulher 1, em panorâmica ascendente, até as folhas abertas de um jornal que ela folheia, voltadas para nós, espectadores. Num movimento de avanço, chama a atenção para o detalhe da notícia impressa: "fuga da mulher da prisão através da cumplicidade de um carcereiro”. Ato contínuo, faz a panorâmica de regresso, na vertical para baixo, desta vez, descrevendo no detalhe, o que já mostrara no início do movimento: o fio da meia que se desfaz.

Chamar a atenção, de modo explícito, para um irrisório mas marcante detalhe de desgaste material, como se fixado em uma memória, indicativo das precárias circunstâncias de vida da personagem, é tão importante quanto lançar o novo dado através da palavra escrita e que nos chega na forma de uma notícia impressa, fornecendo pistas para leitura, no nível do anedótico, de motivos policiais. Insinua-se, neste desvio de atenção, a tendência à dissolução

\footnotetext{
${ }^{24}$ Ver o estudo de Geraldo onde menciona essas passagens de transposição do tempo feitas sobre planos de articulação das personagens envolvidas: pescoço e lábios da Mulher 1 terminando de falar - movendo os lábios e do Homem 1, pescoço e orelha, inclinado sobre si mesmo, sentado).
} 
de temas redutíveis à exposição cronológica de um enredo literário em detalhes imagéticos que, destacados do natural, são hiperbolizados, acentuando, gradualmente, a obsessão pelo tema: a corrosão do tempo sobre as coisas e pessoas, a efemeridade de cada coisa e, no lamento com que se olha, o desejo de se perpetuar o eterno nessa efemeridade.

Ao mesmo tempo, a notícia impressa no jornal e o detalhe do rasgo da meia pelo uso (o texto escrito, no jornal e o rasgado da meia, na imagem) - operam a síntese da condição de vida da personagem: algo da ordem do precário, do provisório, do limitado: o puído pelo tempo.

A notícia que se lê no jornal, inadvertidamente, vista pela câmera, (não se sabe se pela própria mulher que o folheia), nos dispara possibilidades de sentidos que nos leva a rever todo o conjunto de segmentos vistos neste bloco, imantando-os de um novo significado provocado pela associação com esta nova informação que nos é dada. Num segundo, percorremos os dois segmentos e tendemos a rever a mulher como a própria fugitiva, o homem que a tentou deter como a projeção da figura do carcereiro que, diz a notícia, poderia ter sido seu cúmplice na fuga, os planos de sua "partida”, como representativos de sua "fuga”.

Depois, no segundo movimento deste mesmo bloco, tendemos a vê-la como em novo refúgio possível, fugitiva escondida em algum outro vilarejo perdido, em um ermo qualquer do interior do país, vivendo do expediente de costurar para fora, em momento de reclusão provisória, e onde a notícia no jornal deflagrará nova necessidade de partir, de fugir. A Mulher 1 está em fuga constante. E, no entanto, como já visto, nada nos indica que as grades da janela por trás das quais víramos a Mulher 1 no início desta sua narrativa fossem, de fato, as de uma prisão. E nem que os planos seguintes, dela caminhando rente às fachadas de casas envelhecidas, ou ao muro carcomido pelo tempo, ou ainda na estrada de terra batida, a indicassem como fugitiva de uma cadeia. Os planos da mulher se afastando ao longe são lentos, ela caminha lentamente, e ademais suas roupas estão compostas, usa um conjunto de saia e casaco, chapéu de passeio, uma bolsa, não se trata, absolutamente, de alguém em rota de fuga de uma prisão, mas sim de alguém que simplesmente deixa algum lugar. Ou ainda: alguém que, simplesmente, tendo saído de sua casa, tendo certamente se desvencilhado de um homem, caminha. Exaspera-se, sente o calor da paisagem, mas, basicamente, caminha. Sua “partida”, na imagem em si, nos planos em que acontecem, referem-se mais a uma situação genérica desse deixar no plano afetivo, existencial, de quem foge mais de uma condição de vida, de existência que lhe é precária e aprisionante (e que renega), do que de uma contingência física específica como a de ser fugitiva de uma prisão. Se tais planos mencionam 
uma partida e se existe, de fato, uma fuga da Mulher 1 da prisão, a partida vista na tela, nos planos da fato, estão se referindo a um outro tempo qualquer, não aquele imediatamente posterior à fuga. O que, no caso, deixa subentender, mais uma vez, a elipse de um tempo, transcorrido entre a fuga propriamente dita, e os planos em que a vemos caminhar na direção da linha de fuga dos quadros. No bloco narrativo desta Mulher 1 como um todo, temos a justaposição de segmentos autônomos (o da partida, o da costura e - ainda não vimos em detalhe - o da evocação do vilarejo que vem a fechá-lo em sua estrutura concisa). Eles se justapõem e as conexões se deflagram a partir das associações provocadas. A informação dada pelo jornal nos desperta associações com o que vemos na tela e que talvez não se encontrem, de fato, contidas em cada um dos planos em si. Condensamos, em nossa mente, os eventos vistos em uma outra ordem, provocada, instantaneamente, e criamos uma nova imagem, outra, a partir da síntese processada através dos mesmos eventos vistos. Nada indica, nas imagens em si, que se trata de uma fuga da prisão. As linhas de fuga dos enquadramentos, em perspectiva, que acentuam a força do movimento em direção ao fundo são quem, talvez, nos evoquem alguma idéia de "partida". Mas o chapeuzinho de passeio, a pequena bolsa, os trajes todos compostos não refletem, necessariamente, uma fuga de uma cadeia. Da mesma forma, a notícia do jornal: a câmera nos destaca a notícia, mas associá -la à própria mulher, nossa personagem, é uma das possibilidades de leitura (apreensão e interpretação) que a imagem criada pela montagem pode nos oferecer. Na tela, nada nos afirma que aquela mulher possa ser a evadida da prisão. A notícia, no jornal, está situada na página que se encontra voltada para nossa direção (do espectador, da câmera) e não para o lado da personagem que o lê. Depois, ela vira o jornal de posição e podemos intuir que, possivelmente, ela própria a leia. Mas, como visto, a câmera desvia seu percurso e volta a nos mostrar o fio de sua meia que se desfaz, mais interessada no detalhe que assinala para o desgaste, a dissolução que o tempo nos impõe do que para a continuidade da possível história que possa estar a se formular em nossa mente.

Aquela Mulher 1 poderia ser outra... não necessariamente a fugitiva em questão.

Uma costureira. E daí, o espaço fechado, onde a vemos costurar, - (o cubículo, e cuja fachada não vemos, apenas seu interior, que também não é visto no conjunto, mas inferido, pelos detalhes de cantos dos enquadramentos, a clarabóia, os objetos de costura...) - onde supostamente ela viveria em outro lugar, fosse ela a fugitiva, pudesse ser o mesmo, da mesma cidadezinha de ermo com suas casas envelhecidas, de calçadas comida pelo mato, das estradas de terra batida, e da parede, da porta da casa do início do filme, da qual ela saíra para o 
passeio, fazer parte do mesmo lugar, ser a vista externa deste cubículo onde ela, agora, costura. Das associações é que se cria a nova imagem que é, portanto, de natureza mental, pois se dá em nossas mentes e não na tela em si. Assim, em Limite, nesta primeira das estruturas narrativas de primeiro grau, a montagem e os enquadramentos são feitos de tal forma que se permite pelo menos dois níveis de leitura possível: por um lado, assume-se a forma de um motivo dramático: mulher foragida da prisão; por outro, apenas a captação de momentos de uma personagem comum: a mulher que vive de costura, que sai para caminhar, o vilarejo onde vivia, a idéia de um cotidiano que surge por trás. Por este prisma, toda a lógica de montagem que rege em especial este primeiro dos blocos das estruturas de segundo grau remete, em essência, ao método desenhado por Eisenstein, mesmo que, na dilatação do tempo e na arbitrariedade de certas angulações e movimentos de câmera, nos traga à memória outros estilos, mais a haver como a estética de Bazin e Kracauer, cineastas da continuidade de tempo e da imanência do real como, por exemplo, Murnau.

\subsection{A evocação do lugar - o espaço como condição de vida}

O bloco concluirá com planos que surgem, à primeira vista, aleatoriamente, em montagem aparentemente desconexa, à guisa de moldura de fechamento desta primeira narrativa de segundo grau, e que nos mostram imagens de um vilarejo qualquer, esquecido no ermo.

São planos que priorizam a atmosfera de isolamento, de abandono, de vazio de pessoas: vemos, em ângulo obliquo, o telhado de uma casa de parede envelhecida recortado contra o céu. Na ponta, contra o céu, destaca-se a figura de um urubu. Depois, a câmera avança sobre o caixilho de uma janela fechada (sem vida por dentro). Na rua deserta, o mesmo ângulo inclinado, folhas de papel voam, varridas pelo vento, vê-se o muro velho, descascado, uma casa de paredes corroídas pelo tempo onde surge uma velha para fechar a janela, uma porta de madeira sendo batida pelo vento, abandonada, ao léu. Estes planos ressentem-se da ausência de pessoas (a não ser pela figura não identificável que surge para fechar a janela) e são, em nossa mente, evocativos de uma memória. O vento faz a porta de madeira bater à esmo, várias vezes. As pessoas se foram, todos se foram. Partiram. O plano do girar da roda do trem faz voltar novamente no tempo, ao presente contínuo da situação do 
barco, onde só agora podemos ver a Mulher 1, seus lábios de movendo, como se terminasse de contar tudo aquilo.

E ela ressurge, no início desse retorno à estrutura de primeiro grau, o tempo zero da narrativa, em contra-plongée (vista de baixo para cima), o quadro lhe cortando a parte superior do rosto (os olhos), detalhando a altura de seu pescoço (sua garganta), seus lábios que se movem. Ela fala (imensa) e nós estamos "sub-julgados” à sua voz (imagem). A montagem por justaposição nos obriga, a cada momento, processarmos uma outra montagem interior, nossa, feita ulteriormente, de modo a que projetemos sobre o visto as novas informações recebidas (pela imagem, já que a palavra aqui inexiste. Como dito, no filme todo, apenas uma fala.), re-elaborando novos sentidos sobre fatos que, sendo eles mesmos, cada qual em seu tempo e momento, em tese, seriam anódinos face ao imaginativo.

Pela montagem ulterior que processamos mentalmente, podemos assim deduzir que os planos que encerram este bloco, todos filmados sob ângulos que desequilibram o nível do enquadramento, na verdade, referem-se àquele pequeno mundo de província, sugerindo o cotidiano monótono de vidas miúdas, esquecidas, sem perspectiva, vidas deixadas à margem, onde a Mulher 1 acabara por sempre cair e do qual desejava fugir. $\mathrm{O}$ mundo evocado de acordo com as imagens que vêm na mente de quem a ouve (no caso, o Homem 1 ou nós, espectadores, identificados com ambos, ou do narrador extra-diegético, o autor). Imagens evocativas, tais como vêm à lembrança ou à mente enquanto sugestão: daí a leveza (e a melancolia) sugeridas pelos enquadramentos todos eles em ângulos oblíquos, inclinados, fora de prumo, ou com a câmera avançando fixamente sobre um detalhe (no caso, o caixilho da janela). Imagens evanescentes que parecem flutuar na memória.

\subsection{A marca do humano}

A presença dessa subjetividade - a marca do humano - é, enfim, o que define os sentidos de todas estas estruturas narrativas de segundo grau. Agora, podemos ver mais claramente que procedimentos da câmera arbitrária, de modo a, por exemplo, não ter revelado o rosto do homem que tentou detê-la, - a Mulher 1 - no fundo, são indícios da presença dessa subjetividade que traz à tona reminiscências que respondem, no fundo, a mecanismos de atenção e interesse de acordo com projeções afetivas da personagem que as reconta (narrador, no caso, intra-diegético) ou de quem ouve os relatos (narratário intra-diegético, para o caso de 
considerarmos tudo da perspectiva do Homem 1 que é quem, na diegese, poderia estar ouvindo o relato da Mulher 1).

Não se vê o rosto do homem que tentara detê-la porque, no fundo, para a Mulher 1, este homem pouco lhe significou, ficando marcado, em sua memória, mais o desejo da partida, de deixar uma determinada condição, que lhe fosse opressora e limitada. Do ponto de vista do narratário, ou de nós, espectadores, identificados com esse narratário, igualmente, por não o termos, de fato, conhecido - este homem "desconhecido”, de identidade obtusa (foi carcereiro? Foi seu amante?) - igualmente, só podemos ter em nossa memória sua figura, mas não seu rosto. O que sobressai disso tudo, através desses três segmentos vistos na primeira das estruturas narrativas de segundo grau (1. caminhadas de partida da Mulher 1; 2. Situação em que se a vê costurando em um espaço reduzido, confinado; 3. Evocação de imagens de um vilarejo perdido no ermo) são, por via indireta, manifestações de um determinado sentimento frente ao mundo que é de recusa, desejo de ruptura com circunstâncias limitadas de uma vida, acompanhado da desolação, da melancolia, da insatisfação silenciosa, do desespero profundo, individual, solitário. O outro sentido que se revela é, como já visto, o de um pragmatismo curtido no circunstancial e nas perspectivas do imediatismo da luta inóspita pela sobrevivência, na medida em que não se vê, da parte da Mulher 1, nenhum sinal de apego, nenhuma demonstração de afeto para com o mundo ao qual está vinculada e que rejeita. Um profundo sentimento de insatisfação, de inquietude sufocada (o espaço claustrofóbico em que passa os dias a costurar). Ficaram-lhe apenas, na memória, aquilo que the foi mais determinante, mais decisivo: os gestos de ruptura (do homem do qual escapou, nada lhe resta, nem mesmo seu rosto), os caminhos ermos de desolação, a luz do sol implacável, o vilarejo perdido em meio à ventania.... Impressões sensoriais e aquela situação que remete aos dias monótonos, vazios e sem sentido diante de uma máquina de costura, como aquela tarde ou manhã que lhe ficaram (e nos ficam) para sempre marcadas em nossa memória.

Assim, por via indireta, através da descrição de espaços, momentos e vazios, temos, difuso mas consistente no plano do sensível, evidenciando-se, emergindo, aos poucos, um temperamento, um modo de sentir e de se relacionar com as coisas, uma identidade que é o da personagem que se faz, neste bloco específico, como foco narrativo: no caso, a Mulher 1. 


\section{O BLOCO 2: A HISTÓRIA DA MULHER 2}

\subsection{Da estrutura}

Numa inversão de procedimentos, se no Bloco da Mulher 1, concluíamos com a evocação do pequeno mundo do qual ela ansiara por partir, aqui, iniciamos com a evocação do lugar onde a personagem viveu em um período de sua vida: uma indeterminada aldeia de pescadores, apresentada no tratamento formal similar ao empregado nas seqüências de abertura e de final no Bloco 1 (a câmera em enquadramentos arbitrários, sem normas clássicas de composição, priorizando detalhes fragmentados numa montagem sem a preocupação em tecer uma descrição cronológica e ordenada do espaço, e sim traçar uma impressão subjetiva sobre o que se vê e se organiza na tela).

Num segundo segmento, localiza-se a personagem (a Mulher 2) nesse espaço, em um determinado dia em que, regressando para casa com a compra de víveres, depara-se com o marido bêbado, caído. Não suporta a imagem, retira-se e caminha para o topo de um penhasco onde se põe, a sós, nos seus ruminares. Para efeito de análise e, no filme, este segmento pode ser dividido em duas partes distintivas: momento em que ela se dirige para casa, vê o marido e caminha na direção do penhasco; e momento dessa Mulher no penhasco.

O terceiro segmento estabelece com o anterior (a mulher no penhasco) uma continuidade de tempo e sugere com ele, apesar de não se completar em sua fatura, uma montagem paralela que pode designar a idéia do simultaneísmo de tempo: "enquanto a Mulher 2 está no penhasco”, vemos seu marido dirigir-se ao local de trabalho, o cinema onde é pianista nas músicas de acompanhamento para os filmes.

Há ainda o epílogo, um plano de fechamento (conclusivo) deste bloco que, realista, pela individualização que lhe é dada, assume conotações mais amplas: o plano onde se vê a fachada da residência do casal: primeiro, a porta, depois, as janelas, fechadas. Designam a idéia de um vazio em seu interior, um fim: a casa que foi fechada, a vida em comum que desapareceu, o abandono. Subentende também uma elipse de tempo, onde localizar-se-ia a partida, o desfecho da vida em comum para aquele casal. Procedamos à análise: 
É, novamente, o recurso de uma fusão, lenta, que deixa, por alguns instantes, sobrepostos, dois planos, de tempos diferentes, que se associam, que somos levados à segunda das estruturas narrativas de segundo grau, o foco narrativo, agora, na Mulher 2.

\section{1.a. Evocação do lugar - a praia dos pescadores - equivalências entre as estruturas}

O plano que privilegia o detalhe do pescoço e, por conseguinte, a orelha (o ouvido) do Homem que, no barco, sentado, reclinado na postura de visível abatimento, está na posição passiva de quem ouve, gradualmente, cede ao de uma outra imagem que se vê surgir, vinda de um outro espaço, um outro tempo: a guelra de um peixe que pulsa, agoniza, em detalhe, como se lançado em uma área mais seca, na areia, já fora das águas do $\operatorname{mar}^{25}$.

O detalhe do peixe que agoniza se sobressai, sobretudo se pensamos, através da montagem ulterior processada em nossa mente, que aquele cadáver de peixe, ou um da sua espécie, é o que será conduzido na cesta da Mulher 2 para lhe servir de alimento. Este peixe que agoniza, assim como os abutres do início do filme, e os parasitos a devorar troncos depenados na terceira das estruturas de segundo grau (Bloco 3, do Homem 1) ajudam a compor um dos temas visuais que sintetizam, em última instância, o principal - o limite: a condição básica predatória da vida que se alimenta de corpos putrefatos, em processo de decomposição.

É com o detalhe do peixe que agoniza na areia, que temos, - (no tratamento de estilo semelhante ao de como iniciávamos o Bloco 1), - a mencionada série de planos que privilegiam detalhes, recortes, fragmentos do qual, no início, não se tem o todo e onde o uso da câmera deixa clara a presença de uma subjetividade que a orienta de modo bastante arbitrário, sem obedecer os princípios da decupagem descritiva e transparente no cinema clássico.

A ocupação, aqui, é a de nos dar conta de um determinado processo: o lugar, uma praia indeterminada de pescadores, é evocado, como no primeiro bloco, no plano de uma memória que se reconstitui. Sua recomposição por imagens se faz a partir de detalhes tais como venham à uma mente que receba diretamente a impressão do visto ou sentido através das imagens em um outro tempo ou no imaginativo, ao invés das linhas em equilíbrio próprio

\footnotetext{
${ }^{25}$ Gerard Genette - Instância narrativa.
} 
a uma geometria euclidiana (o “eu” centralizador, organizador do espaço) que pretenda reproduzir, numa cópia fiel, o original.

Os planos surgem ligados de um modo aparentemente desconexo: o fundo de um barco, desta vez seco, que, dependurado no ar, oscila (deslocamento visual que, no contexto do filme, neste momento, através dos elementos de que se compõe, provoca o sentido do inusitado - "barco oscilando no ar” - ao contrário do "barco naufragado no mar”):

1. A câmera, na mão, avança sobre a proa do barco, mas esse movimento não é de todo brusco e, de certa forma, deixa-se submeter ao movimento de oscilação do barco que é o que prevalece: uma oscilação que nos deixa a impressão de flutuação... “no ar” (ao contrário, por exemplo, do modo brusco, sinalizador de ruptura, com que a câmera dera a "partida”, a “arrancada”, do movimento do rosto da Mulher 1 por trás das grades para a porta a ser aberta pela mão do homem, no início do bloco referente à história da Mulher 1);

2. detalhes de um menino que avança para a câmera, descalço na areia, enquadrado da cintura para baixo, onde não se vê seu rosto, e que carrega um peixe em uma das mãos e papel para embrulho na outra;

3. das pernas de um homem sentado sobre as quais vemos suas mãos que contam dinheiro (igualmente, não vemos seu rosto);

4. de parte do corpo de um homem retirando água de um barco;

5. de um cesto de peixes de onde se vê um ser retirado e sombras de homens sobre ele;

6. ... e, novamente, o barco flutuando no ar: detalhes que nos dão conta de um pequeno comércio de peixes à beira-mar.

A montagem não nos avisa, não descreve uma ação ou um local determinado, mas nos lança fragmentos, obrigando-nos a reprocessar as ligações, automaticamente, perfazendo-as, reconstituindo, em nossa mente, interiormente, num só golpe, numa só imagem (o conceito de imagem, portanto, utilizado aqui, novamente, no sentido "Eisensteiniano" da expressão: a imagem como síntese resultante de um processo de montagem entre duas ou mais célulasnúcleos autônomas), uma determinada geografia (no caso, uma indeterminada praia) e, simultaneamente, seu processo sócio-econômico (o modo de se viver naquela geografia, o comércio de peixes).

Ao mesmo tempo, podemos observar que há uma lógica estrutural e um certo respeito à noção da contigüidade espacial na ordem de exposição dos detalhes que orientam para a 
apresentação deste espaço: o mencionado segmento limita-se à configuração do espaço, preliminarmente, apenas da orla marítima para, somente a seguir, ainda no mesmo tratamento de decupagem de imagens, partir para a abordagem da parte urbana do espaço propriamente dito, no caso, um vilarejo à beira-mar.

O plano que fecha o segmento da orla marítima, do espaço dos pescadores, é bastante singular na síntese de efeitos plásticos e de sentidos que mobiliza: é o primeiro plano, nesta seqüência, que mais se aproxima ao que seria a vista geral da praia: ela nos é dada através dos fragmentos, agora dentro do campo de visão (no interior do plano) visto através do efeito do contra-luz obtido pela imagem da hélice do barco a motor em posição de repouso, desligado, em primeiro plano. Recorta-se, em segundo plano, um determinado pedaço da praia, onde se identificam, ao longe, alguns barcos de construção mais primitiva, de madeira, com as silhuetas de pescadores. Tal detalhe é, na perspectiva do quadro, quase apenas um indício na faixa superior, para onde converge a linha de fuga em curva, desenhada pela orla do mar, à esquerda do quadro, com a sombra de parte do barco a motor a cobrir o centro, como uma mancha escura que interfere no campo de visão. O contra-luz da imagem do moderno (o barco a motor), em primeiro plano, em repouso, inoperante, oculta-nos parte do que poderia ser uma paisagem pitoresca do conjunto da praia, um típico regional quase parnasiano, antigo (os barcos “primitivos” dos pescadores) mas que é “quebrado", fragmentado, permanecendo porém como pano de fundo, como camada anterior que lhe antecede, historicamente, no tempo.

\section{1.b. Evocação do lugar - o vilarejo - marcas da subjetividade na imagem e freqüência rítmica}

O plano de uma fonte de água pública - um chafariz - para onde a câmera avança, desta vez, em movimento mais incisivo, para a bica de onde jorra a água, marca o início da apresentação dos detalhes urbanos do vilarejo. São movimentos de avanço que se distribuem ao longo da seqüência, em grupos numericamente ímpares, e em escala progressiva - (um, três, cinco avanços) - e que se intercalam, pontuando, entre os demais planos que mostram pontos da localidade.

A estrutura é curiosa pois, se chama atenção pelo inusual da forma, nos faz lembrar da figura do chafariz como marco no aparecimento das primeiras concentrações urbanas no país: 
as bicas de água natural, onde paravam os viajantes, ao redor da qual se constituíam os entrepostos e as aglomerações de casas. No filme, nesta seqüência, utilizar os avanços da câmera, enfatizando a bica de onde a água jorra como o eixo que estrutura, ritmicamente, esta apresentação do vilarejo, faz uma curiosa analogia com a forma histórica de um determinado processo que ocorreu na origem desses lugares. Uma outra figura análoga, como marco de fundação de uma cidade, o cruzeiro, surgirá em destaque num ponto de passagem para o terceiro ato (no caso, de conclusão) na terceira das estruturas narrativas de segundo grau no filme, correspondente à história do Homem 1.

O tratamento de câmera nos demais planos do vilarejo à beira-mar que orbitam ao redor do núcleo de avanços de câmera sobre o orifício do chafariz, é de estilo documental, e prossegue com a livre arbitrariedade na composição: o primeiro plano a nos mostrar uma fachada de casas, no caso, um casario, - ( um aglomerado de casas de portas estreitas e janelas de venezianas de madeira, de paredes com manhas de umidade e que dão direto à calçada ) - é filmado com a câmera tombada, caída de lado, ficando o casario na horizontal no quadro.

A câmera quer se soltar diante da realidade a se mostrar, como se solta, em panorâmica livre, - (o quadro fora de nível), - de uma mulher, de costas, lavando roupas na bica d’água pública, - (corrigindo à esquerda) -, para a rua de terra batida onde gansos ciscam. Depois, galinhas ciscam, entre poças d’água.

Uma pequena ponte de madeira sobre o córrego, singelo, trivial em si, observado, revela uma decomposição precisa, analítica, de um algo a mais a se revelar: neste plano, vêem-se dois níveis de naturezas diferentes justapostas, verticalmente, em um mesmo quadro: da metade para cima, o cercado retilíneo das ripas de madeira que compõem a lateral da ponte em composição ordenada, serial, numérica, de linhas retas e definidas; sob ela, o pequeno córrego que se confunde com a pequena margem de terra assaltada por pedras irregulares, uma pequena escada ao lado esquerdo, em distribuição um tanto confusa de massas, linhas e cores, com manchas do cheiro da umidade e do putrefato do orgânico aparecendo sob a sujeira do natural; em cima, uma natureza ordenada (da ponte, cultural, feita pelo homem); em baixo, a natureza desordenada, caótica, desajeitada, escondida na confusão de formas como um detrito, ao lado de outras marcas do humano como o pequeno degrau, o pedaço de uma casa com a porta semi-aberta, a janela, o reboco aparecendo.

Em tudo, no conjunto, a marca das coisas se envelhecendo, do antigo, do velho, do úmido, do sujo. E, novamente, um plano similar, em sua construção, ao já visto na seqüência 
da orla da praia (um objeto em primeiro plano que recorta pedaços de uma vista de conjunto ao fundo, como um ruído a se interpor entre nós e o campo de visão: novamente, um casario, talvez o mesmo já visto no início, em outro detalhe ao longe, casas lado a lado, de estilo colonial, fechadas e que, igualmente, tal como na paisagem da praia, surge redesenhada através do que permite ver o detalhe imenso, em contra-luz, de uma roda, desta vez não de um barco a motor, mas de uma carroça, talvez um carro de boi, parado, como se desativado, abandonado, colocado em primeiro plano de modo a interferir na visão de conjunto da fachada do casario, típica construção colonial.

Concluindo o segmento de reconstituição do espaço do lugarejo à beira-mar, - através dessas imagens que se assemelham a imagens refletidas de um lugar depositadas na mente de alguém, tal como as imagens da realidade refletidas de forma invertida e impressas no celulóide, pela luz, através da janela e do obturador de uma câmera, - temos, enfim, câmera a esmo que sobrevoa, em detalhe, os telhados do vilarejo, e depois, finalmente, de modo difuso, impreciso, uma vista geral, com as casinhas de portas estreitas, dispostas lado a lado, sempre fechadas, de forma serial, ruas estreitas, uma cidade pequena, e onde a câmera balança três vezes em movimento de ir-r-vir, de um lado a outro, como se quisesse rabiscar, fazer uma rubrica dissolvendo a visão, para regressar, novamente, ao detalhe dos telhados e só assim, com os telhados, concluir o segmento. Somente após essas imagens trazidas de modo impreciso e fluido, sensação de fluidez propiciada pelos movimentos oscilantes de câmera ou nos recortes fragmentados do real através de uma montagem por acúmulos de planos que se saturam, sem a preocupação de estabelecer conexão linear, explicativa, entre eles, é que podemos ter, finalmente, inserida neste local, um plano, desta vez, com a câmera em ponto de estabilidade, em quadro fixo e geral, a narração na terceira pessoa, objetiva e direta, nossa personagem, a Mulher 2. É, nesse momento, como se toda a flutuação de imagens “soltas” na tela se fixassem, se estabilizassem, para que se desse início a uma nova forma de cinema pois, a partir de agora, nesta segunda das estruturas narrativas de segundo grau, passa-se a acompanhar o trajeto da personagem em seu tempo contínuo, linear, quase no sentido literal, os cortes procurando respeitar as leis internas da continuidade, em negação quase radical ao cinema de montagem até aqui praticado.

O que estabelece a unidade neste primeiro segmento de "evocação do lugar”, como vimos, é a lógica expositiva de um sentido de ordenação estruturado mais numa determinada freqüência rítmica e visual do que num sentido semântico literário; são planos que se repetem para pontuar uma seqüência no estabelecimento de sua unidade rítmica: o movimento 
oscilante do barco pendurado no ar, que pontua a seqüência dos planos referentes ao segmento da orla marítima (aparece, repetindo-se, duas vezes); movimento de avanços da câmera sobre a bica d'água que pontua o segmento do vilarejo (três vezes, a cada vez, multiplicando-se em escala ímpar progressiva nos avanços da câmera sobre a bica: uma, três, cinco vezes); recortes de uma vista conjunta obstruída por um elemento em primeiro plano (no segmento da orla marítima, geral da praia pitoresca de pescadores - antigo - através do barco a motor desativado - moderno; no da aldeia, fachada típica de casario de modelo de construção oriundo do mundo colonial rural, de alvenaria, recortada pelo detalhes de uma roda de carro de boi, igualmente desativado - economia antiga). O que não abandona, de vez, a lógica de exposição de um determinado lugar através da natural contigüidade espacial: movimentação e comércio de peixes na orla marítima seguida dos planos da cidade que lhe é próxima.

\section{1.c. Da instância narrativa}

Se consideramos as circunstâncias da instância narrativa (a averiguação das circunstâncias em que ocorre a narração que estamos a presenciar ${ }^{26}$ ), podemos observar as ligações projetivas que se estabelecem entre a situação do barco a partir da qual as personagens se contam, ouvem ou rememoram suas vidas (o tempo zero da narrativa) e as imagens específicas do passado evocadas mentalmente (imagens de um cinema mental) diretamente mobilizadas e sugestionadas pelas circunstâncias da atualidade dessas personagens. As lembranças do passado estão contaminadas pelas circunstâncias do presente a partir do qual elas rememoram e tentam se recompor, ainda que de forma rarefeita, incompleta, fragmentada e esgarçada, enquanto identidades. Lembremos que esta seqüência a que nos referimos, a evocação do lugarejo à beira-mar, é a que abre o flashback, o bloco narrativo correspondente à Mulher 2, logo após o momento, na estrutura de primeiro grau, em que o foco narrativo, aos poucos, deslocara-se na sua direção e em que, pela primeira vez, se revelava o balde de sua provisão de água, no barco, completamente seco. O que leva à sugestão de uma supressão da carência atual e desesperada pela imagem da água que escorre, agora virtual, pois no plano da imagem, evocada do passado, onde a obsessão da atenção é mobilizada para o orifício, a origem, de onde ela jorra (os sucessivos, insistentes, obsedantes, avanços da câmera sobre a bica d'água), bem como os demais locais onde ela se faz presente:

\footnotetext{
${ }^{26}$ Na seqüência específica, um narrador que pode “cobrir” tanto interior, como o exterior de uma casa, ubiqüidade que, em muitos momentos do filme, é recusada.
} 
poças d'água onde as galinhas ciscam, o chafariz onde a lavadeira lava suas roupas, o córrego sob a pequena ponte. Relembramos que os planos finais do Bloco 1 (a história da Mulher 1) remissivos à localidade de onde a personagem fugira, traziam igualmente a presença do vento: vento sobre as folhas de papel na ruela, nas folhas da porta de madeira envelhecida que se deixavam bater abandonadas, prolongando, na memória, no passado, o mesmo vento que, pouco a pouco, os assola no presente, nas circunstâncias do barco . As rememorações reiteram os motivos do presente reafirmando um sentido teleológico onde tudo caminha para o desenlace: o temporal que virá no final do filme.

\section{1.d. A passagem do tempo - o antigo e moderno - uma contradição que se insinua na forma do olhar}

Nos dois planos gerais onde vemos uma paisagem "pitoresca” obstruída, no primeiro plano, por objetos em posição de inércia, abandonados - (na orla marítima, a hélice do barco a motor, em repouso; no vilarejo, a roda de uma carroça) - temos indícios de algo se processando no tempo. O motor desativado revela a inoperância do moderno diante de um bucolismo que se impõe pela inércia, imutável, entregue a sua própria natureza; a roda da carroça tombada faz compreender um tempo e um ciclo quanto aos meios econômicos e de transporte que, aos poucos, se esgota. Na identificação com esse universo em que os índices de realidade apontam para uma modernidade face a outra que lhe é anterior (no caso, o barco a motor face ao barco primitivo), em que, mesmo naquilo que é estático, sente-se a vibração de algo que está se degradando (o casario humilde da cidade, de cimento e alvenaria, como fundo aos “tempos da carroça”, para brincarmos com a expressão, ou mesmo à realidade dos pescadores, habitantes da orla, que, mais tarde, veremos explicitada, no filme, na forma de uma cabana a pau a pique, o barro na construção) -nota-se um desejo de desequilíbrio premeditado nos próprios enquadramentos, assim como nos repentinos movimentos e desvios da câmera, às vezes, sem aviso prévio, que se manifesta como um sentido de negação diante das formas tradicionais de composição (e montagem) tais como utilizadas no cinema clássico.

Ou seja, e mais tarde voltaremos ao tema, as formas transgressivas, no filme, nascem diante de uma desconfiança face aos índices de transformações que implicam sempre na idéia de uma ruína que se insinua, avança, comendo o vivo de algo que, inevitavelmente, é perdido, a favor de uma identificação, natural, com o desejo de perpetuação desse algo que é perdido, o 
antigo. Antes que o novo surja, ele já nasce puído, velho, deslocado, decantado em tom de lamento que se revela, e se sabe, inútil. (a lancha a motor em estado de inércia, os postes de eletricidade "perdidos” nas ruelas de terra batida, convivendo no esquecimento do mato e dos rincões, a bomba de gasolina entre botas e pés descalços, o trem que só conduz a ermos fechados em ciclos de uma rotina sem saída, o próprio cinema, como veremos à frente, na alegria ingênua dos “humildes”).

\subsection{Início do desenvolvimento da narrativa - um outro cinema - relações de simetria na estrutura}

Com o plano geral onde se vê, finalmente, à distância, em segundo plano, a Mulher 2 entre os pescadores no pequeno comércio de peixes, podemos proceder ao início do segundo grande segmento (segundo ato) deste bloco. O detalhe de parte de um barco maior à direita do quadro compõe a moldura. O estilo de câmera muda: o enquadramento é fixo, as linhas de equilíbrio se recompõem, há a preocupação em localizar a personagem inserida no meio, em um contexto, passa-se a um sentido de descrição mais realista, objetiva direta, da perspectiva do olhar de um narrador extra-diegético. A Mulher 2, após um tempo, se afasta do pequeno aglomerado de pessoas e a câmera a acompanha.

Pelo contraste com a figura de uma menina, preta, descalça, que cruza o quadro em primeiro plano, além dos óbvios detalhes até aqui mencionados, visualiza-se, na configuração da iconografia da personagem desta Mulher 2 (Taciana Reis), uma distância ao meio em que está. Seu figurino, o desenho da saia e da blusa, além do detalhe da gravata e do penteado de corte moderno, acentuam os traços da urbanidade já revelados na estrutura de primeiro grau e aqui mencionados e que contrastam com o ambiente dos pescadores. A Mulher 2 não pertence ao lugar em que se encontra, apesar de viver nele, pelo menos nesse determinado período de tempo de sua vida.

À semelhança do que víramos na estrutura narrativa referente à história da Mulher 1, encontramos, também aqui, uma caminhada: a Mulher 2 não está, porém, evadindo-se. Ela está, ao contrário, dirigindo-se à sua casa, retornando. Não é uma caminhada de evasão, como se iniciara o bloco da Mulher 1. É uma caminhada de retorno a uma situação de estabilidade, mesmo que precária, circunstancial, como imagens do futuro da diegese nos darão conta: 
haverá o momento em que não estarão mais juntos. Aquele período de tempo não lhes foi definitivo, mas episódico, relativo, um a mais entre outros.

O estilo de montagem sofre alteração - (como, aliás, na passagem do primeiro ao segundo ato do Bloco da Mulher 1): a extensão dos planos parece querer levar ao extremo a idéia de continuísmo temporal, de se evitar a fragmentação arbitrária do tempo, as elipses temporais, e em procurar, ao máximo, respeitar e reproduzir o acompanhamento literal do fluxo deste continuum temporal. Relações, simetricamente, em oposição ao Bloco da Mulher 1, podem ser detectadas como princípio de orientação estética:

\begin{tabular}{|c|c|}
\hline CAMINHADA DA MULHER 1 & CAMINHADA DA MULHER 2 \\
\hline $\begin{array}{l}\text { Ela se distancia na direção da linha de fuga. } \\
\text { Linhas em perspectiva acentuam a idéia de } \\
\text { distância e orientam para o fundo direito do } \\
\text { quadro. Espaço vazio. Ninguém mais à } \\
\text { vista. }\end{array}$ & $\begin{array}{l}\text { A rua não está vazia: um caminhão entra em } \\
\text { quadro e o cruza na direção da linha de fuga } \\
\text { que, em perspectiva, orienta para o fundo } \\
\text { esquerdo do quadro. O caminhão passa e } \\
\text { descobre a figura da Mulher } 2 \text { que caminha } \\
\text { pela calçada com o cesto de víveres. }\end{array}$ \\
\hline $\begin{array}{l}\text { Uso do “contra-plongée”, da “câmera } \\
\text { subjetiva” que percorre beirada do telhado } \\
\text { contra o céu e, depois, a luz do sol através } \\
\text { das copas das árvores. }\end{array}$ & $\begin{array}{l}\text { Uso do “plongée”, da câmera descritiva, } \\
\text { objetiva direta, que, por cima de ramagens } \\
\text { de árvore, acompanha, descrevendo lá } \\
\text { embaixo, a Mulher } 2 \text { que caminha. A } \\
\text { descrição chega ao nível do detalhamento } \\
\text { dos víveres no cesto: peixes, legumes, etc. } \\
\text { O “Plongée”, no caso, acentua o tom de } \\
\text { fragilidade e desolação da mulher. }\end{array}$ \\
\hline
\end{tabular}

Um corte em continuidade procura dar conta do trajeto da Mulher 2 pelo meio da rua de terra, vazia, em tempo contínuo e integral. Seu caminhar é lento e demonstra, pela postura, um sentido de desolação, de abatimento, reforçado pela paisagem acanhada (rua sem movimento do vilarejo) e pelo som do violino na música escolhida para orquestrar a seqüência. Vê-se que a Mulher se direciona para determinada casa; na parede, a pintura velha, um pedaço do reboco aparecendo. A mulher entra e, novamente, nos deparamos com uma 
porta que se fecha. No Bloco Narrativo 1 das estruturas de segundo grau (episódio da Mulher 1), a câmera não ultrapassava o limiar da porta.

\subsubsection{O outro lado do espelho - a mudança no estilo - a caminho do penhasco}

É como se, neste bloco narrativo (história da Mulher 2), reencontrássemos situações, motivos visuais já visitados no bloco da Mulher 1, de modo simétrico, mas onde os movimentos estão invertidos: lá, a Mulher 1 saía da casa, dirigia-se ao fundo, partia; esta, dirige-se à casa e entra. Como se as duas mulheres, nos momentos que vivem, espelhassem-se uma na outra, sendo ambas partes de uma mesma identidade. Veremos que o mesmo se dará quando na terceira das estruturas de segundo grau, o bloco narrativo referente ao Homem 1.

Entrar com a câmera porta adentro, de modo a ceder ao método de seguir a personagem em tempo contínuo, real, e mostrar a figura do marido bêbado, adormecido, caído no alto da escada, - (nos letreiros do filme, designado como Homem 2) -, mostrar um contracampo para a perspectiva da Mulher 2, colocá -los em relação, “ligá-los” através da imagem de um anel visto em cada uma das mãos respectivas (são casados), assinala para um critério distintivo no tratamento de estilo em relação ao dado no Bloco da Mulher 1 ( o Bloco referente à história do Homem 1 será abordado à frente ) .

Ao prosseguir descrevendo o trajeto da personagem central em seu confronto com o marido bêbado, caído, e depois, pela expressão de desânimo que se desenha em seu rosto, a câmera (e a montagem) retornar ao ponto anterior, diante da porta agora fechada, para mostrar ela se abrindo e, por ela, novamente, a Mulher 2 saindo, como se houvesse desistido - ao menos, por um momento - do marido, observa-se consolidada a evidência de uma narrativa na terceira pessoa ${ }^{27}$ e, nas duas possibilidades de nível de leitura, quer na perspectiva do narrador extra-diegético ou na do intra-diegético (a Mulher 1) - com um sentido de olhar onisciente (o que mobiliza os plongées descritivos, de cima, com a câmera “cobrindo" a Mulher 2 que caminha para casa com a cesta de víveres (descritivo da ação diegética) - ao contrário dos contraplongées “subjetivos” da Mulher 1 nas suas caminhadas - contra os beirais dos telhados e contra as copas das árvores “que correm”, deslizando contra o céu, contra a luz do sol, pontos de vista parciais). Ao contrário do Bloco 1, tecido de condensações

\footnotetext{
${ }^{27}$ Ver nota Geraldo estudo. No penhasco. Geraldo nos fala da sensação de uma alma que quer se desprender da terra.
} 
e elipses temporais através de uma montagem de justaposição, aqui observamos algo que mais se assemelha a um relato de ficção, no tempo linear e cronológico, e no qual, acompanhando a personagem, vemos se desenhar algo mais próximo a um enredo. “Limite”, nesta segunda das estruturas narrativas de segundo grau, é um filme que admite o contra-campo, mostrar o rosto do antagonista, ou do personagem coadjuvante, com autonomia (na designação pelos letreiros, Homem 2).

Mesmo configurando-se, agora, como um modelo mais realista - (acompanhar a personagem em situação local, a câmera de observação à distância) - o desejo de ruptura estética se exibe enquanto forma. Não que o desejo de iconoclastia esteja, nesta parte, ausente. Ao contrário, ele se exibe enquanto forma. Discreto na aparência, introjetado na forma, é ambicioso de alma e caráter. A presença de uma subjetividade, de uma mediação no olhar, persiste. Mesmo que as linhas de fuga, a janela dos enquadramentos, as perspectivas em diagonais, acentuem o dado ilusionista do cinema, a idéia do mundo paralelo que deixou impresso na película o registro de sua imagem e seu tempo em movimento, as intervenções poéticas persistem. Mas para servir ao relato ficcional que está a se narrar no plano objetivo, a partir de um olhar exterior - um cinema de enredo e personagem, numa narrativa continua e linear. Na moldura do formato determinado pelo processo de seguir a personagem em ação, no caso a Mulher 2, o inusitado de algumas angulações ou a duração escandida dos momentos no tempo prestam-se, simultaneamente, a comentários poéticos e a finalidades narrativas. Por exemplo, na alternância radical entre um plongée em plano geral, a câmera acima do nível do poste, da Mulher 2 cruzando com um transeunte e lhe dirigindo a palavra, na rua, lá abaixo, e o contraplongée radical, vertical, do mesmo casal, a câmera colocada entre ambos, de baixo para cima, tendo o céu como teto limitador: o eventual inusitado das angulações, no caso, vale mais pela liberdade na escolha dos ângulos que melhor pudessem traduzir o sentido interno da cena vista: o plongée aberto, além de reforçar, novamente, o índice da eletricidade, ressalta o vazio da rua, a solidão daqueles dois seres que se cruzam por acaso, pequenos, anônimos, e que se conhecem, já que ela lhe dirige a palavra.

Sós, isolados no quadro, cada um no seu caminho, como dois pontos quaisquer cruzando uma geografia vazia e monótona, trazendo a idéia do se viver ao relento na mansuetude exasperada de dias prosaicos e vazios como sugeridos naquele espaço, à mercê do fortuito, do casual, do esquecido. O plongée aberto e cheio de vazios salienta a sensação do acaso e do anônimo. De tão de cima e tão de longe, que não podemos ouvir as palavras que se trocam, se ela lhe comunica algo, ou uma outra coisa, um recado, se lhe pede algo, - somos 
lançados para no meio deles, entre eles, no contraplongée vertical, radical, os dois enormes, acima, a perspectiva deformando as linhas, acentuando o contra-luz e o peso dos corpos, entre eles, em segundo plano, a imagem do poste de eletricidade, o céu acima como teto que tende, no claro, ao infinito.

Quem seria o pedestre, o transeunte? Um amigo que ela tem? Ela lhe comunica algo? Pede- algo? De retorno ao plano geral, novamente, o mesmo plongée anterior, através dos fios do poste em primeiro plano, abaixo, vemos ainda que, após se separarem, cada qual tomando seu caminho, há ainda uma pequena, quase imperceptível hesitação da parte dela, um voltar atrás com alguma idéia. Como se mudasse de pensamento sobre alguma coisa a ser dita, ou se lembrasse de algo, ou ainda, de acrescentar algo. Ela se volta para ele, e diz mais ainda algumas palavras, poucas, curtas, e depois se afasta.

Precisa em estabelecer a atmosfera do encontro casual e que, ao mesmo tempo, constitui-se enquanto ação - pois as personagens se dirigem a palavra e isso faz subentender um desenvolvimento dramático qualquer, mesmo que da ordem do trivial, do prosaico - se a oposição de angulações de forma extrema chama a atenção, temos claro que cada uma delas sintetiza plasticamente o ambiente interno e os sentidos afetivos da cena que presenciamos: o isolamento, as cotidianas e escondidas cumplicidades não reveladas, a melancolia, a tristeza, o desamparo, a solidão das personagens anônimas, pequenas. Ao mesmo tempo, é segura e sintética na exposição da ação em seu desenvolvimento no tempo - enquanto narração descritiva. Aqui, após a evocação do lugar pela montagem de justaposição e síntese, passa-se à descrição cronológica de eventos de ocorrência relacionados no tempo. Acompanha-se o trajeto da personagem central em continuísmo de tempo, de ação, na idéia de reconstituição de um tempo real, de um momento singular que está a ocorrer com ela. O tempo diegético é curto: até o momento, uma manhã ou tarde em que a mulher foi comprar víveres no pequeno comércio na praia e retornou para casa. Dilatado na duração, de acordo com a fluência do tempo interno dos movimentos.

\subsubsection{Da intervenção do narrador}

Na seqüência do afastamento da Mulher 2 na direção de área limítrofe da cidade, novas equivalências de forma com o segmento correspondente no bloco narrativo da Mulher 1 aparecem: ali, tínhamos o plano em que a Mulher 1, saída da cidade, parava por um momento 
diante da estrada de terra sob o calor do sol implacável. A câmera a abandonava para direcionar nosso olhar para a paisagem rústica e devassada que se abria diante dela e ao redor, explicitando o comentário; encontramos, também aqui, na saída da Mulher 2 do vilarejo, na área limítrofe, o mesmo procedimento de câmera: da ordem de um narrador onisciente, extradiegético, que se posiciona diante do que mostra, ou da Mulher 1 (como narradora intradiegética que rememora o contado pela Mulher 2) - e aí, no caso, sua atenção se insinua e se destaca para chamar a atenção para alguma coisa, algum significado a querer estabelecer: a câmera acompanha a Mulher 2 pelas costas, em seu caminhar lento, o rosto inclinado para baixo, levemente encurvada - não é uma postura ereta, de confrontamento - através da estradinha de terra batida. Em segundo plano, vê-se um homem a cavalo, puxando um burro de carga, cheio. Uma criança entra em quadro com um animalzinho nos braços: um pequeno cão. A criança põe-se a brincar com o cão. A Mulher 2 dirige-se para ela, a música no violino rasgando, inclina-se para ela, pousa-lhe a mão na cabeça, num afago, - (como se estivesse se despedindo?), e a câmera os abandona e, numa panorâmica, na mão, vira-se para a direita, e vai enquadrar um cercado de bambus. Avança na direção do cercado, até o detalhe, abaixo, quase ao rés, tremulando contra as sombras do cercado de bambu, frágil, pequena, a haste fina oscilando, uma pequena flor silvestre, que a câmera, aproximando, faz crescer aos nossos olhos. Também aqui, a câmera, de modo similar a no Bloco da Mulher 1, abandona a personagem que segue, para se dirigir para um detalhe ao lado, na natureza, querendo estabelecer uma relação entre a Mulher 2 e a pequena flor despetalada.

Estes planos - (e no terceiro dos recuos no tempo - História do Homem 1 encontraremos outro equivalente em forma e função, como veremos) - sintetizam, num só procedimento, fazendo confluir, os três níveis da narração presentes no filme: o ponto de vista do narrador extra-diegético, a se considerar o discurso do filme incluída sua moldura (no caso, como num fluxo de consciência), e os intra-diegéticos, quer o gerado pela moldura (olhos da Mulher 1), como aqueles gerados em cada um dos recuos no tempo a partir da grande estrutura narrativa de primeiro grau. Cada um deles, em cada um dos blocos narrativos onde se situam, são pontos de ápice, nos dois primeiros casos, ou de início, no terceiro caso, entre dois segmentos onde ocorrem mudanças no estilo, em particular, no que se refere ao tratamento do tempo. No bloco da Mulher 1, como vimos, é ponto culminante do segmento da “partida” da Mulher 1, que terá ainda um plano de “fechamento-conclusão" (o plongée acentuado dela indo-se ao fundo do quadro, na estrada de terra batida, a câmera no nível da altura do poste) e mudança para ao segmento seguinte onde ocorre a alteração de natureza de 
tempo: a seqüência do quarto da costura, onde o tempo remete a um período maior condensado em um momento que o exemplifica. Agora, no episódio da Mulher 2, igualmente, antecipa o plano de “fechamento-conclusão" da seqüência do afastamento da personagem na direção do penhasco, marcando passagem para o segundo segmento deste mesmo ato, que é o momento dela no alto do penhasco, onde a dilatação temporal do instante é o que a orquestrará.

O plano de "fechamento", conclusivo do afastamento da personagem da cidade na direção do penhasco, é - como no correspondente ao Bloco da Mulher 1 - de um plongée acentuado, em plano geral: a Mulher 2 é vista igualmente de um ângulo radicalmente alto, um cercado de varas, como o que víramos, em manchas de sombras estriadas, por trás da flor com a qual a câmera estabelecia uma comparação. Agora, a vemos do alto, com uma linha de separação que corre inclinada, obliqua, atravessando o quadro na horizontal, cindindo, separando, em segundo plano, do lado de lá do cercado, a Mulher 2 que caminha, cabisbaixa. No chão de terra, projetada pela luz do sol, a sombra de um urubu que cruza os céus (em off, pois o que vemos é a sua sombra) projetada no chão de terra. Seu movimento é no sentido contrário ao da mulher.

\subsection{No penhasco - tão a sós, quanto num quarto de costura}

Se fizermos um traçado da curva dramática do filme em seu todo, observamos que o ponto mais alto, que se situa em um vértice, destacando-se do conjunto, é a que segue: a Mulher 2, do alto de um penhasco, o olhar voltado, em vertigem, para baixo.

A sombra do urubu, vista anteriormente, que passara cruzando o chão de terra, evocanos a imagem da colina, vista na cena de abertura do filme. Na tela, agora, a imagem da colina emerge, vinda de trás, do fundo. No topo, minúscula, uma figura humana que, por aproximações sucessivas, identificamos como a Mulher 2.

Filmada em contra-plongée, os cabelos revoltos que, no início, lhe cobrem rosto, escondendo-o no contra-luz, recortada a figura contra o céu claro, no movimento do olhar na direção do alto, em expressão de terror, seu rosto se ilumina. Um desespero. A câmera avança, até seu rosto, afundando na imagem, perdendo o foco na visão. Como se traduzisse sua vertigem, a câmera faz movimentos de giro em trezentos e sessenta graus, revirando a paisagem ao fundo, o largo de uma orla vazada, áreas semi-desertas, o horizonte difuso, o 
vilarejo ao fundo, sumido no cinza. Os movimentos vertiginosos da câmera sobre esta paisagem que é aberta, vazada, rasgada, sem outros picos elevados a quebrar a amplitude do horizonte (a Mulher 2 está acima de tudo e de todos), ao mesmo tempo, malgrado a angústia do presente, nos dão a sensação de uma flutuação, de vôo e desprendimento ${ }^{28}$.

Paradoxalmente, essa pode ser a sensação da personagem, mais precisamente, a manifestação de um desejo de querer se despreender da terra, libertar-se da condição de vida miúda, oprimida. A sensação se confirma se consideramos que o plano que emerge, logo após os movimentos giratórios de flutuação da câmera sobre a paisagem ao fundo, através de uma lenta fusão que faz com que ele se afirme com precisão monolítica de foco diante do borrado do final do plano que o antecede, é o de um conjunto visual onde metade do quadro, em sua parte inferior, é ocupada pelo chão de pedra do penhasco, e a outra metade, superior, pelo vazio do céu. Pontuando, no nível da linha divisória entre as duas metades do quadro, - a linha da superfície do chão de pedra de que se compõe o topo da colina, - encravada, pequena no quadro, - assim como o barco sobre a camada de superfície gelatinosa das águas do mar, a figura (humana) da Mulher 2. Na linha de perspectiva do quadro, sua figura não é só coberta por um detalhe, como fica proporcionalmente inferior em altura ao lado, e logo atrás, em segundo plano portanto, de um cacto espinhoso solidamente encravado no solo. A solidez sugerida pela massa compacta e mineral do chão, no qual a planta de folhas pontudas e duras, e que sugerem aspereza, está encravada, ao lado da Mulher 2 que aparece sentada, como se plantada, trazem-na de volta à sua condição terrena. O desejo de flutuação é inútil. Tudo a devolve à terra. À sua vida pequena, sem perspectivas, sem sonhos

O momento da Mulher 2 no alto do penhasco é único e de reflexão. Por analogia e equivalência simétrica, corresponde, no que se refere ao bloco narrativo da Mulher 1, à seqüência do quarto de costura. São aqueles momentos em que vemos as personagens nos seus estados de isolamento, de recolhimento num espaço que lhes é próprio: claustrofóbico, no primeiro caso, a sensação de aprisionamento persiste no segundo, apesar da imensidão da paisagem (do alto do penhasco, tendo o céu acima e o mar abaixo). É o instante da personagem dilatado ao seu ponto máximo.

\footnotetext{
${ }^{28}$ Há diferença entre as duas versões. A se considerar a existência do plano em reprodução fotográfica no mapa, apesar da ausência na cópia em vídeo, opto por considerar a versão mais completa, uma vez tendo comprovada a existência do plano faltante. Ademais, é coerente com a lógica de estruturação do filme, como temos visto, bastante repleto de relações por simetrias, em analogia ou oposição, repetições como estabelecimento de freqüências e andamentos rítmicos, dualidade nas relações e sentidos engendrados.
} 


\subsubsection{No penhasco - tão imobilizada quanto as três personagens no barco - uma estrutura de terceiro grau - equivalências com a estrutura narrativa de primeiro grau}

No que se refere ao tratamento do tempo e seu modo de representação, esta seqüência constrói-se como a própria estrutura narrativa de primeiro grau da qual se origina: as três personagens no barco, no meio do oceano.

A Mulher 2 encontra-se em ponto de repouso, de imobilismo aparente. A circunstância é propícia a ruminações, a digressões, rememorações.

Enquadrada em plongée, a câmera sobre ela, em plano médio-próximo, de costas, sentada, no declive do penhasco diante do mar, a blusa branca projetando-se a partir do ângulo inferior esquerdo do quadro, servindo como base para o impulso do movimento das linhas do corpo na direção do canto superior direito do quadro, - como uma seta - ela pensa.

Assim como na estrutura narrativa de primeiro grau, a condição de imobilidade no barco levava às ruminações do passado, gerando as estruturas de segundo grau, aqui, igualmente, o estado reflexivo da Mulher 2, parada, no alto do penhasco, diante do mar, leva, através da superfície das águas - ( a câmera, em panorâmica, segue a direção da inclinação do corpo da Mulher 2, sentada, para a superfície das águas diante dela) -, que, agora, passam a ocupar todo o quadro, refletindo os pontos de luz brilhantes do sol, e de onde, gradualmente, outra vez, emergindo do passado, da mente, surgem detalhes da imagem do marido roto: suas mãos sobre o teclado do piano, o rosto filmado em contra-plongée que ressalta o desleixo da barba por fazer, os sapatos furados, de maltrapilho, o detalhe de um cálice de aguardente em fundo neutro, nítido sinal impresso na mente, como no negativo, o brilho que reflete em sua base de vidro ou cristal, a mão que retira o cálice e o repõe vazio (o ato de beber em off ).

Detalhes que recompõem a figura do marido na mente da Mulher 2, e que logo desaparecem novamente, submergindo sob a superfície das águas do mar, se apagando, no inconsciente, para que a câmera faça a panorâmica de retorno, desta vez, do mar para o penhasco, onde a reencontramos parada, a Mulher 2, parada, sentada, inclinada, cravada no chão do penhasco, como a árvore cujo tronco também se inclina, como ela, na direção do mar. O princípio de construção que refaz o pensamento da Mulher 2, referindo-se à imagem do marido em ruínas, é o mesmo de justaposição de detalhes que recriam um conjunto na mente 
de quem os recorda, e é através, como sempre, da superfície das águas do mar que estes detalhes imersos em um passado esquecido, submerso, vem à tona ${ }^{29}$.

Assim, dentro deste ato no segundo dos flashbacks do filme, encontramos uma nova analepse, um novo desvio de tempo, podendo-se dizer que, aqui, nesta segunda das estruturas de segundo grau, encontramos a outra, pequena, de terceiro grau. Se observamos, esta seqüência ocupa, quanto ao tempo físico, o final do primeiro terço do filme (de um total de 1h:55 aproximados, situa-se em torno dos 00:40:00. Na equivalência simétrica, ocupando outro ponto culminante, de destaque, encontramos o plano em que o Homem 1 cai prostrado no chão de lama e a câmera sobe aos céus (em torno dos 1:27:00h) no bloco narrativo referente à história do Homem 1. Estruturalmente, fecha-se o círculo de construção por simetrias.

O tratamento visual distintivo reservado ao pequeno interstício na cena do penhasco, onde se trabalha exclusivamente com índices da figura do marido roto (mãos nas teclas do piano, sapatos furados, cálice de aguardente) e que recompõem sua figura na mente da Mulher 2, dura apenas o instante dessa rememoração e se explicita por ela (as imagens metonímicas do marido são projeções da mente da mulher), retornando-se a seguir, à narrativa descritiva, na terceira pessoa, a partir da perspectiva de um olhar onisciente do narrador extra-diegético e de uma fotografia e decupagem de estilo realista: um plano da luz do sol escondendo-se por trás das nuvens revela o fim do dia que se aproxima. Aos poucos (a duração do plano é lenta), anoitece. Termina-se assim a primeira parte deste segundo ato, segundo movimento, da segunda de nossas estruturas narrativas de segundo grau que é o Bloco da Mulher 2.

\subsection{A figura do outro (o Homem 2) - nova mudança no estilo}

Caindo a luz do dia, já na cidade, distingue-se um beco. Nele, vê-se a figura do marido (o Homem 2, Brutus Pereira) vindo do fundo. Caminha de modo um tanto trôpego, é um andar displicente, não retilíneo, não direcionado, como se estivesse um tanto ao léu, indiferente a circunstâncias externas. Vem pela calçada e sua caracterização difere das dos

\footnotetext{
${ }^{29}$ Notas sobre Antonio Campos. Sétima Arte, um culto moderno. Mulher 2, a figura do outro. Acrescente-se, aqui, a tipologia de classe melhor definida e a locação, o que o faz se aproximar de um realismo melhor caracterizado. Vale estudo a se desenvolver que o aproxime com a estética de Murnau e Jean Renoir e o fato de que, nesse momento, ainda, não existia o que viria a se formular como o neo-realismo.
} 
demais personagens: sua capa e chapéu, a barba por fazer (visível quando chega mais próximo à câmera), remetem à figura de um típico social de gênero cinematográfico, mais do que de realidade (a capa escura, o chapéu), ao contrário do que ocorre nos demais, como visto, que querem evitar justamente tipologias sociais ou regionais ou de convenções de gêneros.

Ele vem até primeiro plano e parece notar, ao acaso, algo no chão da rua. Vai até lá e inclina-se para apanhá-lo. A câmera mostra, em detalhe, o que era: uma ferradura. Olha para ela, avalia e, displicente, torna a devolve-la à rua. Coloca a mão no bolso e sai de quadro, a câmera sustentando, ainda um tempo, a imagem da rua vazia.

O plano seguinte, novamente o plongée (câmera alta) e o enquadramento aberto, em plano de conjunto, deixa ver o cuidado em nos dar uma visão geral do espaço com respectiva localização da personagem, mostra-nos a fachada de construção antiga, portas estreitas de madeira, em cuja calçada vê-se o "marido” (o Homem 2) entrar em quadro e caminhar. A câmera segue em panorâmica lateral descritiva, descobre a fachada de um cinema, pequeno, de vilarejo, com cartazes onde avista-se um dos títulos dos filmes anunciados: "O Homem sem Rosto”. O marido (Homem 2) entra nesse cinema.

Pode-se dizer que, nesta seqüência, o filme, em seu tratamento descritivo, pela decupagem novamente em perspectiva horizontal, cronológica, os enquadramentos em diagonal, evitando a frontalidade das pessoas e coisas em relação ao eixo da câmera, pelo respeito às regras de ilustração de uma idéia de continuidade de ação e contiguidade espacial, pela luz, agora com sombras que procuram dar a ambiência do lugar em um determinado tempo natural e situado ( o findar do dia, o beco mal iluminado), pela preocupação em apresentar didaticamente, ilustrativamente, o espaço da diegese e, nele, introduzir a personagem (o marido da Mulher 2), personagem que vem a ser o foco narrativo deste terceiro ato neste Bloco da Mulher 2, atinge nuances de um naturalismo típico, inusual no filme em seu conjunto.

Nos dois primeiros atos deste Bloco, já pudemos observar, este procedimento mais descritivo-realista, onde a presença de um narrador extra-diegético se acentuava, já estava presente. Mas, mesmo ali, a ocupação em elaborar o tempo interno a cada momento, em prolongar a duração dos planos para se conter uma determinada unidade mínima de experiência da fluência do tempo e do ritmo interior (pulsão), além de acentuar a atmosfera de melancolia, de desolação das personagens, no caso a Mulher 2, ainda trazia, em si, mobilizado, um diálogo com experiências estéticas do cinema vinculados à vanguarda (os estudos do tempo). Aqui, a narrativa se ocupa em fazer, basicamente, o relato fluir no tempo, 
sem ruídos nos seus modos de representação que venham quebrar a idéia de um ilusionismo, em colocar a personagem em movimento, a ação física em andamento, de forma ilustrada, em um tempo e um espaço objetivamente situados, circunstanciados, contextualizados. Aqui, desenha-se de modo mais explícito, o que poderíamos chamar de ilustração do desenho de um enredo, de uma intriga de teor literário.

Esteticamente, no filme, o diálogo vai ao encontro da outra tendência, como sabemos bastante mais acentuada no Brasil (e no mundo) do período, o modelo de representação naturalista tal como o apontado por Edwin Porter e David Griffith, no cinema americano. No Brasil, em estilo, aproxima-se de um José Medina (ver a ressonância da figura do marido da Mulher 2 com a do vagabundo de "Fragmentos da Vida”, 1927), ou mesmo Humberto Mauro, Adhemar Gonzaga, os modelos de roteirização de Antonio Campos, que aspiravam ao cinema narrativo clássico dramático de ficção ${ }^{30}$.

O tratamento minimalista, de se filmar apenas índices, signos metonímicos para designação de um todo, é retomado mas não de modo tão indireto, radical e reflexivo, como nos detalhes da figura do marido recortados e situados em espaço de contingência atemporal, como na cena em que a Mulher 2, sentada no topo da colina, fazia vir à tona através da superfície das águas do mar. Ali, os detalhes não apresentavam um fundo que se referisse a um contexto geográfico, espacial, específico e determinado: as mãos tocando o piano, o rosto barbado em ângulo oblíquo, os pés em sapatos roídos, o cálice, supostamente de aguardente, sendo retirado e devolvido vazio, surgiam imersos em fundo neutro, como detalhes nítidos, “chapados”, tendendo à frontalidade bi-dimensional de uma natureza morta, ressurgidos em uma mente.

Aqui, encontramos apenas uma cadeira situada ao lado de um pedestal para a partitura. Mas há uma parede nua por detrás, a iluminação sobre ela faz destacar os objetos do fundo, acentuando o volume, criando a ilusão de um espaço em terceira dimensão, físico, real, tridimensional, verdadeiro, onde o neutro em volta, na outra seqüência, tendia a levar a um quase abstracionismo, uma imagem da ordem do mental, do virtual.

Não vemos a figura do marido pianista, mas sua sombra, projetada na parede, sobre os objetos que, no fundo, ajudam a compor sua identidade (partituras) assim como os elementos de sua indumentária, adereços inclusive (jornal, casaco, chapéu) que são atirados por ele, fora

\footnotetext{
${ }^{30}$ Notas sobre Antonio Campos. Sétima Arte, um culto moderno. Mulher 2, a figura do outro. Acrescente-se, aqui, a tipologia de classe melhor definida e a locação, o que o faz se aproximar de um realismo melhor caracterizado. Vale estudo a se desenvolver que o aproxime com a estética de Murnau e Jean Renoir e o fato de que, nesse momento, ainda, não existia o que viria a se formular como o neo-realismo.
} 
de campo, em off, sobre a cadeira. Vê-se a sombra da figura humana do pianista sair de quadro e, depois, a tela branca de um cinema, vazia.

Novamente, um escuro que ocupa a tela toda e, somente após a tela preta, metaforicamente nos lembrando que o próprio filme Limite inicia-se desta forma (a tela preta com a música), vêem-se as primeiras imagens do filme que se inicia a projetar no cinema do espaço, agora, da ficção: “Carlitos encrencou a zona”, no original, “The Adventurer”, 1917, de Charles Chaplin.

Os planos-índices, recortados metonimicamente na seqüência rememorativa da Mulher 2 no topo do penhasco, no ato anterior, referiam-se à composição de um conjunto maior que seria a identidade do marido, na perspectiva do ponto de vista daquela mulher. Agora, os elementos mínimos do cenário, deixando o corpo do marido fora de campo (em off), mas, pela sombra, identificando sua presença ao lado, na contigüidade do espaço, apresentam por elipse, agora não temporal, mas espacial, com economia e depuração de encenação, a continuidade do movimento da personagem que estamos seguindo, o Homem 2 (marido da Mulher 2), desde o momento em que vem pelo beco, e se dirige ao seu local de trabalho, o cinema, onde musica as apresentações dos filmes.

Os gestos com que vemos as peças de sua indumentária - casaco, chapéu e o jornal serem lançados, um a um, sucessivamente, sobre a cadeira, com a ausência do sujeito em campo - (como já mencionado, ele está em off, somente sua sombra projetada sobre, em campo) para que depois vejamos a sombra de seu dono se retirar, acentuam algo de um movimento mecânico, indiferente, displicente, por trás (como a ferradura, símbolo da boa sorte, fora deixada de lado na rua - um entulho, um resíduo), como se um movimento desinteressado, sem vontade, sem alma.

Tal sugere a figura do marido da Mulher 2.

\subsubsection{O filme dentro do filme - um pequeno comentário}

Fazer alusão ao próprio cinema, a se tratar de um filme, não é novidade e tão pouco o era no período. As experiências metalingüísticas proliferavam e, mesmo em um pequeno

filme de David Griffith, Those Awful Hats, 1909, encontramos, como situação, acontecimentos dentro de um cinema onde se projeta um filme. Obviamente, em Griffith, não 
há nenhuma intenção iconoclasta como, por exemplo, no projeto de Dziga Vertov, onde se buscava revelar os mecanismos do modelo de representação ilusionista no cinema. Aqui, em Limite, o filme dentro do filme encontra-se confortavelmente instalado em sua narrativa, prestando-se, entre outras funções, a de designar a composição e identidade da personagem.

Podemos acrescentar ainda, no caso, que o filme projetado dentro do filme, é mudo. $\mathrm{Na}$ época em que presumivelmente se passa a nossa história, no mundo, o sonoro já se encontrava em avanço. Mesmo que, na época, como sabemos, houvesse ainda os defensores do silencioso contra a deterioração artística que o som pudesse trazer ao cinema enquanto forma de expressão específica,, em realidade, o que se colocava em andamento era a extinção de um determinado modelo de exibição, de espetáculo, e de profissão. Todo o ritual expresso na seqüência que segue, - e que se ocupará em mostrar esse marido em suas atividades diárias, com os risos ingênuos do seu público, é um ritual que se encontra condenado ao desaparecimento.

\subsubsection{De volta ao pseudo-iterativo - a paisagem humana}

A seqüência a seguir encontra-se em continuidade de movimento e descrição do trajeto da personagem do marido da Mulher 2: o Homem 2.

Após termos visto sua chegada ao local de trabalho, o cinema, a montagem prossegue ainda no estilo descritivo: dá-se o início à projeção.

É curioso o detalhe de que as duas inserções de mensagens presentes no filme mediadas por um dispositivo de comunicação de massas - a notícia impressa no jornal folheado pela Mulher 1 e, agora, o filme de Chaplin - referem-se a episódios de motivos policiais: fuga da prisão. No filme de Chaplin, a cena projetada dentro do filme, como se sabe, é a do "vagabundo" que, vestido como presidiário, as roupas listradas, emerge de um túnel construído para fugir. O túnel, inadvertidamente, fora dar em um banco de areia, possivelmente numa praia, ao lado de um gordo policial que cochila. O "vagabundo” acaba fugindo numa cena cômica, em que o gordo policial, desajeitadamente, mal se equilibrando em seu corpo, cai para trás.

Em termos metafóricos, pode se dizer que neste segundo recuo no tempo, no filme exibido dentro do filme, o “vagabundo”, para o Brasil, na verdade, Carlitos, acaba realizando 
“na praia” o que no Bloco narrativo da Mulher 1 não se realizava, de fato, no interior dos planos, apenas em uma das relações possíveis estabelecidas pela montagem.

O que se segue é uma seqüência que permite, gradualmente, sair do descritivo naturalista e regressar ao tipo de condensação poética já exibido nas “evocações dos lugares” aqui analisadas.

A música de Eric Satie retorna, na sua cadência de repetições, e o detalhe dos dedos do Homem 2, nas teclas do piano, inicia a série de planos da platéia rindo: são detalhes, basicamente, dos dentes que se abrem nesses risos, dentes imperfeitos, humanos, que se opõem em linhas diagonais. Às vezes, um plano em conjunto, de uma única fileira de moças, simples, vestidas para o lazer social, as golas com babados, alinhadas em perspectiva no meio da penumbra: um plano que volta, repetindo-se, alterando com os closes dos dentes. Servindo como suporte e pontuação entre esses dois núcleos de imagem, o plano do pianista (em plongée ) e o de um espectador adormecido, a barba por fazer (à semelhança do pianista), o palito entre os dentes, filmado em um ângulo oblíquo: um plongée vertical, de cima para baixo, de seu rosto em detalhe, de modo que ele fique deitado no campo de visão, a fronte no ângulo inferior esquerdo, o queixo alongado voltado para o ângulo superior esquerdo do quadro

Essas imagens se alternam, como música - (a própria música de Satie comentando a seqüência) - em estrutura semelhante à já vista, por exemplo, na seqüência da fonte de água, o chafariz, na primeira parte deste bloco narrativo: aqui, dois planos de homens, funcionando como eixo - o do pianista (Homem 2) e o do espectador - ao redor dos quais se organizam e se compõem os planos dos dentes e das moças que riem. Nela, voltamos a reencontrar um tempo diferente ao até aqui desenvolvido, nesta segunda das estruturas narrativas de segundo grau, como abordaremos adiante.

Recompondo: se na história da Mulher 1, tínhamos pedaços de largos períodos de sua vida condensados e justapostos, aqui, temos o tempo diegético de um dia ou de uma tarde a 
caminho do crepúsculo, em que ocorre o momento descrito acima: a mulher volta das compras, vê o marido e se retira para o penhasco.

Há, inclusive, a idéia de um simultaneísmo de acontecimentos no tempo, através do recurso da montagem paralela, no momento em que se opõe à seqüência da Mulher 2 no topo da colina, imersa em seus pensamentos, a do marido que caminha na direção do cinema: um plano, do sol se escondendo por trás das nuvens, inserido logo após o final da seqüência da colina, é o que faz a ligação com a seqüência do marido, já à noite, vindo por um beco a caminho do cinema onde trabalha.

A seqüência que nos fala da personagem do marido da Mulher 2, pianista de cinema e com tendência a beber que, pelo estilo de encenação naturalista, à primeira vista, deixa sentir a presença de um narrador extra-diegético interessado em acompanhar este personagem (em sua miséria, consegue orquestrar o riso e a alegria das pessoas simples do vilarejo), vista à luz da Mulher 2 que é quem, de fato, no barco, narra sua história ao Homem 1, apresenta grau de equivalência com a seqüência final do Bloco 1 - as imagens da cidadezinha da qual a Mulher 1 quisera fugir.

A paisagem da qual a Mulher 2 está fugindo, diante da qual não consegue conter seu sentimento de repulsa, não é geográfica, como no caso da Mulher 1 (o mundo pequeno daquele vilarejo perdido no êrmo): é humana. É o marido, com todos os detalhes característicos de sua ruína, que se fixam de forma nítida na sua memória: a embriaguez, a barba por fazer, os sapatos furados, rotos, o estado do descuido absoluto para consigo mesmo. E cerrado em seu mundo de tocar piano no cinema, animar os filmes para que a platéia, de gente ingênua, humilde e simples. Esta seqüência é da mesma natureza da seqüência da Mulher 1 diante da máquina de costura: remete a uma iteração de eventos de mesma ordem e natureza que estariam a se repetir indefinidamente ao longo dos dias, dos meses e, quem sabe, anos, em um ritual do cotidiano que acaba por oprimir as personagens (no caso, Mulher 1, Homem 2, e agora, especialmente, a Mulher 2). É uma seqüência singular, pois está ocorrendo naquele momento, mas que remete ao iterativo, ao freqüentativo. Uma narrativa sumária que se faz, no caso, única, exemplar, paradigmática de uma condição: simbólica, uma seqüência pseudo-iterativa ${ }^{31}$.

As demais seqüências (à exceção, obviamente, do plano final aqui mencionado - porta e janela fechadas - que é emblemático da situação exposta no episódio, como o é a moldura

\footnotetext{
${ }^{31}$ Pseudo-iterativo. Gerard Genette.
} 
inicial do filme para o seu conjunto), se verificamos, compreende um período bastante curto de tempo: um dia, no máximo, a se considerar que a luz do início deste bloco é matutina e a do final, no crepúsculo. Ao contrário do Bloco 1, onde compreendíamos unidades de grandes períodos de tempo (partida, viagem, outra cidade, nova partida, etc) em pequenos sub-blocos de seqüências condensadas em uma narrativa elíptica promovida pela montagem, neste, temos unidades de curto tempo diegético (a extensão de um dia até o cair da noite) ganhando corpo, desenvolvendo-se na continuidade de seu tempo interno, dilatando-se de forma a ocupar a maior parte da estrutura do todo. Estamos cumprindo o percurso que vai do cinema da montagem ao cinema da distensão do tempo em sua duração interna, ao cinema do tempo interior, o tempo dentro do tempo.

\subsection{O tempo da repetição - o iterativo}

Ainda uma pergunta nos fica: naquele dia em que ela voltara da compra dos víveres na praia e, ao se deparar com a imagem do marido bêbado, adormecido no topo da escada, não conseguindo ir adiante, voltou atrás e tomou o caminho do topo do penhasco... - foi indicativo de uma partida, um abandono, ou apenas a repetição de mais um dos muitos momentos em que aquilo já se lhe sucedia, como agora, mas no qual tudo terminava ali, naquele mesmo lugar para onde ela costumava ir - ou fora naquele dia, - apenas em mais um de seus muitos momentos de desespero diante de uma situação que lhe custava romper?

Na escada, seu gesto de reclinar a fronte no punho cerrado, em profundo cansaço, indicava um esforço enorme para resistir ao que quer que estivesse se passando em seu interior.

Cada momento, em sua singularidade, traz imanente a contaminação de um conjunto maior de estado de coisas que o rodeia. A parte está contaminada pelo todo, é expressão desse todo. O ritmo próprio ao da Mulher 2 - ao contrário do que se passa com a Mulher 1 que é sempre o ritmo de avançar a partir de uma fuga/partida empreendida (personagem ativa, de sentido teleológico de mundo, sem apego ao passado) - é o ritmo de uma certa circularidade de quem demora ainda a se depreender de seu mundo, pois demonstra, por ele, um apego que a Mulher 1 não tem.

O que pressupõe algo da natureza do maníaco, da repetição: reafirmação cíclica de uma condição da qual não se consegue romper, um dos temas no filme. 
Por isso, naquele fim de tarde, no penhasco, ela aparecera tão firmemente cravada naquele solo, diante do abismo, tão cravada como aquele arbusto ou a árvore reclinada no barranco. Por isso, a aparência de fragilidade maior que emana de sua figura que traduz a visão romântica e idealizada do belo feminino a partir de um olhar neo-platônico.

\subsection{O epílogo}

O plano da porta, na fachada da casa desse casal, vista, agora, fechada. A panorâmica da câmera leva até a janela, de vidro, quadriculada no batente, do mesmo modo, fechada. Como a maioria das casas que aparecem nos vilarejos do filme. Fechadas, como de habitantes fantasmas, diluídos na paisagem. No filme, observamos, o humano ocupa mal os lugares. Aparece nos poucos indícios, entre pedras, areia, água e vegetação: um homem, uma mulher, um sinal do que se passou por ali, o poste que conduz a eletricidade pelas paragens desertas. A casa, agora, está fechada, foi deixada para trás. O casal se foi. Ou foi ela quem se foi. Ou estarão, ainda, ausentes: ela continua no penhasco, ele, tocando piano no cinema, numa freqüência rítmica indeterminada, numa dilatação temporal que tende à suspensão do momento, tornando-o paradigmático, simbólico de um ritual que se estabelece como padrão de referências para aquele período, remetendo a um tempo cíclico e, portanto, mítico. A indefinição paira, é o que move as personagens, o que sobrou delas.

Pensamos no momento em que eles teriam chegado àquela casa, nas vidas que teriam passado ali. Esta casa, agora, lacrada, vazia. A textura da parede envelhecida, com manchas, a porta de madeira, o batente da janela fechada, tudo leva a um processo de humanização das coisas: ao vermos a porta e a janela, a fachada de sua casa, na verdade, estamos vendo o casal, a imagem do casal que se foi, e do qual só temos sua imagem em nossa memória.

A casa, a porta e a janela cerradas, designativo de personagens de destinos fracassados, que “deram errado”, frustrados em suas tentativas.

Como, naquele vilarejo ermo, designativo da Mulher 1, onde víamos as janelas batidas pelo vento, a porta de madeira, as folhas abertas, ao léu, abandonadas de vez por ela, a Mulher 1. Aqui, porta e janelas fechadas, como lacrado, inteiriço, o vestido preto da Mulher 2. 


\section{BLOCO 3 - A HISTÓRIA DO HOMEM 1}

\subsection{O homem, a mulher e a paisagem - o tempo passado}

A terceira das estruturas de segundo grau, correspondente à história do Homem 1, é a mais extensiva na duração do tempo físico do filme, ocupando, no conjunto, quase sua metade (em um total de 1h 55min de filme, inicia-se em torno dos 00:51 minutos).

Sua primeira parte, nos apresenta, na voz da personagem do Homem 1 (neste bloco, narrador intra-diegético), imagens dos momentos em que ele teria se encontrado com uma mulher, cujo rosto igualmente não vemos, e da qual nós teremos apenas sua figura (equivalente à figura do “outro” no Bloco 1, confundível - e condensada - na figura do “carcereiro”). Esses momentos são evocados do passado, pela mente da personagem, através de sua fixação no detalhe dos dois gravetos que manipula: a câmera subjetiva do Homem 1 nos dois gravetos assinala o ponto de onde emergirão suas lembranças ${ }^{32}$.

Na tela, o detalhe (os dois gravetos manuseados nos dedos) evoca a imagem do casal que surge, nesse primeiro momento, como integrado a uma paisagem, se paradisíaca, (por se tratar de imagem de presença da natureza, aparentemente intocada pelo homem - uma orla marítima, um quadro que tende ao infinito pela linha dos morros baixos longínquos, o céu ainda claro pelo sol que se põe, as nuvens que emolduram o quadro) - por outro lado, um tanto bucólica, e triste, pois vazia dos seres vivos, onde habita apenas a vegetação descuidada, o capinzal vazio, varrido pelo vento, os parasitos inertes, grudados sobre troncos ressequidos, a árvore de galhos secos, um lago escondido entre o mato desordenado, um coqueiro solitário, um poste elétrico, e ruínas de uma construção em arcos, dominada pela vegetação selvagem.

O casal surge no princípio, de forma difusa, visto apenas pelos detalhes de suas pernas, - (calçado, vestido, ele com calças e sapatos, ela com vestido, meias e sandálias de desenho clássico, fechada, discreta) - pouco a pouco, se definindo, suas pernas caminhando

\footnotetext{
${ }^{32}$ As semelhanças de método de Limite com Marcel Proust, o autor de Em busca do tempo perdido, bem como com a bibliografia que compreende aspectos da memória e do tempo no ato da experiência humana, não é elemento colocado em evidência nos estudos sobre o filme. Mas a aproximação é inegável e, neste caso, em se tratando de cinema, vemos uma explicitação didática do método: o detalhe que faz ressurgir o passado como uma coisa viva. De resto, apesar de Mário não mencionar Proust, ao menos no material que tem vindo a público através do trabalho de Saulo Pereira de Mello, é notória sua admiração por Virgínia Woolf, em especial no que se refere a "The Waves" (As Ondas), escritora que, como sabemos, ao lado de Proust e Joyce, nos trouxe a linguagem do fluxo da consciência incorporada às narrativas, tal como, no cinema, ambicionava o projeto de Eisenstein.
} 
junto à orla, apenas os pés em quadro, que desaparecem, por fusão, cedendo ao avanço da câmera, qual uma consciência vigilante no detalhamento do que lhe vêm à memória, e que apontam, desta vez, apenas, para as pegadas na areia. Depois, contra o céu, suas mãos juntas, solidamente unidas, destacadas.

Na trilha, acordes musicais sugerem tensão, anúncio de alguma coisa que está para acontecer. Sobre as mãos unidas do casal, a câmera apontada contra o céu, uma mancha escura, aos poucos, por fusão lenta, começa a surgir: a mancha preta se define na imagem, em contra-luz, do tronco de madeira nua de uma árvore, que cruza o quadro na horizontal, a linha ascendente para o lado esquerdo do quadro., sendo comido por um parasito que se encontra, ali, incrustado.

A sós, no vazio do campo, o casal.

Em um plano, a perspectiva deixa vê-los levemente afastados um do outro, desenhado cada um na sua individualidade: ela tem a cabeça inclinada para baixo, lembrando, em muito, a figura da Mulher 2. Sua figura, aparecendo através da fusão, nasce por um instante confundindo-se e se impondo sobre a imagem do parasito que se alimenta do tronco morto. $\mathrm{O}$ homem, as pernas ligeiramente abertas, a coluna ereta, sua cabeça olha para frente mas, pela perspectiva no quadro, parece olhar para o alto, uma figura mítica, de quem almeja com o olhar. Em outro plano, os vemos mais juntos, duas figuras pequenas mais à direita do quadro, destacadas contra o vazio do horizonte, na linha que divide o campo em sombra, no contraluz, ocupando a parte inferior do quadro, cindido da claridade do céu aberto que se impõe diante deles.

Depois, pelos pés, o casal deixar, furtivo, seus sapatos e meias na relva rústica para, em seus braços, suspendendo-a, ele conduzi-la através da água do lago. Na natureza em volta, o coqueiro, o poste, parados, isolados, indiferentes, como indiferentes eram os objetos de costura da Mulher 1 face ao seu abatimento. Os indícios do casal, abandonados na relva, continuam lá: sapatos e meias jogados.

Ele volta com ela em seus braços, somente os vemos pelo detalhe das pernas, nunca seus rostos. Eles estão juntos, mas em volta, na natureza, insiste-se na figura de uma árvore ressequida, em ruínas de construção antiga, tomadas pela vegetação, e que evocam vidas e histórias ali vividas. Um cacto, selvagem e ríspido, fincado na diagonal sobre a areia. Eles estão juntos, mas estão sós, absolutamente sós. Em volta, a natureza acena com o silêncio e o 
vazio. E os tristes sinais, como evidência de presságios: o parasito grudado, como doença, no tronco seco; as ruínas sendo comidas, pouco a pouco, pela vegetação.

O tempo dilatado dos planos que surgem como quadros e momentos, que se sucedem em fusões num fluxo de memória e pensamento em processo, expõem-nos uma condição, um estado de coisas. São cenas que parecem querer se referir a um período de uma vida passada, onde aquele casal de amantes ter-se-ia encontrado naqueles lugares, afastados, isolados do olhar humano, tendo como testemunho apenas a natureza. Amor escondido.

A condição da liberdade individual, de se ocupar um espaço privativo onde o ser seja senhor de seu tempo, revela-se limitada, provisória, precária: no caso do quarto de costura, para a Mulher 1, do penhasco para a Mulher 2 e, agora, nas áreas limítrofes, afastadas, longe do olhar alheio, para este casal. Há uma sombra que parece ameaçar o estado do idílio apresentado: a própria condição do isolamento, os sinais doentios da natureza.

Aqui, o tempo diegético parece se referir a um período maior em que o casal teria se encontrado, do qual tomamos as cenas referidas como representativas da natureza de experiência que eles teriam vivenciado naquela época. São filmadas, no entanto, em cada momento, como se únicos, singulativos ${ }^{33}$. A cena do banho foi um instante específico, único. Pelo tratamento plástico dado aos enquadramentos que priorizam a natureza - ( num segundo movimento, o casal desaparece de cena, como veremos) - o tempo dado à duração dos planos, contemplativos, a música escolhida para orquestrar e comentar as cenas - L'après - midi dún faune, Debussy, - a ambientação, o casal a sós, isolado no meio da paisagem onde predominam o vazio e o silêncio, as imagens das ruínas e dos parasitos, a natureza descuidada, anti-estética e o casal ilhado, visto ao longe, diminuto sob a imensidão do céu, atribui-se uma atmosfera de distância, do longínquo, do visto ao longe no sentido espacial e que, aqui, adquire também um sentido temporal, uma atmosfera de coisa ida, acontecida, perdida - distância no tempo e não no espaço, - um “lá atrás”. O quadro torna-se emblemático, simbólico. O casal a sós na natureza, no campo vazio, transforma-se em uma imagem $^{34}$, um signo poético, em símbolo. O realismo lírico adquire nuance do onírico. Como imagens de um sonho. Também condensam um período de tempo. Referem-se a uma freqüência daquele tipo de ocorrência no tempo. Mas, como únicos, como singulativas em si,

\footnotetext{
${ }^{33}$ Narrador intra-diegético - Homem 1 - Caminhada Ver Ge. Genette

${ }^{34} \mathrm{Em}$ passagem recente no Brasil, Régis Michel formula a idéia do bloco de carne ao se referir às personagens de Godard, em particular, no caso, no filme Pierrot Lê Fou (1966). Mas isso pode se referir também a A Bout de Souffle (1960): personagens como monolitos, impenetráveis, destituídos de psicologia e que se transformam em designações de idéias, como freqüente no cinema moderno.
} 
podendo estar presente no sincrônico do filme, e não apenas no diacrônico, são, como temos visto em abundância no filme, seqüências pseudo-iterativas ${ }^{35}$.

\section{1.a. O segundo movimento}

Como já vimos ${ }^{36}$, este é o bloco em que as estruturas de primeiro e segundo grau se interagem, os dois tempos, presente e passado, ou presente e futuro, correm em paralelo, simultaneamente. Na situação do presente, no barco, ou do futuro, considerando o passado como o presente, como lembramos, o Homem 1 observa a água do mar, já bastante avançada, penetrando pela fresta aberta na madeira do barco que, aos poucos, também se deteriora. $\mathrm{Na}$ água que invade, a câmera detalha, através de seus olhos - a câmera subjetiva -, os dois gravetos jogados, balançado ao movimento da água e do barco, à deriva. Vemos, a seguir, lembremos, - os três à distância, no barco, e observamos que eles se aproximam, a Mulher 2 do Homem 1, a Mulher 1 achegando-se mais perto dos dois, o grupo ficando assim mais próximo, coeso, como num instinto (grupal), inconsciente, de auto-defesa contra um destino que se apresenta, aos poucos, como inexorável.

Por um outro lado, como são vistos à distância, poderia se tratar simplesmente de uma aproximação das duas mulheres junto ao Homem 1 para melhor lhe ouvir sua história. O que nos coloca, uma vez mais, o duplo sentido que a montagem acaba por estabelecer na relação entre os planos e, no caso, entre as personagens: um da ordem do drama, outro do prosaico, do trivial $^{37}$.

Logo após esse pequeno entrecho do tempo zero da narrativa, voltamos ao passado e revemos, como se colocando em andamento um mau pressentimento, de certo modo, já anunciado na primeira parte e acrescido do sentimento de uma premência com a qual termina

\footnotetext{
${ }^{35}$ Paralipse: (...) "gênero de elipse lateral(...) aí, a narrativa não salta, como na elipse, por cima de um momento, passa ao lado de um dado. Como a elipse temporal, a paralipse presta-se, evidentemente, muito bem, ao preenchimento retrospectivo. Ver Gerard Genette,, O Discurso da Narrativa, ed. Assírio Bacellar p. 109 ${ }^{36}$ Elipse implícita, "aquela cuja presença não está declarada no texto, e que o leitor pode inferir apenas de alguma lacuna cronológica ou de soluções de continuidade narrativa”. Idem, Genette, p. 108.

${ }^{37}$ Tempos mortos.
} 
o segmento imediatamente anterior - (os três aproximando-se no barco) - os mesmos lugares por onde passou o casal, agora, vazio. Na praia, apenas as pegadas; na relva ao redor do lago, não mais os sapatos e as meias. Os parasitos, as ruínas de construções antigas, todos lá: na mesma ordem em que foram vistos na primeira parte, o casal, porém, dissolvido, eclipsado.

A estratégia da moldura faz-se presente: o plano das pegadas na areia da orla e, no final, das vagas das ondas que vêm dissolver essas pegadas, como apagando seus últimos vestígios, definem o segmento.

Há um novo detalhe: os efeitos da imagem em negativo, com que surgem o parasito sobre o tronco nu da árvore, o coqueiro, o poste de eletricidade. Evidenciam-se no efeito e, no contraste gritado das imagens.

O segundo movimento deste ato funciona como uma negação e dissolução do primeiro, o efeito negativo, o outro lado de uma mesma realidade-identidade. Lá, o casal, unido em sua cumplicidade, integrado numa paisagem que parecia ser o comentário de sua própria solidão. Ao mesmo tempo, podíamos sentir que aquela união não era para sempre. $\mathrm{O}$ saber posterior, o ter já se passado por aquilo, coloca a ciência de um ter já se acabado, numa perspectiva do tudo já escrito, tudo já pré-determinado. Uma visão fatalista e conservadora do mundo.

Agora, neste segundo movimento, o casal não é mais visto, tendo deixado apenas o rastro de sua memória na presença daqueles lugares da natureza que parecem responder, com o silêncio, à efemeridade do humano.

Separados pela interposição do pequeno retorno ao tempo zero da narrativa (a situação dos três no barco), eles se opõem em justaposição, novamente como um hai-kai, tal como elaborado no bloco narrativo da Mulher 1. E se opõem, inclusive no sentido físico da matéria daquelas imagens, já que os planos dos locais que se repetem respondem exatamente à ordem e sucessão de quando na primeira vez, no efeito negativo, como se a mesma imagem duplicada. Ou como, da segunda vez, o registro, a marca no sentido literal, da luz queimando a imagem na película (no caso, nossa mente, a mente do espectador mediada pela das personagens narradoras). 
O dado que atesta a procura por um método consciente de construção do filme com aspirações a precisões e relações de equivalência matemática, reflete-se no detalhe de que, a partir do instante em que os três personagens se aproximam no barco, na estrutura de primeiro grau, emendando neste segmento onde vemos a “duplicação” das imagens da natureza em negativo, e onde, para todos os efeitos e tempo, - (no barco, na narrativa de primeiro grau, no campo vazio e nas ruínas, onde o vento começa novamente a surgir anunciando temporal, na narrativa de segundo grau) -, tudo traz a ameaça de um perigo eminente - encontramo-nos exatamente no meio do filme, entre 00:59:15 (imagem dos três náufragos no barco, se aproximando, e dissolvendo-se, novamente na imagem do mar para que se faça o recuo no tempo) e 01:01:15 (imagem do coqueiro seguido da do poste de eletricidade em negativo) como se, no centro de sua estrutura geral, encontrássemos o âmago da estrutura primordial da matéria constitutiva de sua imagem, a marca da luz queimando as linhas divisórias dos contornos das coisas do mundo, deixados impressos e fixados no celulóide e, metaforicamente, na mente, em nossa memória.

Ao mesmo tempo em que elabora os sentidos para as múltiplas narrativas que se desdobram no filme, trabalha-se, igualmente, com o processo de decomposição fisiológica da unidade de tempo até o elemento primordial, mínimo possível, no instante fixado pela queima da imagem no suporte. A imagem em negativo, sendo mais real do que aquela em positivo, mais verdadeira em sua aparência de matéria e não de aparência ilusionista, é, no entanto, a que tende ao abstrato. Um abstrato, não obstante, que grita, na força do seu alto-contraste depurado, como uma aberração expressiva, gritada e posta em evidência de sua legítima natureza: o efeito negativo nos revela a alma daqueles objetos, daquela paisagem, sinistra e doentia (o recorte do parasito grudado, o coqueiro solitário, a rudeza áspera do poste atulhado dos isoladores). Esta sinalização explícita ao comparativo entre o olho, a mente e, agora, a textura básica da matéria constitutiva da imagem (a luz) - já evocada na figura da eletricidade(poste) e no próprio cinema, presente como personagem no Bloco da Mulher 2 (o Homem 2) - prepara a explicitação de um outro método de construção que se anuncia, onde a forma, o movimento e o corpo, hiperbolizados no seu tempo interno, transformam-se em matéria no espaço (do temporal vamos ao espacial) e o humano corpóreo, carnal, transformase em monolito simbólico, em desenho e estilo. O desenho, a forma, destaca-se da narrativa e passa a ser ele próprio motivo da atenção em si, suspendendo e pulverizando o fluxo diegético cronológico, dissipando-o através de formas, impressões de momentos intensificados, 
sensorialmente, na memória (como tem sido, aliás, todo o proceder unificador nos múltiplos estilos e métodos de representação presentes no filme).

Em toda esta primeira parte, tivemos a apresentação de um estado de coisas, de algo que alude a um período de tempo havido: um casal de amantes e, num segundo momento, a dissipação do casal (apenas a natureza permanece). Uma síntese de uma condição.

Inicia-se, agora, o segundo núcleo do filme, o desenvolvimento da narrativa.

\subsection{Desenvolvendo a narrativa}

Evocação de um lugar, que expressa uma condição de vida da qual se deseja fugir (no final da história da Mulher 1, as cenas do vilarejo) - e no início da história da Mulher 2 (as cenas do comércio de peixes na orla, e do vilarejo ao lado), no caso, visto como ambientação de onde a personagem vive; evocação de uma condição de vida expressa na configuração da imagem de uma personagem (marido pianista, Homem 2) evocada, no plano mental, pela personagem narradora; evocação de uma situação-circunstância de vida (condição), no encontro entre os amantes, agora no início da história do Homem 1. Colocado num gráfico, teríamos:

\begin{tabular}{|l|l|l|}
\hline BLOCO MULHER 1 & BLOCO MULHER 2 & BLOCO HOMEM 1 \\
\hline Início: ação/ruptura - & Início: evocação lugarejo & Início: evocação situação \\
caminhadapartida Mulher 1 & Final: evocação situação \\
Final: evocação lugarejo & $\begin{array}{l}\text { condição ritual (encontros } \\
\text { ocultos entre os amantes) }\end{array}$ \\
& $\begin{array}{l}\text { partida (porta e janela } \\
\text { fechadas) }\end{array}$ & $\begin{array}{l}\text { Final: partida no trem - } \\
\text { ação/ruptura }\end{array}$ \\
\hline
\end{tabular}

As simetrias se estabelecem e se respondem, a natureza de estilo do final de um bloco anunciando o início do seguinte, o final fechando-se numa correspondência com o início em equivalência de tema e forma: partida -evocação lugar (condição) / evocação lugar - condição - partida/ evocação do lugar e tempo (condição) - partida). 
Terminada a oposição estrutural entre a evocação do período de tempo em que o casal estaria se encontrando às escondidas $\mathrm{X}$ os maus presságios da natureza através dos sinais emitidos pelos lugares agora vazios dos amantes, - é como se víssemos se definir o início do desenvolvimento de uma ação, de um momento singulativo, de uma narrativa onde o foco passa a ser o Homem 1 que - como com as outras duas personagens femininas, cada qual no episódio que lhe corresponde - passa a ser seguido em sua caminhada.

Como nos outros dois blocos, iniciamos também com o casal parado à soleira de uma porta. Como no Bloco da Mulher 1, a câmera não ultrapassa a soleira, não revela o rosto, no caso, da outra: é pelos detalhes dos movimentos dos seus pés e mãos (aqui, no caso, lábios do Homem 1 que se inclinam para beijar as mãos da mulher, supostamente, sua amante) que temos a apreensão do conjunto da ação, permanecendo portanto, esse todo do conjunto, um tanto difuso, incompleto.

Pelos movimentos indecisos dos pés do Homem 1 que, sobre o limpador de sapatos na soleira da porta, ao rés do chão, dirigem-se ora para um lado e ora para o outro, - entre chamar novamente pela mulher (que se retirou porta adentro) ou partir, - percebemos sua hesitação.

A decupagem pelos detalhes, por partes do corpo, fazem com que os blocos da Mulher 1 e do Homem 1 - colocados como primeira e terceira estrutura de segundo grau ao longo da diacronia do filme - espelhem-se como os dois lados de uma mesma imagem refletida em um espelho e onde a estrutura do meio, a segunda, da Mulher 2, mais descritiva da perspectiva de um narrador extra-diegético na terceira pessoa, onisciente, que admite, como vimos, a revelação do contra- campo e do antagonista, funcione como eixo balizador, como fio norteador de centro, o núcleo de base de uma situação refletida e bipartida em dois polos. É, aliás,como vimos, o episódio de característica e tratamento mais realista do que os outros dois e que, em um cinema de tradição, de gênero, aquele que mais chega a se constituir enquanto narração isenta de ruídos e mediações. 


\subsubsection{Caminhada do Homem 1}

Na caminhada do Homem 1, dilata-se o tempo e, através dela, desfilam imagens dos lugares por que passa e da natureza, novamente. O vento se faz mais forte.

O plano de abertura da seqüência nos traz a angulação com a câmera no nível do chão, o enquadramento fora de prumo, em desequilíbrio, deixando à paisagem a sensação do desequilíbrio e do irregular, do informal.

Um pedaço de barranco à esquerda e uma cancela aberta, em contra-luz, distribuem os pesos nas laterais do quadro. O campo do lado direito é ocupado pela parte maior da cancela, o cercado de madeira. Quase no centro, próximo ao vazado deixado pela sua abertura, duas árvores, juntas, aglomeradas, uma que se destaca à frente. $\mathrm{O}$ enquadramento em desequilíbrio, com a linha de base inclinada para a direita do quadro. Através do vazado deixado pela cancela aberta, na linha do horizonte que então se configura e se emenda no céu que se descortina, surge a figura do Homem 1. De terno e chapéu, à semelhança de uma figura vinda da cidade, recortada no contra-luz, vem na direção da câmera, os passos largos, os braços estendidos, ligeiramente afastados do corpo, caminha até o primeiro plano e cruza o quadro, suas pernas atravessando, cruzando por cima da câmera que ainda permanece por um tempo na paisagem, agora, vazia.

Seu andar é duro, a postura ereta, distanciada.

No contra-luz, a figura humana adquire a consistência de um recorte, de uma sombra: o chapéu, o terno, como um signo, um corpo sem psicologia, que se justapõe à paisagem semi-rural, campestre, prosaica, e avança na direção da câmera. Uma coisa que não é daquele lugar. E que passando, a passos largos, sobre a câmera, acaba por denunciar sua presença.

Há uma confluência entre dois estilos: o ângulo inclinado, que geram a instabilidade, o contra-luz, a presença da paisagem, da natureza, que já ganha corpo nesse bloco narrativo, a ambigüidade gerada pela figura de terno e chapéu, e os ecos de um tema romântico do qual estamos vindo ( o casal a sós, na natureza ) remete a um certo expressionismo, para usarmos novamente a alusão ao cinema alemão do período - o “expressionismo alemão" que, ao mesmo tempo, aqui, pelo “distanciamento” do andar da personagem (andar duro, hierático, os braços levemente afastados do corpo) e a denúncia da presença da câmera, é desmontado. A fruição para este plano, passa a ser diferente do envolvimento psicológico necessário ao desenvolvimento que estávamos presenciando neste bloco, até o momento: o corpo destaca- 
se, ganha evidência enquanto figura, enquanto recorte e, por alguns segundos - (que podem durar) - a narrativa se dilui, se esgarça para que contemplemos apenas a figura: monolito, bloco de carne e não personagem.

A este plano de abertura de seqüência, que é longo, um plano-seqüência, que sai do drama para nos lançar, por um momento, ao plano da idéia, segue-se outro onde a montagem se opera ao nível sincrônico, vertical, no interior de um mesmo campo de visão. Para se expressar a idéia de um simultaneísmo, radicaliza-se no uso das sobreposições: na tela, vemos, sobrepostos, plano dos pés do Homem 1, que caminham, e planos dos lugares pelos quais ele estaria a passar: um determinado alpendre de uma fazenda, uma cerca vista em detalhe, suas barras de madeira em paralelo, detalhes da parte de cima do que poderia ser o mesmo alpendre já visto da perspectiva do caminhante, aqui, de seu interior, do ponto de vista de quem está no lado interno da varanda. São planos também em movimento de câmera. A imagem persiste por um certo tempo: os pés que caminham e, simultaneamente, os lugares por que passa (ou que passam por ele).

Se observarmos, está a se operar aqui, a junção dos dois métodos utilizados nas “caminhadas” da Mulher 1 e Mulher 2: a preferência por uma radicalização do uso da câmera subjetiva da personagem, na Mulher 1, e por uma outra de acompanhamento da personagem, a partir de uma perspectiva exterior, objetiva direta, de um narrador extradiegético, ainda que impregnado das mediações subjetivas de suas personagens. A imagem mostra também a antiga intenção de, ao se mostrar algo, mostrar, antes, a impressão subjetiva dos múltiplos estímulos do real na mente de quem observa. Neste sentido, esta primeira parte da “caminhada do Homem I" é similar à “caminhada da Mulher I" (mostrar a impressão subjetiva da caminhada, ao invés de se ilustrar, objetivamente, a ação física da caminhada).

O caminhante: cujos pés parecem conduzir e não a mente, para quem a paisagem em volta se descortina como manchas que se sobrepõem, de formas fugidias - alpendres, varanda, cercas de madeira - mas todos os lugares, como no filme, no geral, vazios de pessoas, um lugar onde as pessoas sumiram.

Ao mesmo tempo, o caminhante, tão fechado, absorvido, que não vê: a realidade é esses detalhes imprecisos que passam por ele. 
Imagens fugidias que se sobrepõem aos pés caminhantes, pés que parecem caminhar indefinidamente, sem sair do lugar.

Dois plongées acentuados, quase verticais, do Homem 1 caminhando, agora por uma estrada de terra - o primeiro deles, no sentido horário, o segundo, em sentido anti-horário ${ }^{38}$ compõem, novamente, uma moldura que delineia um suceder de planos dos pés do Homem 1 que caminha (em plongées verticais, travellings de acompanhamento laterais, de avanço, de recuo) que se alternam com planos da vegetação sendo, agora, açoitada pelo vento: dois coqueiros, fustigados pelo vento, um capinzal na encosta do morro e, sinistra, uma súbita revoada de urubus.

Enchendo todo o quadro, do capinzal, do mato na encosta, as folhas se movimentam, crispadas, parecendo executar passos de dança no compasso das notas musicais que comentam a seqüência. Notamos a nitidez do tremular das folhagens pelo vento, o balançar que se assemelha a sinais emitidos por ela. Num outro plano, é a câmera (e não a natureza) quem se movimenta em panorâmicas em chicote, borrando a imagem, como se ela, o olhar humano, é quem quisesse se sobrepor aos movimentos provocados pela ventania que quer dissolver, varrer, anular. Mas depois, a câmera (o olhar humano) tende a se estabilizar novamente, deixando que as folhagens, que ocupam todo o quadro, fale por si própria, nos movimentos suaves de oscilação pelo vento, crispados às vezes, reforçando o mau presságio dos urubus surgidos, subitamente, em revoada, no campo.

Há, portanto, o processo de humanização da natureza. Ma há, também, na interferência da câmera ao querer borrá-la, um distanciamento, a afirmação de um outro sujeito-narrador, de fora, - o narrador extra-diegético - que se posiciona, que denuncia sua presença e transportar o fruir, novamente, para o plano da idéia, idéia de alguém que está a pensar por detrás daquilo que mostra.

E, há, através da insistência nos detalhes dos pés que caminham, sem mostrar agora, seu corpo, - os pés são quem designam o homem - a idéia de algo que se faz automaticamente, mecanicamente. Pela ausência do rosto e do corpo do Homem 1 em campo,

\footnotetext{
${ }^{38}$ Ver classificação sistema de classificações proposta por Gerard Genette em “O Discurso da Narrativa”.
} 
podemos sentir um olhar alheio ao mundo em volta, uma consciência tão imersa em si mesmo, que apenas prossegue, como um bloco, um monolito, fechado. Um corpo sem alma. São os pés que o levam. Não é ele quem se leva. Uma “des- subjetivação” do sujeito.

O plongée vertical do Homem 1 na estrada - (à semelhança dos da Mulher 1 - a câmera da altura do poste - e da Mulher 2, vista abaixo, com a sombra do urubu passando pelo chão de terra) - anuncia o final desta primeira parte do segundo da caminhada do Homem 1 : quatro planos, curtos, de pequena árvore numa encosta: três, com a árvore inclinada para a direita do quadro; uma, para a esquerda. O vento que fustiga.

\subsubsection{Retorno ao narrativo-descritivo - uma personagem misteriosa}

A perspectiva frontal é retomada: o Homem 1 surge em quadro, no plano médio para cima, a gravata destacando-se no fundo da camisa clara sob o paletó. Está, desta vez, sem o chapéu, que traz em suas mãos que levanta, para tentar acender o cigarro. Não consegue. O vento o impede.

Um corte em continuidade retoma-o na mesma perspectiva: ele avança novamente, em direção à câmera, até chegar ao Primeiro Plano, em contra-plongée: tenta, mais uma vez, acender o cigarro. No gesto de sacudir o palito de fósforo, seu rosto, casualmente, volta-se à sua direita ( à esquerda do quadro ). E nota algo.

A ausência do chapéu na cabeça, os gestos mais “naturais”, as tentativas banais de acender o cigarro, devolvem à figura, ao corpo sem alma da seqüência anterior, seu lado de humanidade.

Seus passos o guiaram, sem que o soubesse, até ali. Súbito e inesperadamente, pode se dar "por achado".

A interferência do narrador, mais uma vez, se faz sentir: a câmera (como já fizera com as outras duas mulheres, Mulher 1 e Mulher 2, em seqüências que apontavam para mudanças importantes no modo de se elaborar o tempo na narrativa), - de forma independente, faz a 
panorâmica à esquerda, desta vez, porém, seguindo a direção do olhar do Homem 1 - e não abandonando a personagem de vez - e, cortando-o de campo, volta-se para o local que ele observara: um muro, com flores embaixo. O Homem 1 torna a entra em campo e dirige-se até o portão de ferro que guarda a entrada de um cemitério.

No céu, nuvens pesadas anunciam chuva.

O Homem 1, parado por um instante, diante do portão.

A câmera, independente, como um personagem, avança na sua direção, passa por ele e, de modo difuso, perdendo o foco de visão, entra no cemitério: arbustos mal cuidados espalham-se e, ao fundo, a figura de um estranho, sentado, ao lado do túmulo.

Sucessivas fusões fazem crescer, por aproximações aos nossos olhos, a figura desse homem, magro, jovem, de terno, sentado, inclinado ao lado do túmulo, até o detalhe de um anel que manuseia entre seus dedos.

Este detalhe, foco de atenção, pode ser um ponto de vista do Homem 1, pois logo, o vemos, novamente, ainda parado, de costas, no mesmo lugar, no portão de ferro, olhando na direção do estranho que se encontra ao lado do túmulo.

Momento em que a câmera se confunde, mistura-se aos olhos da personagem, ela, inclusive, se recuperamos a grande estrutura por trás, a narradora intra-diegética deste bloco.

O segundo marido nesta história, o marido da mulher com quem acabara de estar o Homem 1, encontra-se sentado, agachado, ao lado de um túmulo, túmulo para o qual o Homem 1 se dirigia.

O encontro é casual.

Na caminhada até o túmulo, o Homem 1 colhe um flor, pequena, silvestre; e a câmera segue o movimento, acompanhando a flor oscilando na mão do Homem que a carrega, assim como, em outro tempo, em outro lugar, lá atrás, também víramos a câmera oscilar, acompanhando o balanço suave do cesto com o peixe morto e os legumes sendo carregado pela Mulher 2.

No filme, os gestos, os movimentos, os acontecimentos, através das três histórias, dos três episódios, repetem-se, a cada momento, de forma diferente, em um novo andamento que vai se alterando, aos poucos, como numa mesma evolução em círculos, os mesmos movimentos, num ritual. Como se cada personagem refizesse o percurso já feito pelo outro em um outro tempo e lugar. 
Há visível rancor nos olhos do homem magro. O rosto de traços angulosos, aquilino, as sobrancelhas finas, os cabelos engomados, penteados à risca, como uma placa colada na precisão, os fios todos domesticados, contidos, ordenados. Por outro lado, demonstra ser alguém de certa estirpe.

Há um sapo próximo a eles, ao lado de onde se posicionaram os pés do Homem 1.

O Homem 1 chuta o sapo, vira-se, para partir.

Mas a câmera detalha o gesto da mão do homem magro, segurando-o: puxa-o, retem, pela aba do paletó.

O gesto é físico e enfático, faz o Homem 1 ter que se voltar.

Insolente, juvenil em seu ar pedante, provocativo, com os dedos em um gesto típico, o homem magro lhe acena como quem pede fogo para cigarro.

Nos gestos lentos, estudados, o Homem 1 leva as mãos ao bolso, (a câmera desce, acompanhando o movimento), e o vemos pegar a carteira de cigarros de onde retira um, batendo-o, e o levando à boca, as mãos procuram a caixa de fósforo para acendê-lo.

Quando se inclina para oferecer o fogo ao homem magro, atendendo-lhe o pedido, o que o espera é o gesto provocativo, de afronta, petulante, artificioso, de quem lhe ostenta uma piteira vazia. Os olhos do homem magro fixos nele para ver sua reação, num estudo de quem provoca, abertos.

O Homem 1 pára, o gesto interrompido sem entender, o homem magro olhando para ele, um sorriso desafiante se desenha, mas o Homem 1 se levanta, enraivecido, atira o cigarro ao chão. Fica um tempo olhando para ele, em tom de desafio.

O homem magro, os cabelos extremamente ajeitados, lustrosos e engomados, a risca quase ao meio, o cuidado meticuloso no penteado, na indumentária, aos poucos, então, levanta o seu rosto, ostentando a expressão de ódio, de rancor e desprezo, uma exibição desafiante, mas com ares de afetado, alguma coisa de calculado, de teatral na expressão. A única fala do filme, único momento em que vemos (ouvimos) o que uma personagem diz: "Você vem da casa da mulher que não é sua..." - aponta o dedo para o túmulo - "suppondo que ella seja minha como está foi sua" - aproxima-se irado, incontido: - "e se eu lhe disser que ella é morphética?”. 
A fala nos dá conta, num golpe de síntese, da rede de relações por trás daquelas personagens, revelando, no instantâneo, os elementos do drama em jogo: o acaso, a ironia da lógica com que os fatos se sucedem e os destinos das personagens se entrecruzam.

Curiosamente, nesta cena, o que acabamos de ver é a reconstituição de um pequeno entrecho melodramático, com recursos do campo e contra-campo na decupagem que ilustra o confronto entre os dois homens, inclusive, na alusão a uma intriga de "ciranda" de maridos e esposas traídos.

Limite, neste momento, caminha para um cinema narrativo dramático.

\subsection{3.a. Uma composição se insinua - uma narrativa (oculta) possível}

Já vimos a reação que a frase provoca no tempo futuro do filme, na estrutura de primeiro grau: no barco, imediatamente após, as duas mulheres, como se movidas por um instinto, afastam-se do Homem 1. E ele próprio esfrega o lenço na boca, numa expressão de nojo.

O que nos falta observar é o plano que, imediatamente sucede o momento, trazendo de volta o passado, se consideramos a situação do barco como o presente:

Vemos os dois homens, jovens ainda, - se pensamos bem, - parados, recortados em contra-plongée contra o céu, o vazio do espaço em volta.

Os dois juntos, parados, na composição, parecem se refletir como os dois lados de um mesmo ser através do espelho.De costas, alto, a coluna um pouco envergada, o homem magro, o marido da "outra”, e, em segundo plano, a cabeça igualmente inclinada para baixo, dandolhe a expressão de quem reflete longamente sobre algo, medindo algum peso, da mesma forma o outro, também a cabeça inclinada para baixo, reflexivo.

A perspectiva do quadro favorece a proximidade de distância entre eles: estão próximos, contra o céu, e parecem, por um instante, flagrado, pensativos.

Como se medissem algo.

O homem magro é quem toma a decisão, leva o chapéu à cabeça, coloca-o e sai de quadro pela direita, afastando-se. 
O Homem 1 permanece ainda em quadro, leva um tempo para reagir, e voltar-se na direção de onde partiu o "outro".

Como se vê, estamos iniciando um novo movimento na curva dramática e narrativa do filme.

Uma corrida exasperada, louca, que o Homem 1 empreende, através de uma natureza agora estática, as folhas do capinzal, altas, paralisadas, indiferentes e afirmativas, como se numa inversão entre o positivo e o negativo.

O Homem 1 corre, desesperado, em convulsão interna expressa nos movimentos grandiloqüentes, de correr, de surgir, em contra-plongée, na linha divisória do horizonte, as pontas selvagens do matagal, do capinzal, eriçadas, aparecendo irregulares no contra-luz, o vazio do céu predominando.

Ele grita pelo nome do homem magro, de pontos elevados, escalando um barranco, atravessando alagados, lama, o capinzal estático. Todo o movimento é dele e sobre ele, gritando o nome do homem magro, chamando-o, a câmera avançando sucessivas vezes sobre seu primeiro plano, no contra-plongée, a mão em círculo ao redor da boca. Ele grita, a câmera avança sucessivas vezes sobre sua boca que grita, como avançou, em episódio passado, sobre o orifício da boca do chafariz de onde jorrava água.

A câmera, em panorâmicas tão velozes que borram a imagem, transmitindo a sensação de um aceleramento, - os movimentos em chicote - pontua a seqüência, abrindo-a, intervindo, criando o efeito de dissolução, de apagar da imagem num borrão, em seu final.

Toda esta seqüência que deseja explodir, colocar a personagem em situação limite para que se justifiquem as manifestações estéticas de desejo de ruptura soam grandiloqüentes e desproporcionais se consideramos que a causa do desespero do Homem 1 tenha sido ter sabido da doença da mulher pela qual se sentia apaixonado.

Ele corre, desesperadamente, atrás do outro para saber de mais notícias, de mais detalhes de tudo aquilo? É um desespero afetado, onde a gestualização soa algo como teatral, que quer se mostrar de forma explosiva, exasperada.

Logo no início da corrida, temos o plano onde se vê o Homem 1 que corre atrás, ao longe de uma estrada, em cujo final, na linha de fuga, avista-se a figura do homem magro - e sinistro - que se afasta. 
A distância longínqua entre os dois, apesar de tudo, não justifica a intensidade do grito que o Homem 1 empreende - as mãos ao redor da boca, com a qual ele grita com todas as suas forças. Há um desespero cuja intensidade no desejo de ruptura formal é desproporcional aos arranjos oferecidos pelo enredo.

Então, pensamos nas imagens do encontro, na afetação estampada no rosto esquelético, avaro, cheio de ressentimentos do homem magro, misterioso, no início. Faz a provocação na forma de um desafio, há lampejo de uma crueldade juvenil em seus olhos no momento em que dispara o segredo de sua, na verdade, esposa: a mulher é morphética.

Ferido no orgulho, ressentido, o homem magro agride, agredindo a própria mulher por quem, no fundo, talvez, agora, só sinta desprezo. O plano dos dois próximos, juntos e pensativos, recortados contra o céu, surpreendidos pelo impacto da revelação proferida, reflexivos fundamentalmente, pode surpreender um flagrante de cumplicidade momentânea.

Depois, o homem magro se retira, o Homem 1 leva ainda um tempo para se recompor e correr atrás, não da mulher que julgara amar e cuja menção da doença o afasta, mas do outro homem, o magro, agora, seu cúmplice nesse melodrama familiar.

O desespero aqui, o ressentimento do "outro", é de um para com o outro, e não na direção da mulher. Era preciso que eles se conhecessem, como já indicava a cena do cemitério no seu início, no primeiro olhar que se trocam, mas seria preciso que se conhecem mais profundamente, ou sentissem, em algum momento, o ressentimento de uma amizade traída, uma confiança desfeita.

O Homem 1 quer ainda alcançar o homem magro, não pelo que ele lhe dissera sobre sua mulher com o claro propósito de feri-lo, mas para desfazer o mau-entendido possível, a possibilidade de um erro a ser corrigido, uma falta a ser reparada, uma distância a ser reaproximada. É por ele mesmo, são por eles mesmos.

A afetação da dor, do ressentimento, demonstrada pelo homem magro, no orgulho que se exibe ferido, na atitude infantil da provocação agressiva através da piteira vazia, faz subentender um ressentimento para com o outro, antes do que para com ela. São sentimentos contraditórios de um exibicionismo narciso, que se denuncia no modo travestido de ser e se trajar. Seus gestos, sua postura, o excessivo ajeitamento de tudo nos mínimos detalhes, a risca quase no meio dos cabelos penteados, rigidamente desenhados, firmes e assentados, os lábios que se insinuam nas palavras, manifestando o exibicionismo da dor raivosa do auto-ferido, uma crueldade manifesta, o prazer no sofrimento e na dor do algoz e da vítima que se 
espelham nos olhos que afrontam de modo pedante, sibilante, blasé: o misógino, o olhar que não se compromete a não ser consigo mesmo, o olhar de fora, o olhar distanciado, o olhar de um dândi.

O amor homossexual ferido. A misoginia se acentua, quando mais, na procura desesperada pelo outro, o Homem 1 depara-se com uma mulher, que tem o olhar levemente ensandecido, o sorriso malicioso que se insinua coquete, mordendo "pecaminosamente” uma maçã.

Uma mulher do cais, anônima como os demais personagens, e que lhe aparece do nada, ali, à sua frente. No seu desespero caótico, tenta descrever o homem para ela, com os gestos das mãos, os lábios que pronunciam acentuadas as palavras, o olhar de quem quer se fazer entender - "um homem magro, alto...” - mas é inútil, pois ela lhe parece alheia, o enquadramento fixa seus olhos distantes, - ela morde o fruto, alheia - e só lhe resta empurrá la de lado e se ir. "Morphética”. A lepra é a doença que traz o medo do contágio; no filme, a mulher traz a lepra em seu corpo. A mulher, de quem fora amante, a mulher, prostituta no cais, portadora do mal, e que come o fruto proibido. A simbologia tende ao elementar.

O descompasso entre o exagero estético na forma que se adota na seqüência da corrida do Homem 1 e a motivação dramática do enredo manifesta-se, de modo explícito, no plano que é ponto-auge que marca, por.exemplo, a divisão entre o segmento em que vemos o Homem 1 correr, gritar pelo nome do homem magro e os borrões da câmera na paisagem de modo a estabelecer a idéia rítmica do crescendo, do aceleramento do tempo, transformar no abstrato o ilustrativo, em rítmico o que é figurativo, - e o que lhe segue, a chegada do Homem 1 no cais e seu encontro com a mulher alheia: um plongée vertical, radical, a música (escolhida para o filme) - grandiloqüente, A Sagração da Primavera, de Strawinsky, toda a grandiosidade da forma que contrasta com o prosaico no conteúdo da imagem: o Homem 1, finalmente parado, em pé, se inclina para o trivial gesto de amarrar os cadarços do sapato.

A forma se descola da história, adianta-se e vem a primeiro plano.

Limite, nesta terceira das estruturas de segundo grau, em seu segundo grande ato, expõe, em sua fatura, os dois métodos: o da continuidade temporal de seguir a personagem até desembocar no arremedo de um cinema de gênero entre o expressionismo e o melodrama (o “expressionismo caboclo" dos letreiros ${ }^{39}$ ) um dos métodos que vinha desenvolvendo desde o

\footnotetext{
${ }^{39}$ Octávio de Farias já se referia a isso.
} 
primeiro dos três recuos no tempo: o cinema como se fosse uma partitura musical, inspirada em regras matemáticas de construções rítmicas na ordenação de suas frases temporais $e$ imagéticas à equivalência das frases musicais. Aos poucos, tende a dissolver o figurativo no abstrato, que se revela através de estruturas matemáticas de construção, onde as categorias do espacial e do temporal se misturam.

É através de um interior que não identificamos direito, mas provavelmente da perspectiva de uma cabana de pescador qualquer pois, pela moldura de uma janela, vê-se um cercado de arame atrás do qual a figura do Homem 1 se achega e, por outra, o contra-luz de uma choupana de pescadores à beira-mar. Lá de fora, o Homem 1 chama por alguém, descreve, pelos gestos, o homem "alto e magro", por quem procura.

Ele caminha, até rente à cerca e, apoiando-se nela, por fim, se deixa cair: a câmera faz o movimento já aqui mencionado, o segundo ponto ápice do filme, no auge da curvatura, (na estrutura geral do filme, eqüidistante ao plano dos olhos aterrados da Mulher 2 debruçada, do alto, à beira do penhasco): do sapato do Homem 1, caído na lama, ascende-se até o alto, no topo da cúpula do céu, passando pelo cercado de arame, a faixa litorânea, a claridade do céu, até o alto, para regressar à terra novamente, e terminar por enquadrar, desta vez, sua mão, igualmente caída, enterrada na areia.

Em fusão, a mão vai se evanescendo, cedendo à imagem de degraus de uma escada, na verdade, as laterais em desníveis de um túmulo.

\subsection{3.b. A caminho do epílogo - uma outra narrativa paralela possível}

A água da chuva, anunciada pelo vento na paisagem, pelas nuvens fechadas no céu (no momento em que o Homem 1 chegara ao portão do cemitério), finalmente cai, lavando as pedras do túmulo.

Notas musicais sugerem atmosfera de leveza, de amanhecer. Nas imagens, é como se a chuva viesse para lavar as almas, expurgar os pecados. Há três planos das nuvens nos céus, referência às chuvas, e às já mencionadas imagens do cruzeiro, - de duas cruzes que se fixam em uma - para emoldurar uma pequena seqüência de cenas bucólicas, evocação do que seria a vida tranqüila, diária, de uma aldeia de pescadores: imagens plácidas, com senso de equilíbrio na composição, das redes estendidas, da cabana a pau-a-pique, dos barcos de madeira, com 
seus remos, dois pescadores, vistos à distância, surpreendidos nos seus afazeres de costurar redes.

Pelos movimentos de seus lábios, vemos que falam, mas não ouvimos o que falam. São cenas documentais, filmadas à distância, compondo paisagens de natureza morta, idílicas pela suavidade da luz, pela calmaria local.

Elas subentendem outras seqüências possíveis, que estariam a ocorrer em paralelo, e que estão elididas, mas que, mesmo suprimidas, permanecem, de uma forma alusiva, através da reconstituição de um estado de espírito que, no caso, é sugestionado por um determinado ritmo, calmo, de gradual amanhecer, através das sucessões de ângulos que vão apontando, numa aproximação progressiva, para a presença do humano na praia (a pedra, a orla, a areia, a vegetação, os barcos ao longe, as redes, a cabana, os homens), da natureza de suas imagens (os tons paisagísticos de uma aldeia de pescadores, num amanhecer), da tranqüilidade dos movimentos (o remendar as redes), na trivialidade da idéia de um cotidiano pacato naquela pequena aldeia e que evocam a sensação similar que nos permite compreender um novo outro sentido por trás, uma outra narrativa possível, paralela, que estaria a ocorrer ou teria ocorrido e que não vemos (as paralipses, na classificação de Gerard Genette - ver. (29).

O tom de singeleza, de lirismo quase parnasiano, da seqüência de quadros compondo cenas "típicas", mas ao mesmo tempo, filmadas de modo a que os corpos humanos não ocupem presença ostensiva no espaço - são figuras vistas ao longe, desprotegidas do aparato da encenação teatral, colhidas ao natural, dissolvidas na paisagem - (os pescadores, em segundo plano, costurando a rede)-, filmadas à luz da manhã, logo após o desabar das águas da chuva que vieram para lavar o túmulo, nos deixam subentender um determinado estado, após todo o crescendo dramático visto - que é o da recuperação, de uma convalescença.

\section{Convalescença do Homem 1.}

E intuímos, que aquele descritivo bucólico, tranqüilo, daquela aldeia, naquele amanhecer, poderia estar a ocultar todo um período - uma narrativa - de convalescença que a personagem do Homem 1 teria passado naquela aldeia, acolhido pelos seus habitantes (lembremos que sua queda dera-se próximo a cabanas à beira-mar).

Uma espécie de Gauguin convalescendo-se nas ilhas dos mares dos trópicos. 


\subsection{3.c. Epílogo - partida}

A intuição da elipse hipotética confirma-se com a afirmação, novamente, dos sapatos do Homem 1 que, após um plano de um cruzeiro contra o céu (alusivo à morte de alguém? Da mulher com a lepra? - ou apenas um cruzeiro, em si?), e de uma bomba de gasolina, filmada somente em sua base, com pés de transeuntes passando, “revigorados”, voltam a caminhar.

Eles ressurgem, firmes, conduzindo nossa personagem, desta vez, a caminho da estação de trem. Ao contrário da Mulher 1, cujas partidas eram aludidas pela imagem da roda do trem girando, num cinema de montagem por elipses, veremos a personagem dirigir-se ao guichê para comprar o bilhete, num cinema que volta a seguir o corpo humano em movimento.

O Homem 1, nesse momento, conduzido pelos sapatos (os planos em detalhe dos pés que caminham), quando mostrado em primeiro plano, o é em contra-plongée ( a câmera recortando sua figura contra o céu ), duro, lacônico, com seu paletó, gravata e chapéu.

Voltou a ser o corpo em estado mineral em movimento. Uma figura de gênero. Uma figura.

Distanciado, despsicologizado.

É curiosa a maneira como aparece a cidade no filme.

É também mais pelo fora de campo do que pelo que vemos em si.

Uma bomba de gasolina, velha, puída, e pés que passam por ela. Descalços, de menino, de senhoras, de botas de soldados, um cachorro. Sente-se a movimentação, os ruídos do dia-a-dia citadino.

Os pés que conduzem as pessoas.

Aqui, finalmente, um pouco, as pessoas. O mundo em movimento.

Mas não são elas o que importa.

O mundo é só ruído, transação de pés impessoais que vão de um lado a outro ao redor da bomba de gasolina. Pés anônimos, sem dono. 
O automóvel (a bomba de gasolina), outro símbolo da modernidade. Mas a bomba é velha e a rua é de terra.

O episódio referente ao Homem 1 evolui da narrativa através das condensações do tempo, da justaposição dos momentos (os encontros do casal no início), para um cinema da continuidade temporal, concentração do tempo diegético (uma parte do dia do encontro entre os dois homens ) escandido ao máximo na duração da experiência de sua interioridade - o cinema da continuidade no tempo interno dos momentos.

Retoma, desta forma, o movimento já iniciado no bloco narrativo de segundo grau que lhe é imediatamente anterior - o Bloco da Mulher 2. Altera, porém, no modo de representação: no bloco da Mulher 2, as personagens eram, de certa forma, psicologizadas: estampada na face da Mulher 2, toda sua decepção, sua amargura. Na do Homem 1, um desacerto entre momentos de interiorização e aqueles em que surge em sua visão distanciada do mundo, de um dândi, até a de um decalque de figura.

A mulher-amante, apesar de não termos seu rosto, - à semelhança do personagem do “outro homem”, no episódio da Mulher 1 - provoca, porém efeito diferente: no primeiro caso, não há vínculos de afetividade, trata-se de relações movidas pelo senso do pragmatismo. No segundo caso, é um amor às escondidas, o que implica na cumplicidade do casal diante do mundo; há o impedimento da doença, o que pode aumentar, em grau, a dimensão da paixão, na medida em que na paixão, o fundamento é na construção da imagem: apaixonamo-nos pela imagem das coisas, não pelas coisas em si. Donde a carga de nostalgia maior que emana deste terceiro bloco: ao se ver momentos de felicidade, sente-se, simultaneamente, a nostalgia por se já tê-los perdidos (seqüência que abre o bloco do Homem 1).

Os chicotes, velozes sobre a natureza, que se repetem, pontuando a seqüência (movimentos “artificiais” da câmera sobre a natureza), do mesmo modo que os avanços da câmera sobre o rosto do Homem gritando ou se contorcendo (igualmente, movimentos artificais, intencionais da câmera), deixam em evidência a intenção de uma idéia transgressiva por trás. Trata-se da expressão de um sentimento de exaspero desconstruído formalmente, pois sua lógica de organização é métrica, matemática, de ritmo. Na representação, temos ainda, a "personagem-monolito" do caminhante transfigurada em idéia e a dissolução da 
imagem da natureza através dos borrões da câmera, recorrendo ao plástico-rítmico-abstrato (a sensação física), ao invés do figurativo- psicológico-literário-cognoscível.

Essa hiperbolização da forma que, por vezes, se adianta à história, já víramos se desenvolver no bloco da Mulher 2 (por exemplo, os próprios avanços sucessivos da câmera sobre a fonte). Ali, porém, ligada a uma projeção psicológica, afetiva da personagem (tudo poderia ser imaginário projetivo dela, narradora intra-diegética em seu episódio e, simultaneamente, da Mulher 1 que rememora tudo, neste caso, mediada pela subjetividade da Mulher 2).

Na seqüência analisada no bloco do Homem 1, trata-se de um desejo de expressão do narrador de fora da ação que se apropria do sentimento interior que a personagem vivencia para expressar uma idéia de transgressão e evasão plásticas referidas à idéia do aprisionamento que pesa sobre ela. A intenção estética se denuncia. E promove o efeito do distanciamento psicológico. Em alguns momentos, leva os momentos ao nível da idéia (idéias de personagens, idéias de situações), em outros ao do sensorial e à da atmosfera, construídos pela freqüência rítmica com que determinados planos se repetem ou se alternam, de acordo com o andamento da escala melódica do conjunto, fazendo subentender enormes seqüências, vidas e outros filmes possíveis que se insinuam nas brechas, nos interstícios, nos interregnos desses momentos, cenas e planos hiperbolizados enquanto forma, que vemos. Tais são as paralipses insinuadas em pelo menos dois momentos aqui vistos.

Esta montagem que tende a se resolver no gráfico-geométrico-aritmético (numa variante da montagem métrica), no plástico-rítmico-visual, no musical, é a que rege o ponto conclusivo do filme como um todo, a seqüência da tempestade.

\subsection{Personagens e estrutura - uma estética burguesa?}

As caracterizações das personagens - à exceção da mulher do cais, que apresenta pontos de aproximação com a Mulher 1 (de vida independente) - definem uma estilização de suas origens sociais: terno, gravata, chapéu, sapatos e meias femininas que remetem ao recato de uma condição que preserva sua intimidade, e que as diferenciam do espaço social onde estão situadas: as proximidades de uma aldeia de pescadores. O que, evidentemente, as aproxima com a caracterização da Mulher 2 (no Bloco 2): também ela vivendo em um meio ao qual não pertence e com um marido do qual, culturalmente, parece muito distante. 
Por outro lado, como vimos, há, na encenação e na forma da montagem, a presença de ruídos: o conjunto revela-se mais fragmentado, com arestas e incongruências, do que o aparente. Passa-se de um cinema de montagem a um cinema de continuísmo e imanência; na encenação de um cinema que flerta com elementos do melodrama (a ciranda de casais, a traição, o orgulho ferido e o ressentimento), em seus pontos fortes, tais sejam, a abertura do primeiro movimento do segundo ato (momento em que o Homem 1 se despede da mulher e inicia sua caminhada, sua caminhada propriamente dita) ou de crescendo dramático, como na corrida do Homem I, expõe-se enquanto forma, através de uma montagem rítmica, baseada em estruturas matemáticas de composição, ou seja, um cinema metalinguístico e formalista.

Temos, portanto, duas estruturas em contradição a se operar: uma mais associada ao cinema da vanguarda estética, e outra ao cinema conservador, narrativo clássico. O que, de certa forma, espelha o caráter de ambigüidade que emana das imagens do filme: lances de modernidade, impregnados de sentimentos do passado. Formalmente avançado, de dramaturgia e sentimentos conservadores.

\section{A SEQUÊNCIA DA TEMPESTADE}

Desde o início, já observávamos momentos em que a forma salientava-se como evidência na construção do filme: a presença da luz cintilante na superfície das águas do mar, a luz clara, mítica, que parece imantar a pele das personagens, os ângulos que favorecem o desenho preciso de formas inscritas na natureza. Nas estruturas narrativas de segundo grau, nos recuos do tempo - no bloco da Mulher 1, a presença em detalhe dos objetos de costura; no bloco da Mulher 2, a insistência da câmera em repetidos avanços de câmera sobre a bica d'água, em torno dos quais se distribuem os demais planos do vilarejo litorâneo; no do Homem 1, os movimentos borrados da câmera em chicote que pontuam, - repetindo-se, entre os planos do Homem 1 correndo, com dificuldades, através do matagal e os avanços de câmera, nas repetidas vezes, sobre o Homem 1 que grita e se contorce. Uma ocupação em se estruturar ritmicamente a seqüência, não no sentido da descrição linear de um evento na lógica da causa-e-efeito, mas através da construção de uma estrutura rítmica elaborada pela repetição de uma unidade mínima de imagem que se intercala, se interpõe, numa determinada freqüência, entre outros planos que giram ao redor .

No caso específico já visto dos movimentos borrados de câmera, em chicote, sobre a natureza, o efeito de um olhar exterior, calculado, de fora, que se sobrepõe à imagem da 
natureza que não vemos, pois borrada, negada, dissolvida, intercalados como estão, prestamse mais a um chamar a atenção para si enquanto ruído provocado, interferência, mais no nível do inteligível no plano da forma sensível, do que no da idéia (literária) do enredo que possa eventualmente se encontrar através daquela forma, enquanto experiência emotiva. As rupturas formais apresentam-se de forma explícita, o que impõe uma comunicação no nível portanto, rítmico, gráfico, se quisermos (a bi-dimensionalidade súbita a que a tela se vê reduzida diante do borrado que nega qualquer ilusionismo), chamando a forma de volta a si mesma, deixando, para segundo plano, o enredo.

Um cinema de música, de formas que se interpõem no tempo, através de uma métrica arbitrariamente determinada.

O que nos exige um fruir diferente daquele onde nos identificamos com um drama, ou uma narrativa com representação ilusionista. Os borrões na imagem, as imagens em negativo, as intercalações de planos que se repetem - onde se sente a presença da técnica - a natureza onde sentimos a ausência do humano (naturezas mortas), onde, por vezes, o próprio elemento humano confunde-se com a natureza morta (os planos onde as figuras humanas surgem diminutas no quadro, como se um dos elementos a mais, entre outros), as personagens que surgem, em momentos, como índices de modelos de representação (o homem de terno, chapéu e gravata, de corte moderno, na estrada de terra) - tudo tende a uma linguagem que busca também uma forma de comunicação e expressão essencialmente pela plástica da imagem e pela estrutura rítmica Tudo se passa no nível do modelo da representação em si, no que se refere à moldura formal de uma janela, aquela que se abre para o mundo.

A tempestade, em si, quando surge, não é de representação naturalista. Não é uma tempestade que, cenicamente, convença enquanto fenômeno natural. É, como vimos freqüente no filme, a representação de uma idéia de tempestade.

Longa, a idéia da seqüência tenta ser transmitida através dos recursos, novamente, da montagem que procura extrair efeitos de progressivo acúmulo de águas que tomam a tela, utilizando-se ora da repetição de movimentos similares, ora do contraste entre linhas de sentidos opostos. É um desenho que se esboça e se configura através de uma articulação rítmica que alterna, tecnicamente, planos do encontro de duas águas do mar com seus movimentos de avanço e refluxo, planos de águas se chocando contra um rochedo e que se repetem na pontuação da seqüência, na medida em que a intensidade cresce; e planos mais fechados dos choques e volteios das ondas que se sobrepõem, em detalhe, nesse encontro das 
duas águas., com closes de ondas que "borram" a tela, dissipando a imagem nos movimentos de turbulência das águas que, pela proximidade com a lente, saem de definição.

Como se vê, o mesmo procedimento que já vinha se delineando no filme de, pela repetição, alternância entre os planos e articulação num crescendo rítmico com movimentos contrários de refluxos, construir, através de uma montagem puramente plástica e rítmica, a idéia do drama a ser apresentado ou, no caso, evocado (como praticado pelo cinema construtivista russo, no período), onde leva-se em conta a duração física dos planos, ordem e critério de intercalação entre eles num sentido sensorial e calcado em combinações numéricas de freqüência e retorno das imagens no tempo.

Em si, o conteúdo interno de cada plano não se refere a uma tempestade propriamente dita, e a cadência um tanto vivaz da música aqui estabelecida para acompanhá-la (Prokofiev) deixa um tanto ambíguo o sentido trágico da tempestade.

A tempestade, no filme, é não exatamente a reconstituição de um fenômeno natural, mas um comentário plástico e musical sobre a idéia desse fenômeno. No filme, sua realização se efetiva de modo a que ela se apresente quase como se uma grande orquestração, uma dança das águas.

O efeito final é de um acúmulo de água que chega, em tom até mesmo alegre, exacerbado em sua duração, parecendo executar, na forma de um sentimento de alívio, de modo quase apoteótico, o final de um drama sem saída. Lavar a alma. O drama do homem, para o qual a terra não oferece perspectivas, expulsando-o de volta ao mar, devolvendo-o ao seu elemento de origem: a água.

Essa ausência de perspectiva é tecida, em parte, com a cumplicidade deste próprio homem. Porque são impedimentos que ele se auto-impõe, na auto-comiseração de um isolamento que não consegue transpor.

Não o consegue por não desejá-lo. Pelos ganhos que obtém no próprio usufruir de seus sentimentos a respeito do impossível. Um masoquismo. Por outro lado, uma espécie do sentimento próximo ao dandismo, ao não comprometimento com o que é transitório, próprio de uma aristocracia ainda incapaz do convívio com a modernidade tal como se apresenta nesse momento: a modernidade do mundo laico. 


\section{UMA HISTÓRIA POSSÍVEL - A AMBIGÜIDADE DA IMAGEM}

No início, havíamos comentado, a respeito da estrutura narrativa de primeiro grau, sobre o plano em que a câmera, gradualmente, passava do plongée (a câmera no nível superior) - até então usada quase integralmente nesta estrutura, - ao contra-plongée (câmera baixa), até chegar à meia-altura, altura dos olhos, do rosto da Mulher 1.

Este plano seria o anúncio de outro similar, mais à frente, após a seqüência da tempestade, que poderia estabelecer a ligação com a frontalidade dos olhos em detalhe, neutros, da Mulher 1, - (do início do filme) - fechando a moldura, juntamente com a imagem da alegoria..

São dois Primeiros Planos da Mulher 1, - a essa altura, já só, no barco, - (o Homem 1 se lançou ao mar, e a Mulher 2 desapareceu, após ser sido empurrada para fora de campo) : no primeiro, ela, no barco, antes da tempestade; no segundo, com os cabelos molhados, sobrevivente, agarrada a uma tábua.

Esses dois planos de rostos da Mulher 1, o primeiro, em enquadramento frontal, os olhos na direção da câmera, a cabeça entre as mãos; o segundo, agarrada à tábua,, em contraplongée, os fios de cabelos lhe caindo sobre o rosto, seus olhos direcionados para baixo, reflexivos: entre eles, a seqüência da tempestade. Os dois planos compõem a moldura para a tempestade.

Este último plano, dela, olhando para baixo, reflexiva, os cabelos molhados cobrindolhe o rosto, é o que emerge - emerge pelo efeito de fusão, gradualmente - surgindo, aos poucos, e se impondo ao plano que lhe antecede: um plongée dela mesma, a Mulher 1, no momento em que emergira da tempestade, no meio da superfície das águas do mar, só, agarrada à tábua.de madeira.

O modo como o rosto surge, lentamente, reflexivo, filmado de baixo para cima, o olhar direcionado para baixo, em tom interiorizado, por trás dos cabelos, é como fosse ela a estar rememorando, a si mesma, como vista há pouco: só, no meio do mar, agarrada a uma tábua. Ela mesma recordando, vendo-se, e tendo visto todo o ocorrido.

A seguir, seu rosto, esse olhar para baixo, os olhos por trás dos cabelos úmidos = reflexivos - começam a desaparecer (por nova fusão) - e, aos poucos, ceder a uma nova imagem que surge, nítida, recortada em fundo preto, - como se fosse uma imagem de seu 
pensamento - e ela se vê, a si mesma, presa, enredada, pelos punhos do homem, por sua vez, presos numa algema.

A imagem da alegoria, que surge (por fusão) - como se fosse seu pensamento - é uma imagem projetada de sua mente. É expressão de seu pensamento. Como eram os detalhes nítidos da imagem do marido roto na mente da Mulher 2, naquela tarde, no alto do penhasco.

Uma imagem mental, expressão de seu interior, de como ela se sente naquele momento.

Aos poucos, novo efeito de fusão, e a vemos do alto, novamente de um plongée, ela abaixo, agarrada à tábua, na superfície das águas, a cabeça inclinada, os cabelos escorridos sobre o rosto, reflexiva, os braços estendidos sobre a madeira. Estava “ pensando" tudo aquilo.

Aos poucos, os brilhos da luz sobre as águas começam a aumentar, sua superfície se movimenta, até que, por fusão sempre, a Mulher 1 desapareça, submersa no fundo do oceano.

No topo da colina, os urubus levantam vôo. Fica o vazio. Apenas a colina.

Podemos nos lembrar da Mulher 2.

Ficou o vazio.

Nesse momento, e nessa leitura, o que prevalece é a natureza realista do filme.

A Mulher 1, agarrada à tábua, instante antes de ser submergida sob a superfície das águas, é quem rememora o acontecido. Ela, a grande narradora intra-diegética do filme, a consciência pensante em seu fluxo interno. A omnisciência.

Seu Primeiro Plano, o olhar pensativo por trás dos cabelos molhados, é o tempo zero da narrativa, de onde tudo se origina.

A imagem alegórica que emoldura o filme, em fundo negro, apenas a projeção mental de seu interior.

A mulher pragmática, que não tem apego ao passado, subitamente, revela-se um ser sensível. Interiorizado.

Reluto em sair do universo do filme para lhe tecer comentários exteriores ao que esteja contido em seu próprio corpo, em sua própria contextura. Mas se quisermos mencionar o fato notório de que o filme se originou do impacto gerado por uma imagem na mente do autor, 
imagem essa que ele quis materializar na abertura e no fechamento do filme, tal como assaltou a mente de sua personagem, então, podemos dizer que a Mulher 1 é, inegavelmente, o seu alter ego.

\section{CONCLUSÃO}

Uma imagem é uma imagem, nos diz Godard. Ao que Eisenstein acrescentaria que as coisas não se passam na tela, mas na mente de quem vê. A associação é anacrônica pois, Godard vem dos anos sessenta. De qualquer modo, Limite parece, em sua fatura, responder bastante bem ao diálogo. Nele, poderosa é a montagem. e a construção do tempo.

Sua linguagem “memorialística”, à semelhança de Proust,, faz com que os eventos na tela sejam dados como coisas passadas, já idas. Portanto, o que restam são as imagens das coisas, e não elas em si.. Assim, cada uma delas, já surge impregnada pela sombra de sua morte futura, já sabida, acontecida num passado. De onde o tom de melancolia que emana do filme.

Em Limite, há momentos em que vemos as pessoas falando, à distância, no caso dos pescadores, seus lábios se movem, naturalmente, mas nós não as ouvimos. Se estão próximas, seus olhares são alheios aos nossos, oblíquos, interiorizados, para dentro. Seus lábios se movem, e não ouvimos. E não temos necessidade de sua fala.

Ao mesmo tempo, isso estabelece como que um véu que se interpõe entre nós e o objeto. Criase uma distância: as personagens estão lá, mas é como se não estivessem. Estavam. Uma distância no tempo, como se estivéssemos presenciando eventos já acontecidos. O tempo de Limite é no passado (26).Mas no pretérito imperfeito, não no perfeito. Não é no “aconteceu." Mas no "as coisas aconteciam assim naquele período...” Indefinidamente. E estariam, ainda, a ocorrer. Um tempo circular, um estado cíclico de suspensão.

A vida é composta de períodos que são transitórios e efêmeros. Fazem parte de um momento entre outros. São singulativos, únicos, porque só ocorrem por uma vez. Como ocorre no passado, são antes figuras do que humanos. São imagens, produto de uma imaginação. Como o próprio cinema.

Ao mesmo tempo, enquanto estilo, o filme é impuro. Vimos as variadas formas de representação de que ele se utiliza, que vai do construtivismo russo à vanguarda francesa e, ainda, o próprio naturalismo americano. É uma mistura de estilos que se ergue sobre uma estrutura rítmica.

Limite é um filme tardio, como se sabe: quando surge, o cinema já era sonoro e as possibilidades da estética cinematográfica já haviam se desenvolvido com força: o construtivismo russo, a vanguarda francesa e o expressionismo alemão, em particular. Formalmente, faz um diálogo 
com essas estéticas, que elaboram a questão da forma e não apenas do conteúdo. Mas seus experimentos de radicalização são a favor de uma elaboração narrativa, como vimos.

O curioso é o embate que o move: entre um impulso de romper, avançar, e outro de se defender, proteger. Há, no filme, como vimos, o confronto entre os dois tipos de olhares: um de um ponto de vista mais onisciente - o olhar do antigo, que quer dar conta do todo - e que, no filme, se realiza basicamente pelo uso do plongée - que é o que corresponde à grande estrutura de primeiro grau; e há o outro que responde a um ponto de vista mais "relativizado", parcial, que não quer dar conta do todo, mas ater-se àquilo que lhe corresponda enquanto experiência particular e individual de mundo, que é o "olhar moderno", e que é realizado pelas angulações, movimentos e montagem de livre arbítrio poético, como são, no caso das três outras estruturas de segundo grau gerados por ela. Desse embate é que se faz o filme.

Em 1965, no célebre texto, O cinema de poesia, Pasolini viria a formular: "Por baixo deste filme, corre o outro filme - o filme que o autor teria feito mesmo sem o pretexto da mímêsis visual do seu protagonista: um filme de carácter inteira e livremente expressivo-expressionista."

Tal parece ser uma formulação, tardia, que se aplica ao filme.

O trabalho apenas começa. Há um caminho a percorrer a partir dessas questões. E depois, - a se averiguar - a extrema aproximação de estilo que ele, pelo menos aparentemente, mantém com certos filmes posteriores, como, por exemplo, os de Antonioni, no tratamento do espaço, ou para ficarmos no período, com Murnau, no tratamento da paisagem, ou René Clair, Entre Act, 1927, especificamente (este último, por analogia e contraste).

No que se refere ao cinema brasileiro, filmes como Porto das Caixas, 1963, e A Casa Assassinada, 1969, ambos de Paulo César Saraceni, uma tendência que se difere de uma outra, igualmente rica, potente, mais evidente e ostensiva, talvez, que é a do realismo social.

Do mesmo filme, recupero a figura do Homem 1, caminhando de terno, chapéu e gravata pela estrada de terra. Essa figura que ganhou dimensão e foi assimilada, por um outro viés, em cineasta ligados, manifestadamente, ao cinema experimental no Brasil: Júlio Bressane, Rogério Sganzerla, João Silvério Trevisan, Luiz Rosemberg Filho, Andréa Tonacci e o próprio Glauber, de A Idade da Terra, 1977, para ficarmos com alguns. 


\section{REFERÊNCIAS BIBLIOGRÁFICAS}

ANDRADE, Mário de. A Escrava que não é Isaura. In: Obra Imatura. $3^{\mathrm{a}}$ ed. Belo Horizonte: Ed. Itatiaia, 1980. . A respeito de Mundéu. Revista Nova, São Paulo, ano I, 15 dez. 1931. In: Peixoto, Mário. Mundéu. 2a ed. Rio de Janeiro: Sette Letras, 1996. pp.9-12. . Aspectos da literatura brasileira. 6ª ed. São Paulo: Livraria Martins Editora, 1978. O Banquete. Belo Horizonte: Ed. Itatiaia, 2004. O Empalhador de Passarinho. Belo Horizonte: Ed. Itatiaia, 2002. O Turista Aprendiz. $2^{\text {a }}$ ed. São Paulo: Ed. Livraria Duas Cidades, 1983. Prefácio Interessantíssimo. In: Paulicéia Desvairada, Poesias Completas. 6 a ed. Belo Horizonte: Ed. Itatiaia, 1980.

ARGAN, Problemas fundamentais da estética. (cópia distribuída em curso).

BAZIN, André. O Cinema - Ensaios. Trad. Eloísa de Araújo Ribeiro. São Paulo: Brasiliense, 1991.

. O Cinema da Crueldade. Trad. Antonio de Pádua Danesi. São Paulo: Martins Fontes, 1989.

BENJAMIN, Walter. Charles Baudelaire, Um Lírico no Auge do Capitalismo. In: Obras Escolhidas III. trad. José Carlos Martins Barbosa e Hemerson Alves Baptista. $3^{\mathrm{a}}$ ed., $2^{\mathrm{a}}$ reimpressão. Rio de Janeiro: Brasiliense, 2000.

BERNARDET, Jean Claude. Brasil em Tempo de Cinema. Rio de Janeiro: Paz e Terra.

CÂNDIDO, Antonio. A revolução de 30 e a cultura. Em Novos Estudos. V.2. 4, p. 27-30, São Paulo: Cebrap, 1964. Literatura e sociedade. $5^{\text {a }}$ ed. São Paulo: Cia. Ed. Nacional, 1976.

CHARNEY, Leo; SCHWARTZ Vanessa R., O Cinema e a Invenção da Vida Moderna. org. trad. Regina Thompson, $2^{\mathrm{a}}$ ed. São Paulo: Cosac e Naify, 2004.

COURI, Norma. Mário Peixoto, uma história de fascínio sem limites. O Estado de S.Paulo, São Paulo, 31 jul. 1999. p. D6, Caderno 2.

DANTAS, Vinicius. Alma sem limite. Filme \& Cultura, Rio de Janeiro, n 43, Embrafilme, pp. 114-118, jan.-abr. 1984. In: Em Memória: base de dados sobre 15 cineastas brasileiros. São Paulo: Cinemateca Brasileira, 1996. (CD-ROM)

DEBRET, Jean Baptiste. Viagem pitoresca ai Brasil. Tomos 1 e 2. São Paulo: Livraria Martins, Ed. da USP, 1972.

GENETTE, Gerard. Discursos da Narrativa, Figuras III. Trad. Fernando Cabral Martins. Lisboa, Portugal: Assírio Bacelar, 1972.

GOMES, Paulo Emílio Salles. Cinema Brasileiro: Trajetória e Subdesenvolvimento. . Mauro e due altri grandi, Il cinema brasiliano, Genova, Silva, 1961, pp. 65-71; "Mauro et deux autres grands", positif n 314, Paris, abril 1987, pp. 40-43.

HOLLANDA, Sérgio Buarque. Raízes do Brasil. 21 a ed. Rio de Janeiro: José Olympio Editora, 1990. 
MACHADO JR, Rubens. Brésil: Les ombres oubliées d'un cinema inassouvi. L'Armateur, Paris, n³, pp. 43-46, set.-out. 1992.

. “Mário Peixoto”, Enciclopédia do Cinema Brasileiro, org. Luiz Felipe Miranda \& Fernão P. Ramos, São Paulo: SENAC, 2000, pp. 328-330.

. "Passos e descompassos à margem” in: Cinema Marginal e suas fronteiras: Filmes produzidos nas décadas de 60 e 70, orgs. E. Puppo \& V. Haddad, São Paulo: CCBB, 2001, pp. 16-19.

MÁRIO PEIXOTO: Limite (catálogo), texto de Saulo Pereira de Mello, Rio, MinC, Casa de Rui Barbosa, 1996, 48 p.

MELLO, Saulo Pereira de. Breve esboço de uma cinebiografia de Mário Peixoto. Mário Peixoto: Limite (catálogo). Rio de Janeiro, MinC, Casa de Rui Barbosa, 1996. pp. 4-45.

. História da produção de Limite. In: Estudos sobre LIMITE. Rio de Janeiro: LIA-UFF (Laboratório de Investigação Audiovisual da Universidade Federal Fluminense), 1998. (CD-ROM) . Limite - filme de Mário Peixoto. Rio de Janeiro: Ed. Inelivro, Funarte, 1979. . Limite. Rio de Janeiro: Rocco (Artemídia), 1996. 115 p.

MORAES, Marcos Antonio (org.). Correspondência: Mário de Andrade e Manuel Bandeira. $2^{\mathrm{a}}$ ed. São Paulo: Edusp, 2001.

MORAES, Vinicius de. Exibição de Limite (1942). O cinema de meus olhos. org. intr. Carlos Augusto Calil. São Paulo: Companhia das Letras, Cinemateca Brasileira, 1991. pp. 7072.

Limite. A Manhã, circa 1941-1942. In: Filme Cultura, Rio de Janeiro, $\mathrm{n}^{\circ} 28$, Embrafilme, pp. 85-86, fev. 1978. In: Em Memória: base de dados sobre 15 cineastas brasileiros. São Paulo: Cinemateca Brasileira, 1996. (CD-ROM)

NAVES, Rodrigo. A Forma Difícil. 2ª ed. São Paulo: Ática, 2001.

O FAN. (Revista) 7 exemplares. Rio de Janeiro, 1928.

PASOLINI, Píer Paolo. O Empirismo Herege. Trad. Miguel Serras Pereira. Lisboa, Portugal: Assírio e Alvim, 1982.

PEIXOTO, Mário. A Alma Segundo Salustre ("scenario"). Rio de Janeiro: Embrafilme, 1983. $100 \mathrm{p}$.

. A Alma Segundo Salustre. Rio de Janeiro: Embrafilme, 1983.

. Diretor de Limite diz que cinema brasileiro tem potencial. Entrevista a Maurício Stycer. Folha de S.Paulo, São Paulo, 29 set. 1988. p. 3, Ilustrada. In: Em Memória: base de dados sobre 15 cineastas brasileiros. São Paulo: Cinemateca Brasileira, 1996. (CDROM) 210 p.

. Limite (fotogramas). Texto de Saulo Pereira de Mello. Rio de Janeiro: Funarte, 1978. . Limite. Rio de Janeiro: Sette Letras, 1996.

. Limite: "scenario" original. Rio de Janeiro: Sette Letras, Arquivo Mário Peixoto, 1996. $143 \mathrm{p}$. 
. Mundéu (poemas). $2^{\mathrm{a}}$ ed. Rio de Janeiro: Sette Letras, 1996. 99 p.

. O cinema caluniado. O Jornal. 6 maio 1937. In: Em Memória: base de dados sobre

15 cineastas brasileiros. São Paulo: Cinemateca Brasileira, 1996. (CD-ROM)

. O inútil de cada um (romance). $2^{\mathrm{a}}$ ed. Rio de Janeiro: Sette Letras, 1996. 155 p.

. O inútil de cada um. vol. 1 (da versão ampliada do romance). Rio de Janeiro: Record, 1984.

. Outono: o jardim petrificado. Rio de Janeiro: Aeroplano, 2001.

. Seis contos e duas peças curtas. Rio de Janeiro: Aeroplano, 2004.

PRADO, Paulo. Retrato do Brasil. 8ª ed. São Paulo: Cia das Letras, 1997.

ROCHA, Glauber. O Mito 'Limite'. Revisão crítica do cinema brasileiro. Rio de Janeiro: Civilização Brasileira, 1963. pp. 33-45.

."Limite". Folha de S. Paulo, 03 jun. 1978. Hemeroteca Cinemateca Brasileira, 595/15.

Revisão Crítica do Cinema Brasileiro. Rio de Janeiro: Civilização Brasileira, 1963.

ROCHA, Plínio Süssekind. Limite. Entrevista a Paulo Emílio Salles Gomes originalmente publicada em L'Âge du Cinema. Revista Cineclube. Federação dos Cineclubes do Rio de Janeiro, ano I, n 1 , III trim. 1960; rep. in: Em Memória: base de dados sobre 15 cineastas brasileiros. São Paulo: Cinemateca Brasileira, 1996. (CD-ROM)

RODAPÉ. Critica de literatura brasileira contemporânea. Debate “Crítica de Intervenção”. São Paulo: Nankin Editorial, 2004.

ROIZMAN, Geraldo Blay. Mário Peixoto, Um Olhar Fenomenológico, Mestrado em Artes Visuais, orientação de Francisco Alambert Jr., IA-UNESP, Universidade Estadual Paulista Júlio de Mesquita Filho, 2003.

SCHWARZ, Roberto. Nacional por subtração. em Que horas são?. São Paulo: Cia das Letras, 1987.

. Seqüências brasileiras. São Paulo: Cia das Letras, 1999.

TARKOVSKY, Andrey. Esculpir o Tempo. Trad. Jefferson Luis Camargo. São Paulo: Martins Fontes, 1990.

. Time within Time - the diaries 1970-1986. Trad. Kitty Hunter. London, Boston:

Faber and Faber, 1994.

TEIXEIRA, Francisco Elinaldo. O terceiro olho: ensaios de cinema e vídeo (Mário Peixoto, Glauber Rocha e Júlio Bressane), São Paulo: Perspectiva (Estudos), 2003, 161 p.

TOCANTINS, Leandro. O Limite do Mito. Filme Cultura, n 31, pp. 78-85, nov. 1978.

VIEIRA, João Luiz. A chanchada e o cinema carioca (1930-1955). In: Ramos, F. (org.). História do cinema brasileiro. São Paulo: Art, 1987. pp. 137-139.

WEISS, Peter. Peixoto: Limite. Cinéma d'avant-garde, Paris: L'Arche, 1989.

WOOLF, Virginia. The Waves. Londres, 1926.

XAVIER, Ismail (org.) .A Experiência do Cinema. Rio de Janeiro: Edições Graal, Embrafilme, 1983. 
Alegorias do Subdesenvolvimento: Cinema Novo, Tropicalismo,Cinema Marginal. São Paulo: Brasiliense, 1993.

. Sétima arte: um culto moderno. São Paulo: Perspectiva, 1978.

.O Discurso Cinematográfico: a Opacidade e a Transparência. Rio de Janeiro: Paz e Terra, 1977.

Filmografia

LIMITE (RJ, 1931, pb, LM). Cia produtora: Mario Peixoto (produtor);

Direção/argumento/roteiro: Mario Peixoto; Montagem: Edgar Brasil, Mario Peixoto; Dir. fotografia: Edgar Brasil; Elenco: Raul Schnoor, Olga Breno, Taciana Rei, D. G. Pedrera, Mario Peixoto.

O HOMEM E O MORCEGO (RJ, MM). Dir: Ruy Santos.

ONDE A TERRA ACABA (RJ, 2002, corxpb, LM). Dir: Sérgio Machado. 